SARJA - SER. D OSA - TOM. 954

MEDICA - ODONTOLOGICA

\title{
AUTOLOGOUS STEM CELL TRANSPLANTATION IN MULTIPLE MYELOMA
}

by

Mervi Putkonen 
From the Department of Medicine

University of Turku, Finland

\section{Supervised by}

Professor Kari Remes, MD, PhD

Department of Medicine, Division of Hematological Diseases University of Turku

Turku, Finland

and

Docent Maija Itälä-Remes, MD, PhD

Department of Medicine, Division of Hematological Diseases

University of Turku

Turku, Finland

\section{Reviewed by}

Docent Marjaana Säily, MD, PhD

Department of Medicine, Division of Hematological Diseases University of Oulu

Oulu, Finland

and

Professor Anders Waage

Department of Hematology

University of Trondheim

Trondheim, Norge

\section{Dissertation opponent}

Professor Kimmo Porkka, MD, PhD Hematology Research Unit Helsinki

Department of Medicine, Division of Hematolology University of Helsinki

Helsinki, Finland

ISBN 978-951-29-4559-7 (PRINT)

ISBN 978-951-29-4560-3 (PDF)

ISSN 0355-9483

Painosalama Oy - Turku, Finland 2011 
To my men 


\section{ABSTRACT}

\section{Mervi Putkonen}

\section{Autologous Stem Cell Transplantation In Multiple Myeloma}

From the Department of Medicine, University of Turku, Finland

Annales Universitatis Turkuensis

Painosalama Oy - Turku, Finland 2011

Background. Multiple myeloma (MM) is the second most common hematologic malignancy after lymphomas In Finland: the annual incidence of MM is approximately 200. For three decades the median survival remained at 3 to 4 years from diagnosis until high-dose melphalan treatment supported by autologous stem cell transplantation (ASCT) became the standard of care for newly diagnosed MM since the mid 1990's and the median survival increased to 5-6 years. This study focuses on three important aspects of ASCT, namely 1) stem cell mobilization, 2) single vs. double ASCT as initial treatment, and 3 ) the role of minimal residual disease (MRD) for longterm outcome.

Aim. The aim of this series of studies was to evaluate the outcomes of MM patients and the ASCT procedure at the Turku University Central Hospital, Finland. First, we tried to identify which factors predict unsuccessful mobilization of autologous stem cells. Second, we compared the use of short-acting granulocyte-colony stimulating factor (GCSF) with long-acting G-CSF as mobilization agents. Third, one and two successive ASCTs were compared in 100 patients with MM. Fourth, for patients in complete response (CR) after stem cell transplantation (SCT), patient-specific probes for quantitative allele-specific oligonucleotide polymerase-chain reaction (qASO-PCR) measurements were designed to evaluate MRD and its importance for long-term outcome.

Results. The quantity of previous chemotherapy and previous interferon use were significant pre-mobilization factors that predicted mobilization failure, together with some factors related to mobilization therapy itself, such as duration and degree of cytopenias and occurrence of sepsis. Short-acting and long-acting G-CSF combined with chemotherapy were comparable as stem cells mobilizers. The progression free (PFS) and overall survival (OS) tended to be longer after double ASCT than after single ASCT with a median follow-up time of 4 years, but this difference disappeared as the follow-up time increased. qASO-PCR was a good and sensitive divider of the CR patients into two prognostic groups: MRD low/negative $(\leq 0.01 \%)$ and MRD high $(>0.01 \%)$ groups with a significant difference in PFS and suggestively also in OS.

Conclusions. When the factors prediciting a poor outcome of stem cell mobilization prevail, it is possible to identify those patients who need specific efforts to maximize the mobilization efficacy. Long-acting pegfilgrastim is a practical and effective alternative to short-acting filgrastim for mobilization therapy. There is no need to perform double ASCT on all eligible patients. MRD assessment with qASO-PCR is a sensitive method for evaluation of the depth of the CR response and can be used to predict long-term outcome after ACST.

Keyword: Autologous stem cell transplantation, mobilization, MRD, qASO-PCR 


\section{TIIVISTELMÄ}

\section{Mervi Putkonen}

\section{Autologiset kantasolujen siirrot multippelissa myeloomassa}

Sisätautien klinikka, Turun yliopistollinen keskussairaala, Turun yliopisto, Suomi

Turun yliopiston julkaisuja

Painosalama Oy - Turku, 2011

Tausta. Multippeli myelooma (MM) on pahanlaatuinen veritauti. Lähes 30 vuoden ajan MM:n ennuste pysyi samana eli odotettavissa oleva elinaika diagnoosista lukien 3-4 vuotena, kunnes 1990-luvun puolivälistä lähtien käyttöön tullut suuriannoksinen hoito omien kantasolujen siirron tukemana pidensi sen 5-6 vuoteen. Autologinen kantasolujen siirto (ASCT) korkea-annoshoitoon yhdistettynä onkin uuden MM potilaan standardi hoito. ASCT:n edellytys on, että riittävä määrä kantasoluja saadaan kerätyksi. Kantasolut kerätään verestä mobilisaatiohoidon jälkeen. Keruu ei aina onnistu. Itse kantasolujensiirron toteutuksessa on avoin kysymys, voidaanko kahdella peräkkäisellä ASCT:lla parantaa hoitotuloksia yhteen siirtoon verrattuna. MM:n hoidon nykytavoitteena on täydellinen hoitovaste ja jäännöstaudin määrällä voi olla merkitystä pitkäaikaistuloksille.

Tavoitteet. Tämä tutkimuskokonaisuus koostuu neljästä osatyöstä, joissa selvitettiin TYKS:ssa ASCT:Ila hoidettujen MM potilaiden hoitotuloksia. Tutkimus keskittyy kolmeen aihepiiriin: 1) mobilisaatiohoitoon, ja sen kahteen erityiskysymykseen: mitkä tekijät ennustavat kantasolujen mobilisaation epäonnistumista ja ovatko pitkä- ja lyhytvaikutteinen valkosolukasvutekijä vertailukelpoisia mobilisaatiossa, 2) yhden ja kahden peräkkäisen ASCT:n hoitotulosten vertailuun sekä 3) täydellisen hoitovasteen saaneiden potilaiden vasteen laadun ja sen merkityksen selvittelyyn tutkimalla jäännöstautia herkällä potilaskohtaisella PCR-menetelmällä.

Tulokset. Kantasolujen mobilisaation epäonnistumista ennakoiviksi tekijöiksi osoittautuivat aiemmin saadun solunsalpaajahoidon määrä, aiempi interferonihoito sekä mobilisaatiohoitoon liittyvät sytopeniat, niiden kesto ja sepsis (osajulkaisu I). Kasvutekijän vertailussa pitkävaikutteinen pegfilgrastiimi ja lyhytvaikutteinen filgrastiimi olivat yhtä tehokkaita kantasolujen mobilisoinnissa (osajulkaisu II). Kaksi peräkkäistä ASCT:a johtivat neljän vuoden seurannassa parempiin pitkäaikaistuloksiin kuin yksi ASCT (osajulkaisu III), mutta pidennetyssä seurannassa erot hävisivät. Herkkä potilaskohtainen PCR-menetelmä osoitti, että molekulaarinen hoitovaste on yleisempi allogeenisen kuin autologisen kantasolusiirron jälkeen. Niillä, joilla jäännöstauti hävisi tai sitä oli vain vähän $(\leq 0.01 \%)$, tauditon aika ja kokonaiselinaika olivat merkittävästi pidemmät kuin niillä, joilla oli enemmän jäännöstautia (>0.01\%).

Johtopäätökset. Kantasolujen mobilisaation epäonnistumista ennakoivat tekijät auttavat tunnistamaan ne potilaat, jotka vaativat erityistoimia mobilisaation onnistumiseksi. Pegfilgrastiimi on käyttökelpoinen ja kätevä kasvutekijä kantasolujen mobilisaatiossa. Koska yhden ja kahden peräkkäisen kantasolusiirron tulokset eivät pitkässä seurannassa merkittävästi eroa, kahta peräkkäistä ASCT:ta ei ole syytä käyttää kaikille potilaille. Molekulaarinen remissio johtaa parempiin pitkäaikaistuloksiin kuin jäännöstautinen remissio ja on looginen hoidon tavoite. Sen arvioimiseen on tarjolla herkkä kvantitatiivinen, potilaskohtainen PCR-menetelmä.

Avainsanat: Autologinen kantasolujen siirto, mobilisaatio, jäännöstauti, PCR 


\section{TABLE OF CONTENTS}

ABSTRACT

TIIVISTELMÄ

TABLE OF CONTENTS

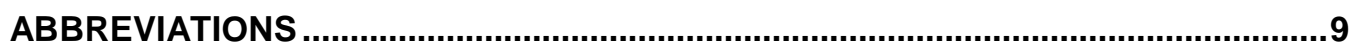

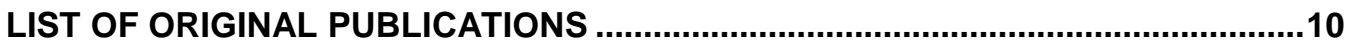

1. INTRODUCTION

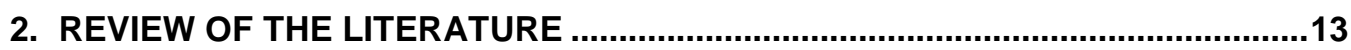

2.1 Epidemiology and incidence of multiple myeloma .......................................13

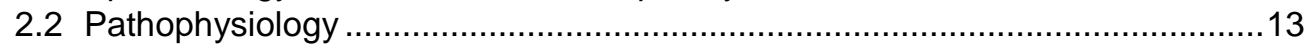

2.2.1 Cytogenetics and gene expression .................................................14

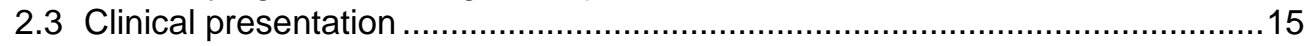

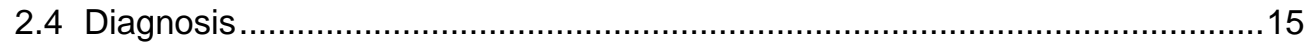

2.4.1 Immunophenotype of multiple myeloma ……….............................17

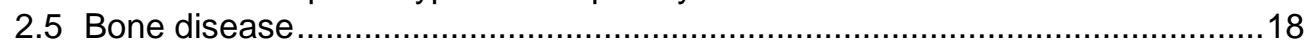

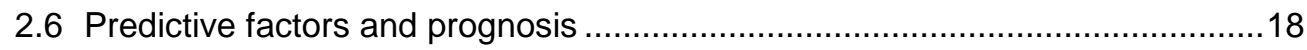

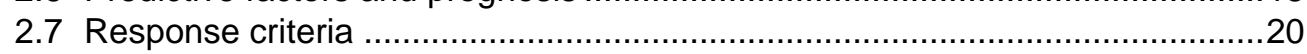

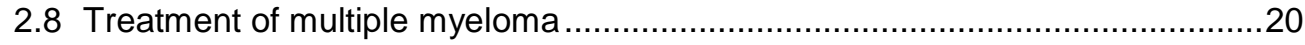

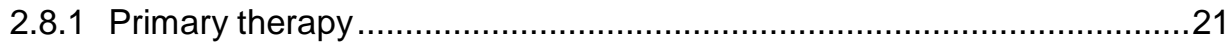

2.8.1.1 Drug therapy .................................................................21

2.8.1.1.1 First-line treatment of patients eligible and ineligible for transplantation .....................................21

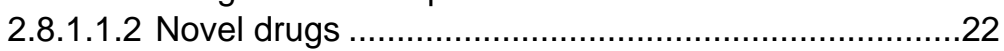

2.8.1.2 Autologous stem cell transplantation ......................................23

2.8.1.3 Tandem autologous transplantation .....................................24

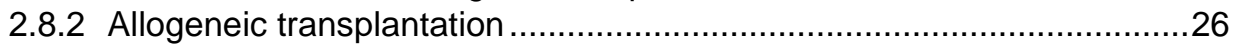

2.8.2.1 Tandem autologous plus allogeneic transplantation ................26

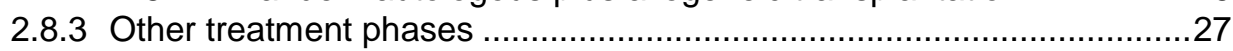

2.8.3.1 Advanced disease phases.....................................................27

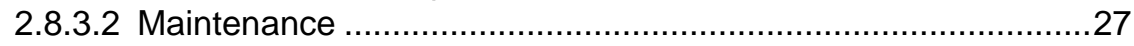

2.8.4 Importance of complete response and molecular response ..................28

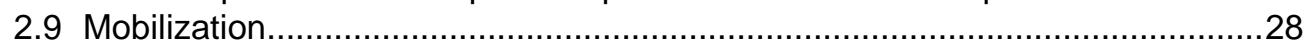

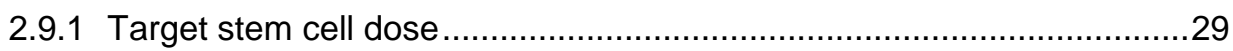

2.9.2 Biology of stem cell mobilization ......................................................29

2.9.3 Stem cell collection ...................................................................

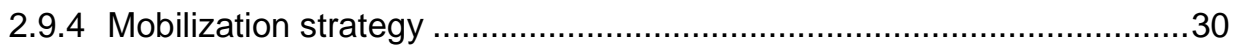

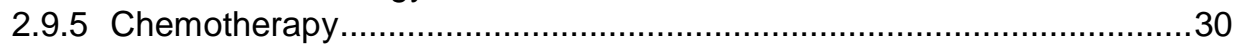

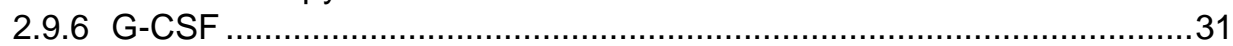

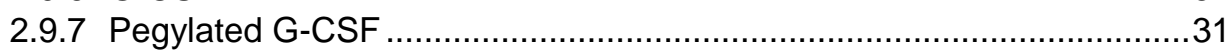

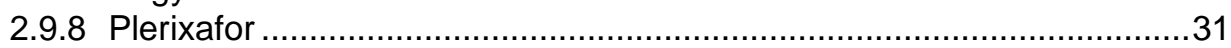




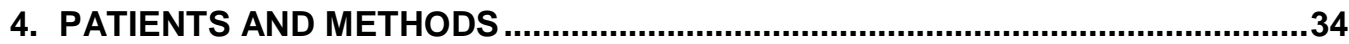

4.1 Patients and data collection (I-IV) ..................................................... 34

4.2 Stem cell mobilization: Predictive factors for mobilization failure and

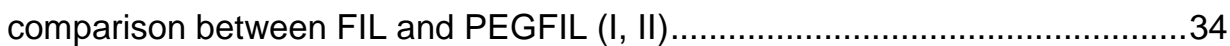

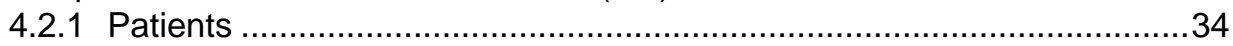

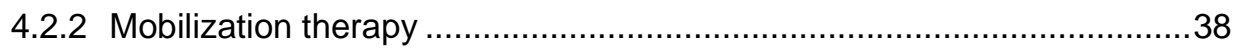

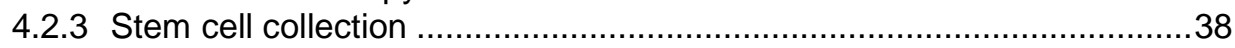

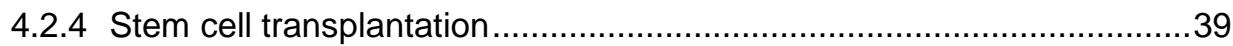

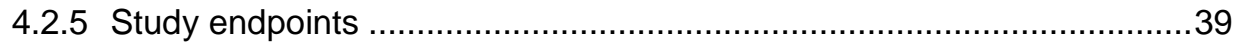

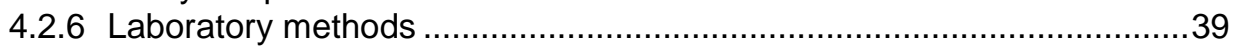

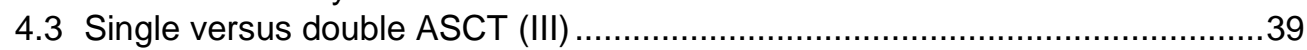

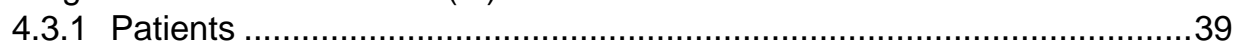

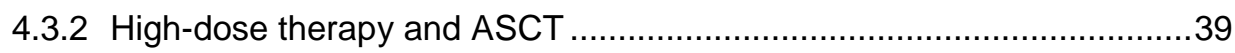

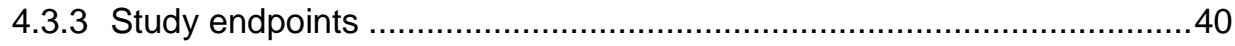

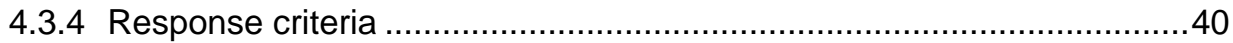

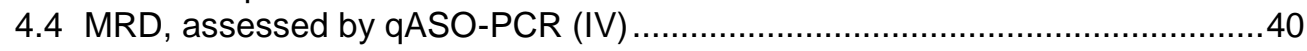

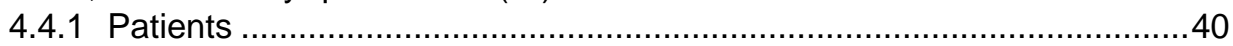

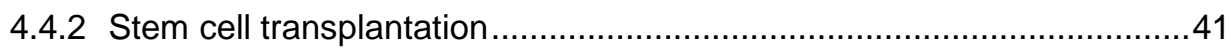

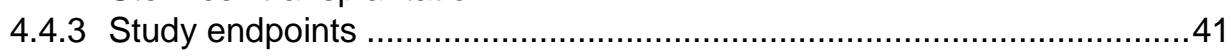

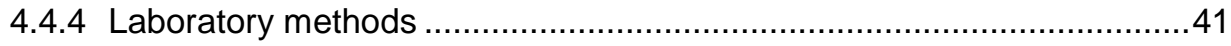

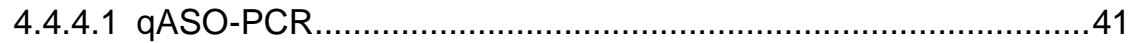

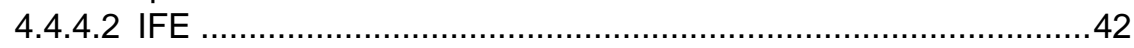

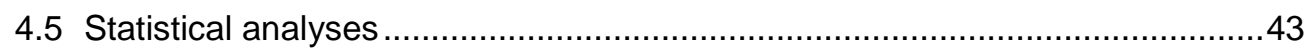

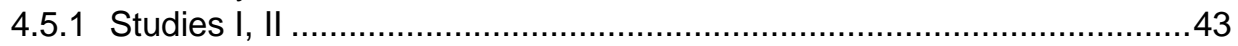

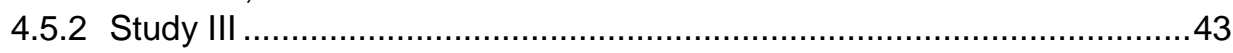

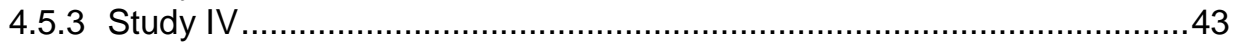

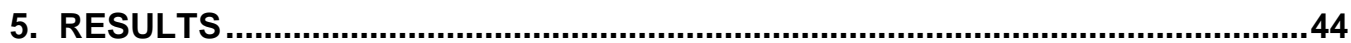

5.1 Prediction of mobilization failure $(\mathrm{I})$...................................................... 44

5.1.1 Predictive factors for successful CD34+ cell mobilization......................44

5.2 Comparison of short-acting and long-acting G-CSF as mobilizing agents in combination with chemotherapy in patients with lymphoproliferative

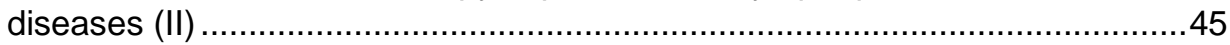

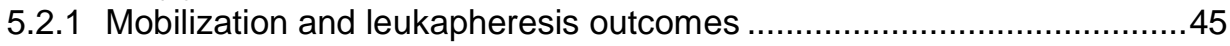

5.2 .2 High-dose therapy and autografting .............................................. 46

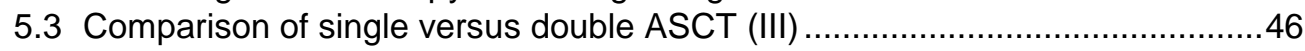

5.3.1 Feasibility of double ASCT .........................................................46

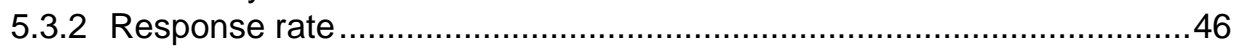

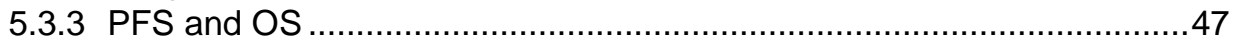

5.4 MRD status after SCT, assessed by qASO-PCR (IV) ...............................50

5.4.1 PCR negativity after autologous and allogeneic SCT .........................50

5.4 .2 Impact of MRD status on PFS and OS ........................................50

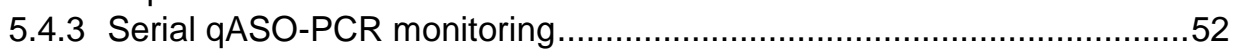

5.4 .4 qASO-PCR vs IFE in MRD assessment ..................................... 52 


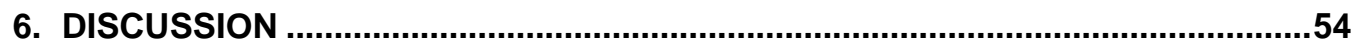

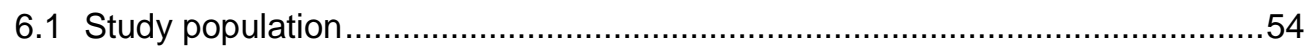

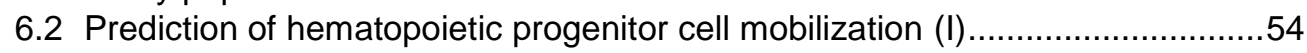

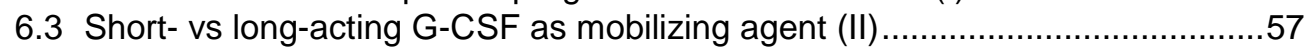

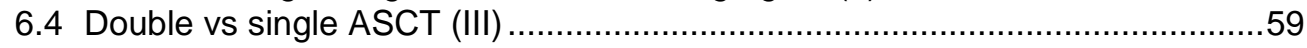

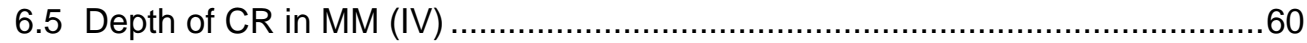

6.5.1 Use of qASO-PCR for MRD assessment............................................61

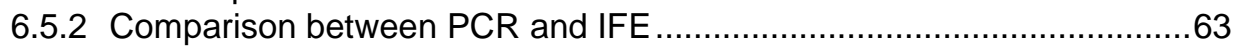

6.5.3 Comparison between PCR and flow cytometry .............................63

7. SUMMARY AND CONCLUSIONS....................................................................65

7.1 The predictive factors of stem cell mobilization failure ..................................65

7.2 Short-acting or long acting G-CSF for mobilization? ..................................65

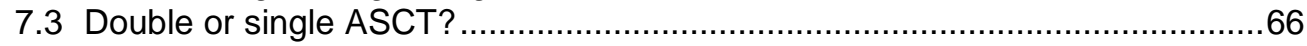

7.4 Importance of depth of complete response after stem cell transplantation ......66

8. ACKNOWLEDGEMENTS ............................................................................68

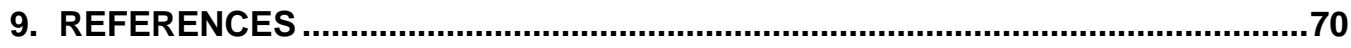

ORIGINAL PUBLICATIONS ..................................................................................89 


\section{ABBREVIATIONS}

alloSCT allogeneic stem cell
transplantation

ASCT autologous stem cell transplantation

ASO allele-specific oligonucleotide

ATG anti-thymocyte globulin

BM bone marrow

CR complete response

CXCR4 C-X-C chemokine receptor type 4

CY cyclophosphamide

DFS disease free survival

DLI donor lymphocyte infusion

EBMT European Group for Blood and Marrow Transplantation

EFS event free survival

EMEA European Medicines Agency

FIL filgrastim

FISH fluorescent in-situ hybridisation

FLC free light chains

G-CSF granulocyte-colony stimulating factor

GvMM graft versus myeloma

HDM high-dose melphalan

HDT high-dose treatment

IBMTR International Bone Marrow

Transplant Registry

IFE immunofixation

IFM Intergroupe Francophone du Myélome

IFN interferon $\alpha$

Ig immunoglobulin $\lg \mathrm{H} \quad$ immunoglobulin heavy-chain

ISS International Staging System

MGUS monoclonal gammopathy of undetermined significance

MM multiple myeloma

MP melphalan- prednisone

MPT melphalan-prednisonethalidomide

MRD minimal residual disease

nCR near to complete remisson

OS overall survival

PCR polymerase chain reaction

PD progressive disease

PEGFIL pegfilgrastim

PFS progression free survival

PR partial response

qASO quantitative allele-specific oligonucleotides

RANKL receptor activator of nuclear factor $K ß$ ligand

RIC-allo allogeneic transplantation with reduced-intensity conditioning

SCT stem cell transplantation

SD stable disease

SDF-1 stromal cell-deprived factor 1

TBI total body irradiation

TRM treatment related mortality

VAD vincristine- adriamycindexamethasone

VGPR very good partial remission 


\section{LIST OF ORIGINAL PUBLICATIONS}

This thesis is based on the following publications, which are referred to in the text by the Roman numerals I-IV.

I Putkonen M, Rauhala A, Pelliniemi T-T, Remes K. Sepsis, low platelet nadir at mobilization and previous IFN use predict stem cell mobilization failure in patients with multiple myeloma. Cytotherapy 2007;9:548-554.

II Putkonen M, Rauhala A, Pelliniemi T-T, Remes K. Single-dose pegfilgrastim is comparable to daily filgrastim in mobilizing peripheral blood stem cells: a casematched study in patients with lymphoproliferative malignancies. Ann Hematol 2009;88:673-680.

III Putkonen M, Rauhala A, Itälä M, Kauppila M, Pelliniemi T-T, Remes K. Double versus single autotransplantation in multiple myeloma, a single center experience of 100 patients. Hematol / Hematol J 2005;90:562-563.

IV Putkonen M, Kairisto V, Juvonen V, Pelliniemi T-T, Rauhala A, Itälä-Remes M, Remes K. Depth of response assessed by quantitative ASO-PCR predicts the outcome after stem cell transplantation in multiple myeloma. Eur $\mathrm{J}$ Haematol 2010; 85: 416-423.

The orginal papers in this thesis have been reproduced with permission of the copyright holders. 


\section{INTRODUCTION}

Multiple myeloma (MM) is a malignant plasma cell disease. The cardinal presenting symptoms of MM are anemia, renal failure, hypercalcemia and painful bone disease. In the late 1950's the first effective drug, melphalan was introduced (Bergsagel et al. 1962) and later in the 1960's it was combined with prednisone (MP; Alexanian et al. 1972). The prognosis of MM was, however, dismal: the median survival was 3 to 4 years and there were no improvements in survival during the next three decades in spite of numerous chemotherapeutic treatment attempts - there were no winners over and above the classical MP combination (Myeloma Trialists' Collaborative Group 1998). In the early 1980's the efficacy of high-dose melphalan was demonstrated (McElwain and Powles 1983) and this was the basis for the increasing use of high-dose melphalan therapy for MM. Since the mid 1990's the use of high-dose melphalan (HDM) followed by infusion of autologous stem cells, i.e. autologous stem cell transplantation (ASCT), has become the standard of care for patients with newly diagnosed $\mathrm{MM}$ and this treatment modality has prolonged the median survival of patients with MM to $5-6$ years (Cunningham et al. 1994, Attal et al. 1996, Palumbo et al. 1999, Lenhoff et al. 2000, Barlogie et al. 2007).

The prerequisite for ASCT is successful collection of autologous stem cells. For this purpose, the stem cells must be mobilized from bone marrow into the circulating blood. Then they can be collected by cytapheresis in an amount sufficient for repopulation of the bone marrow which has suffered from myeloablative HDM treatment. During the early years of ASCT the sufficient amount of stem cells (or CD34+ cells which reflect the population of stem cells plus progenitor cells) needed to allow regeneration of bone marrow cell lineages was found to be $2.5-4.0 \times 10^{6} / \mathrm{kg}$ (Gandhi et al. 1999, Fu and Liesveld, 2000). Successful CD34+ cell harvesting can be predicted from the concentration of CD34+ cells in blood mobilized with chemotherapy in combination with granulocyte colony-stimulating factor (G-CSF) or G-CSF alone (Haas et al. 1994, Remes et al. 1997). There are, however, patients for whom mobilization fails and ASCT cannot be used for these patients, which leaves out an effective treatment option. Some predictive factors for mobilization failure have been identified but failure or success of mobilization cannot be foreseen.

One single HDM followed by ASCT is the standard of care for a newly diagnosed patient with MM. The next logical step was that, in chemosensitive disease, the more is better, i.e. two sequential HDM's could be more effective than one. This has been studied but results have been conflicting and the question remains if double ASCT is better than single ASCT or not.

Complete response (CR) and preferably high quality $\mathrm{CR}$ to initial therapy is an absolute prerequisite for cure of acute leukemias. Thus, patients who attain a complete molecular response do better in terms of relapse risk. Recent progress in the treatment of MM has introduced treatment modalities, such as allogeneic and autologous SCT and novel drugs, which produce CR much more often than before. In analogy with acute leukemias, there are studies suggesting, but not proving, that the depth of CR is decisive for long-term outcome: patients without minimal residual disease (MRD) do better in long-term than patients with MRD (Corradini et al. 2003, Bakkus et al. 2004, Rasmussen et al. 2004). This statement needs to be confirmed by future studies. 
This series of studies is focused on three important issues in the field of MM treatment with ASCT: stem cell mobilization, double versus single ASCT and the importance of MRD after stem cell transplantation. The study cohort consisted of patients with newly diagnosed MM treated at the Univeristy Central Hospital of Turku. First, we examined factors which predicted stem cell mobilization failure and compared long-acting G-CSF with short-acting G-CSF as a mobilizing agent. Secondly, we compared the clinical outcomes between the double and single ASCT. Thirdly, we studied the MRD status of MM patients after autologous or allogeneic SCT and the impact of MRD on long-term outcome. 


\section{REVIEW OF THE LITERATURE}

\subsection{Epidemiology and incidence of multiple myeloma}

MM has probably existed among the human diseases for thousands of years. In 1844 Solly described the first well-documented case: A 39-year old woman had fatigue and bone pain caused by multiple fractures (Solly 1844).

MM is nowadays the second most common hematologic malignancy and the most common plasma cell neoplasm. Plasma cell disorders are characterized by secretion of monoclonal proteins or immunoglobulins ( $M$ protein or paraprotein) by the malignant plasma cells into the blood and/or urine. MM accounts for approximately $1 \%$ of all cancers and for $10-15 \%$ of all malignant hematologic diseases. It has an annual incidence of $4-5$ per 100000 (Turesson et al. 1984, Phekoo et al. 2004). MM is slightly more common in males than females and twice as common in blacks than whites.

MM evolves from an asymptomatic premalignant stage of clonal plasma cell proliferation termed monoclonal gammopathy of undetermined significance (MGUS; Landgren 2009). MGUS is present in more than $3 \%$ of the population above the age of 50 and progresses to myeloma at a rate of $1 \%$ per year (Kyle et al. 2003b, Landgren 2009).

An increased incidence of $\mathrm{MM}$ has been associated with chronic antigenic stimulation by infection or other disease and exposure to specific toxic substances or radiation, but most patients have no identifiable cause (McKenna et al. 2008). The role of genetic background or environment are unknown, although there is evidence for some clustering within families. The risk of MM is 3.7 fold for individuals who have a first degree relative with MM (McKenna et al. 2008).

The median age of the patients at presentation of MM is about 70 years worldwide and 72 in Europe (Ludvig et al. 1982). At diagnosis, approximately $15 \%$ of the patients are aged under 60 years and fewer than $2 \%$ of patients are under 40 years and $15 \%$ of patients are aged between 60 and 65 years old. The annual incidence of MM in Finland is about 200. In $2004-200820 \%$ of the patients were under 60 years and $40 \%$ were over 70 years of age at the time of diagnosis (www.cancerregistry.fi).

\subsection{Pathophysiology}

The basic understanding of the pathophysiology of $\mathrm{MM}$ has increased substantially during the last decade, but it is still insufficient and at present only fragments of it are known. There may be several molecular and pathopysiological events leading to the MM phenotype.

The first sign in the development of $\mathrm{MM}$ is the appearance of a limited number of clonal plasma cells, clinically known as MGUS. When MGUS progresses to MM, complex genetic events occur in the neoplastic plasma cells. The bone marrow 
microenvironment plays an essential role in disease maintenance and progression. Interactions with other cells and the extracellular matrix (fibrous proteins, proteoglycans, glycosaminoglycans and small integrin-binding ligands) within the bone marrow (BM) environment are key elements for MM pathogenesis, MM cell growth, survival, migration and drug resistance (Raab et al. 2009, Balakumaran et al. 2010). Cytokines and growth factors are produced and secreted by MM and other cells within the liquid compartment of marrow and regulated both by autocrine as well as paracrine loops and cell-to-cell adhesion (Rajkumar et al. 2002, Roodman 2002).

Plasma cell neoplasms can be distinguished by an idiotypic rearrangement of the immunoglobulin $(\mathrm{lg})$ gene. That occurs prior to the malignant transformation of a plasma cell precursor. The size of the developing clone must increase up to $5 \times 10^{9}$ cells before a monoclonal spike can be recognized in the serum electrophoresis pattern (Katzmann et al, 2010).

The molecular basis of MM is still elusive despite the increased understanding of biology in this disease. The target cell for transformation has supposed to be a more immature B cell than plasma cell (Bakkus et al. 1995). The initial transformation is postulated to occur in postgerminal center B-lineage cell which is carrying a somatically hypermutated immunoglobulin heavy -chain $(\mathrm{lgH})$ gene. This plasmablastic precursor cell colonises the BM, propagates clonally and differentiates into a slowly proliferating $\mathrm{MM}$ cell population. This all happens under the influence of specific cell adhesion molecules and cytokines. The essential element of MM cell growth is the production of interleukin-6 (IL-6) by stromal cells, osteoblasts and neoplastic cells (Kastrinakis et al. 2000). Binding of the cytokine to its receptor triggers MM cell immortalisation and/or proliferation through utilisation of the Jak-Stat and ras signal transduction pathways (Hawley and Berger 1998, Mitsiades et al. 2007).

\subsubsection{Cytogenetics and gene expression}

Genetic events appear to play the key role in initiation and progression of MM. Many studies, in which karyotyping has been performed, have shown the prognostic value of cytogenetic abnormalities (Rajkumar et al. 1997, Ross et al. 2005). Cytogenetic abnormalities are propably present in most, if not all patients with MM if sufficiently sensitive techniques are used, e.g. interphase fluorescent in-situ hybridisation (FISH; Fonseca et al. 2006).

Complex cytogenetic abnormalities are common in MM. Numeric abnormalities occur in the genes in both a non-hyperdiploid (about half of the cases) and a hyperdiploid (another half of the cases) pattern. Hyperdiploid abnormalities are caused by multiple trisomias, mainly in the odd numbered chromosomes $3,5,7,9,11,15,19,21$, and are associated with more favourable outcome (Fonseca et al. 2004 and 2009, Dewald et al. 2005). On the contrary, non-hyperdiploid abnormalities are associated with shortened survival due to high-risk translocations, partial or complete loss of chromosome 13, and partial loss of chromosome 17 (Raab et al. 2009). About half of the patients have translocations that involve the $\mathrm{IgH}$ locus on chromosome $14 \mathrm{q} 32$ and one of five partner chromosomes: 11q13 (the most common), 6p21, 16q23, 4p16, and 20 q11 (Kuehl and Bergsagel 2002, Seidl et al. 2003). The respective oncogens juxtaposed to lgH locus are CCND1 (cyclin D1), CCND3 (cyclin D3), MAF, FGFR/MMSET, and MAFB. These five oncogenes are found in $40 \%$ of non-hyperdiploid MM. In all, the most common 
cytogenetic changes are chromosome 13 deletion (30-55 \% of MM patients), deletion 17p13.1 (10\%), t (11;14) (q13;q32) (15-20\%), t (4;14) (p16.3; q32) (15\%) and $t(14 ; 16)$ (q32;q23) (5\%) (Fonseca et al. 2004). Translocations $(11 ; 14)$ and $(6 ; 14)$ are associated with a better outcome (Fonseca et al. 2004, Dewald et al. 2005).

Gene expression profiling can determine the expression levels of cyclin D1, D2 and D3. Using patterns of translocation and cyclin D expression MM can be classified into eight groups that are based on initiating or early pathogenic events. These different groups may represent distinct $\mathrm{MM}$ entities and probably require different therapeutic approaches (Bergsagel et al. 2005).

From the clinical point of view, it has become apparent that hypodiploidy is a major adverse prognostic factor (Debes-Marun et al. 2003). Similarly, certain recurrent cytogenetic abnormalities define a poor prognosis after SCT, including $t(4 ; 14), t(14: 16)$, del 13, del 17p-, and abnormalities of chromosome 1 (1 q+ and 1 p-). However, patients with an isolated del 13 detected in FISH seem not to have a less favourable outcome unless the deletion is found also in normal karyotype analysis. This is because the poor prognosis of del 13 detected by FISH appears to be almost fully related to the coexisting IgH translocations such as $\mathrm{t}(4 ; 14)$ (Rajkumar et al. 2007a).

\subsection{Clinical presentation}

The clinical presentation of MM is varying. The most common presenting symptoms are bone pain, fatigue and recurrent or persistent infections (Kyle et al. 2003a). Nearly half of the patients have bone pain at presentation. Bone pain is typically persistent, unexplicable backache. There can also be symptoms that suggest compression of the spinal cord or nerve root. The clinical presentation often includes medical emergencies, such as hypercalcemia, hyperviscosity and renal failure which are cardinal features in MM. Fatigue can be caused by anemia, which is typically normochromic and normocytic. Leukopenia and thrombocytopenia are less common presenting findings (Smith et al. 2005).

\subsection{Diagnosis}

The diagnosis of $\mathrm{MM}$ is usually confirmed by demonstration of a monoclonal protein (M-protein/paraprotein) in serum or urine and/or lytic lesions on X-ray together with an increased number of plasma cells in the bone marrow (Greipp 1992).

When MM is suspected, electrophoresis of serum and urine should be performed, followed by immunofixation to confirm and type any monoclonal protein present. Quantification of M-protein should be performed by densitometry of the monoclonal peak on electrophoresis. The serum free light chain(FLC) levels in combination with serum protein electrophoresis and immunofixation (IFE) yields high sensitivity and has major prognostic value in virtually all plasma cell disorders (Smith et al. 2005, Dispenzieri et al. 2010). The FLC assay is useful for monitoring many patients with oligosecretory and nonsecretory myeloma (Drayson et al. 2001, Dispenzieri et al. 2010). In theory, multiple myeloma can produce all classes of immunoglobulin, but IgG paraproteins are most common (53\% of MM), followed by $\lg \mathrm{A}(25 \%)$, light chain (Kor $\lambda$-light chain, $20 \%)$, IgD (1\%) and non-secretory MM (1\%). 
BM aspirate is sufficient to confirm diagnosis when it shows an infiltration of more than $10 \%$ plasma cells. However, BM trephine biopsy is often recommended as a baseline study against which treatment response is evaluated if aspiration yielded a poor specimen (Smith et al. 2005). Flow cytometry of BM aspiration allows the assessment of plasma cell phenotype, confirms clonality and permits determination of the proportion of plasma cells in cell cycle. For predictive purposes molecular genetic studies of plasma cells in bone marrow are to be recommended (see above). Cytogenetic changes can be utilised together with plasma cell immunophenotype to assess the presence of MRD if needed later.

Various imaging technologies have been used for diagnosis and response evaluation of MM patients. Conventional radiography still remains the gold standard of the staging procedure of newly diagnosed and relapsed MM patients (Dimopoulos et al. 2009a) and should be performed in all patients (Smith et al. 2005). Computed tomography and magnetic resonance imaging (MRI) scanning can be helpful in particular circumstances.

It is worth noting that for routine diagnostics, treatment and follow-up of MM patients, less investigations are mandatory than in clinical research. Thus, the correct diagnosis can be done without bone marrow biopsy, flow cytometry, cytogenetics or molecular genetic studies, imaging studies, e.g., computed tomography, magnetic resonance imaging, and positron emission tomography and light chain assays. However, in special clinical circumstances these tests may be helpful also outside clinical trials.

The differential diagnosis of MM includes MGUS, smoldering MM, primary amyloidosis, solitary plasmacytoma, low-grade lymphoma, chronic lymphocytic leukemia, B-cell non-Hodgkin lymphoma (including Waldenström macroglobulinemia) and metastatic carcinoma (Kyle and Rajkumar 2004, Smith et al. 2005). Because of the frequent use of serum protein electrophoresis and quite high prevalence of MGUS (3\% in those over 70 years old), it is important to distinguish MGUS from MM. The distinction between symptomatic and asymptomatic myeloma depends on the presence or absence of the CRAB signs (Table 1 and 2).

Table 1. Diagnostic criteria for MGUS, asymptomatic MM and symptomatic MM (according to the international Myeloma Working Group; Kyle et al. 2010). All criteria must be fulfilled.

\begin{tabular}{|c|c|c|c|}
\hline & MGUS & Asymptomatic MM & Symptomatic MM \\
\hline M-protein in serum(g/l) & $<30$ & $>30$ & $\begin{array}{l}\text { yes (and/or urine) } \\
\text { regardless of amount }\end{array}$ \\
\hline Bone marrow clonal plasma cell & $<10 \%$ & $>10$ & $\begin{array}{l}\text { yes or biopsy proven } \\
\text { plasmacytoma }\end{array}$ \\
\hline $\begin{array}{l}\text { Myeloma-related organ or tissue } \\
\text { impairment (including bone } \\
\text { lesions) or symptoms }\end{array}$ & no $+{ }^{a}$ & no & yes (see Table 2.) \\
\hline
\end{tabular}


Table 2. Myeloma-related organ or tissue impairment (CRAB; according to the international Myeloma Working Group; Kyle et al. 2010). At leats one criterion must be fulfilled at the diagnosis of MM.

(C) Increased calcium levels

(R) Renal insufficiency

(A) Anaemia

(B) Lytic lesions or osteoporosis with compression fractures (or other symptoms of MM, like symptomatic hypervicosity, amyloidosis, recurrent bacterial infections).

\subsubsection{Immunophenotype of multiple myeloma}

According to many studies flow cytometry yields better clinical sensitivity for analyzing the malignant plasma cells when compared to conventional morphology. Immunophenotyping of plasma cells is recommended for identification of aberrant phenotypes in clonal plasma cells at diagnosis; this information could be used later for monitoring of treatment response and for evaluating MRD. Clonality must be assessed by demonstration of cytoplasmic $\mathrm{k} / \lambda$ expression. According to the European Myeloma Network recommendation for the diagnosis of MM, MGUS and reactive conditions by flow cytometry antigens, such as CD19, CD56, CD117, CD20, CD28, CD27, CD81 and ,CD200, must be used (Rawstron et al. 2008; Table 3). In addition, antigens, such as CD45, CD56, CD117 and CD28, have been identified as prognostic markers for MM (Rawstron et al. 2008). Table 3. Most useful antigens for detection of aberrant plasma cells in MM (Rawstron et al. 2008).

Table 3.

\begin{tabular}{|c|c|c|c|c|}
\hline Antigen & $\begin{array}{l}\text { Normal expression } \\
\text { profile (\% on } \\
\text { normal plasma } \\
\text { cells) }\end{array}$ & $\begin{array}{l}\text { Abnormal } \\
\text { expression } \\
\text { profile }\end{array}$ & $\begin{array}{l}\% \text { of MM cases } \\
\text { with abnormal } \\
\text { expression }\end{array}$ & $\begin{array}{l}\text { Requirement for } \\
\text { diagnosis and } \\
\text { monitoring }\end{array}$ \\
\hline CD19 & Positive (>70\%) & Negative & $95 \%$ & Essential \\
\hline CD56 & Negative $(<15 \%)$ & $\begin{array}{l}\text { Strongly } \\
\text { positive }\end{array}$ & $75 \%$ & Essential \\
\hline CD117 & Negative $(0 \%)$ & Positive & $30 \%$ & Recommended \\
\hline CD20 & Negative $(0 \%)$ & Positive & $30 \%$ & Recommended \\
\hline CD28 & $\begin{array}{l}\text { Negative /weak } \\
(<15 \%)\end{array}$ & $\begin{array}{l}\text { Strongly } \\
\text { positive }\end{array}$ & $15-45 \%$ & Recommended \\
\hline CD27 & $\begin{array}{l}\text { Strongly positive } \\
(100 \%)\end{array}$ & $\begin{array}{l}\text { Weak or } \\
\text { negative }\end{array}$ & $40-50 \%$ & Recommended \\
\hline CD81 & Positive (100\%) & $\begin{array}{l}\text { Weak or } \\
\text { negative }\end{array}$ & Not published & Suggested \\
\hline CD200 & Weakly positive & $\begin{array}{l}\text { Strongly } \\
\text { positive }\end{array}$ & Not published & Suggested \\
\hline
\end{tabular}

In MM, the plasma cells express phenotypically monotypic cytoplasmic Ig and lack surface Ig. They express normally CD79a, CD38c, CD 138 and strongly CD38. In contrast to normal plasma cells they are usually CD19 and CD27 negative and CD56 and CD138 positive. In $60-70 \%$ of cases CD56 is aberrantly expressed. CD117, CD20, CD52, CD28 and CD10 can also be identified in MM plasma cells, in decreasing order of frequency (McKenna et al. 2008). Overproduction of interleukin-6, a plasma cell growth factor, tumor necrosis factor and interleukin- 1 is common. Deletions of p53, a tumor-suppressor gene, have also been reported in myeloma patients. (Bataille et al. 1995) 


\subsection{Bone disease}

Up to $90 \%$ of MM patients develop osteolytic lesions during the course of their disease (Terpos and Dimopolous 2005). These lesions occur predominantly in the axial skeleton, including skull, spine, rib cage, pelvis and the proximal parts of the arms and legs (Kyle et al. 2003b).

At diagnosis about $10 \%$ of patients have diffuse osteopenia or osteoporosis (Callander and Roodman 2001). Recently, the impact of bone resorption has been confirmed as an independent risk factor for overall survival (OS) for patients with active MM (Jakob et al. 2008). Progression of skeletal disease is often not affected by chemotherapy even in responding patients (Raje and Anderson 2001). Bone destruction represents a major cause of morbidity and mortality (Dimopoulos et al. 2009) and skeletal events decrease the patient's quality of life and increase treatment costs (Bruce et al. 1999). The mechanisms of bone destruction are related to increased osteoclastic bone resorption, which is accompanied by an exhausted osteoblast function and reduced bone formation which lead to the development of lytic lesions (Terpos and Dimopolous 2005, Giuliani et al. 2006).

The development of bone lesions is thought to be related to an increase in the expression by osteoblasts of the receptor activator of nuclear factor Kß ligand (RANKL) and a reduction in the level of its decoy receptor, osteoprotegerin (Roodman 2002). The increase in the ratio of RANKL to osteoprotegerin results in the activation of osteoclasts and bone resorption. Overexpression of RANKL is probably mediated in part by the release of macrophage inflammatory protein $1 \alpha$ by neoplastic plasma cells (Abe et al. 2002). Suppression of osteoblast precursor differentiation and induction of apoptosis in mature osteoblasts result in decreased bone formation. Overproduction of cytokines with osteoclast activation results from interaction between myeloma cells and bone marrow stromal cells. Increased production of molecules, such as dickkopf-1 and secreted frizzled-related protein 2 are responsible for osteoblast dysfunction (Silvestris et al. 2004).

It has been found in many studies that bisphosphonates prevent, reduce and delay MM-related skeletal complications (Terpos et al. 2000, Rosen et al. 2002). Intravenous pamidronate and zoledronic acid and oral clodronate have been shown to be useful bisphosphonates for the management of MM (Lahtinen et al. 1992, Berenson et al. 1998, Rosen et al. 2003). Recently, the Nordic Myeloma Study Groupit has been shown that skeletal events are prevented equally well with a of low dose $30 \mathrm{mg}$ of pamidronate as by $90 \mathrm{mg}$ (Gimsing et al. 2010). In the British Myeloma IX Study showed a survival benefit of 5.5 months with zoledronate treatment compared to clodronate (Morgan et al. 2010). According to the recommendations of an expert panel on behalf of the European Myeloma Network, bisphosphonates should be used for the treatment of MM patients with lytic bone disease or severe osteoporosis and given for 2 years or even longer if there is evidence of active bone disease (Terpos et al. 2009).

\subsection{Predictive factors and prognosis}

Patients with newly diagnosed MM need to be staged according to Durie and Salmon, which has been the classical prognostic model (Durie and Salmon. 1975; Table 4). The model is based on the analysis of 71 patients and has been the golden standard for the 
last quarter of century. The expected survival among Finnish MM patients is 68, 58 and 34 months for Durie-Salmon stages I, II and III, respectively (Oivanen et al. 1999).

Table 4. Durie-Salmon Staging System

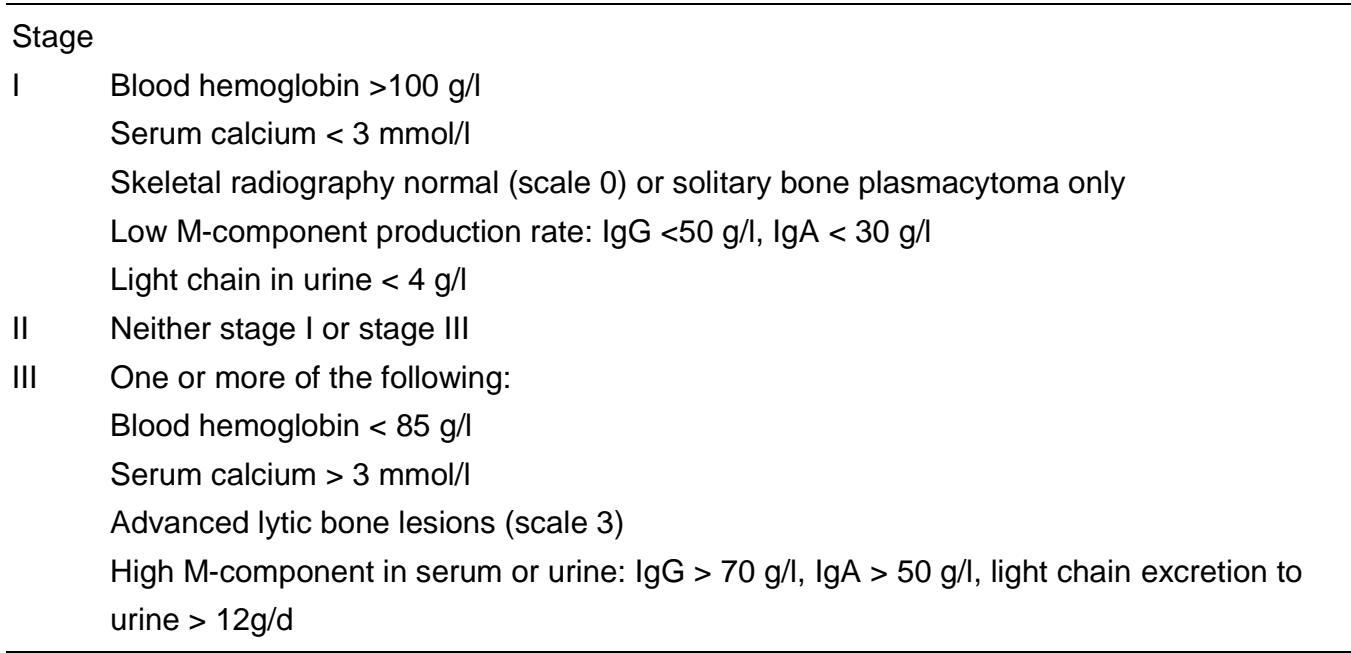

Durie-Salmon subclassification:

A: Normal renal function or slight azotemia (serum creatinine concentration $<180 \mu \mathrm{mol} / \mathrm{l}$ )

B: Abnormal renal function (serum creatinine concentration $\geq 180 \mu \mathrm{mol} / \mathrm{l}$ )

There have been many attempts to construct new prognostic models. In 2003, an International Staging System (ISS) was presented, based on the serum level of $B_{2^{-}}$ microglobulin and albumin. The ISS separated the patients into three prognostic groups (Greipp et al. 2003; Table 5). Patients with elevated $B_{2}$-microglobulin have a much shorter survival irrespective of treatment modality, age or geographic location.

There are, however, some drawbacks in the ISS. It cannot be used before the diagnosis of MM has been made and has thus no role in MGUS. The ISS does not identify adverse prognostic groups at sufficiently high risk to warrant a different therapeutic approach. Stage III is a composite group comprising patients with an elevated concentration of $B_{2^{-}}$ microglobulin, but this is due to tumor burden as well as to renal failure. A stronger riskstratification model is still needed (Rajkumar and Greipp, 1999).

Table 5. ISS staging system (Greipp et al. 2003).

\begin{tabular}{llll}
\hline Stage & $\begin{array}{l}\text { Serum } \boldsymbol{B}_{2^{-}} \\
\text {microglobulin }(\mathbf{m g} / \mathbf{l})\end{array}$ & $\begin{array}{l}\text { Serum albumin } \\
(\mathbf{m g} / \mathbf{l})\end{array}$ & $\begin{array}{l}\text { Median survival } \\
\text { (months) }\end{array}$ \\
\hline $\mathrm{I}$ & $<3.5$ & $>35$ & 62 \\
$\mathrm{II}$ & $<3.5$ or $3.5-5.5$ & $<35$ & 44 \\
$\mathrm{III}$ & $>5.5$ & & 29 \\
\hline
\end{tabular}

The natural history of MM is very variable with survival times ranging from a few weeks to over 20 years (Smith et al. 2005). The median survival once a diagnosis of MM has been made has until recently been approximately 3 to 4 years.

Cytogenetic abnormalities are strong prognostic factors. Genetic markers have also been examined to determine prognosis (Shaughnessy et al. 2007). There are several 
genetic categories defining subsets of the disease with dissimilar outcomes, pathologic features and treatment responses (Fonseca et al. 2003, Avet-Loiseau et al. 2007).

During the recent decade new markers of an adverse prognosis have been identified, e.g., complete deletion of chromosome 13 or its long arm, non-hyperdiploidy, $t(4 ; 14)$ or $\mathrm{t}(14 ; 16)$ translocation, deletion of $17 \mathrm{p} / \mathrm{TP} 53$ sequences and increased density of bone marrow microvessels. These novel markers complement established markers of adverse outcome, including an increase in PC labelling index, increased level of serum $B_{2}$-microglobulin, low level of serum albumin, plasmablastic features in bone marrow aspiration and circulating plasma cells (Bataille et al. 1992, Greipp et al. 1993, Rajkumar and Kyle 1999, Jacobson et al. 2003, Kyle and Rajkumar 2004). A new finding is that patients with a normalized FLC ratio during treatment have a better OS than patients with a pathological FLC ratio which is especially noteworthy in patients who are IFE negative (Kumar et al. 2008).

\subsection{Response criteria}

Over the years, several response criteria for MM have been developed. The most recent commonly used response criteria have been developed by The European Group for Blood and Bone Marrow Transplantation (EBMT; Blade et al. 1998) and the International Myeloma Working Group (IMWG; Durie at al. 2006; Table 6).

Table 6. Response criteria to treatment of MM according to the European Group for Blood and Bone Marrow Transplantation and the International Myeloma Working Group

\begin{tabular}{ll}
\hline Complete response (CR) & - negative IFE in serum and urine (follow-up min 6 weeks) \\
& $-<5 \%$ plasma cells in bone marrow - \\
& - disappearance of any soft-tissue plasmacytomas \\
& - no increase in lytic bone lesions \\
& - all above + normal serum FLC and ratio \\
Stringent CR & - otherwise similar to CR, but serum and urine M- \\
Near to CR (nCR) & component detectable by IFE \\
Very good partial response (VGPR) & $-\geq 90 \%$ reduction in serum M-component and urine M- \\
& component < 100mg/ $24 \mathrm{~h}$ \\
Partial response (PR) & $-\geq 50 \%$ reduction in serum M-component and \\
& $-\geq 90 \%$ reduction in urine M-component / 24 hours or $<$ \\
Stable disease (SD) & 200 mg (follow-up min 6 weeks) \\
Progressive disease (PD) & - not meeting criteria for CR, VGPR, PR or PD \\
& $-\geq 25 \%$ increase in serum M-component, at least $5 \mathrm{~g} / \mathrm{l}$, or \\
& in daily urine M-component \\
& - bone marrow plasma-cell percentage increase at least $10 \%$ \\
& - increase of lytic bone lesions or plasmacytomas \\
& - hypercalcemia \\
\hline
\end{tabular}

\subsection{Treatment of multiple myeloma}

If symptomatic MM is left untreated, the median OS is less than one year. However, there is no evidence that early treatment of asymptomatic MM is beneficial (Hjort et al. 1993, Grinani et al. 1996, Riccardi et al. 2000). The median time from diagnosis to symptomatic disease is 2 - 3 years. In the 1960 `s, alkylating agents and 
glucocorticosteroids offered the first effective treatment of the disease. For the three next decades melphalan and predisone (MP) remained the standard therapy for newly diagnosed, symptomatic MM. This palliation induced a median of 18 months of tumor regression and a median life expectancy of about 3 years (Bensinger 2008, Kumar et al. 2008). Many other drug combinations have been tried, including combination of alkylating agents, vincristine and antracyclines, without any consistent survival gain over MP (Myeloma Trialists`Collaborative Group 1998). With the introduction of HDM supported by ASCT a survival gain of a median of one year was attained (Attal et al. 1996, Child et al. 2003).

The treatment of MM has changed dramatically during the last ten years because of indroduction of the novel drugs, including thalidomide, bortezomib, and lenalidomide. Use of these drugs has resulted in impressive improvements over the historical response rates to conventional chemotherapy. CR rates up to $40 \%$ have been obtained with novel therapies alone or in combinations in first-line therapy of MM (Kumar et al. 2008, Durie 2010). Next few years will show if optimal use of novel therapies, instead of the current ASCT, will be the new standard of therapy for MM.

\subsubsection{Primary therapy}

\subsubsection{Drug therapy}

\subsection{First-line treatment of patients eligible and ineligible for transplantation}

Induction therapy is essential to improve the patient's performance status and to stabilize organ functions before stem cell collection and ASCT. Before the era of novel drugs, either dexamethasone alone or vincristine-doxorubicine (Adriamycin ${ }^{\circledR}$ )dexamethasone (VAD) was the most common induction therapy for patients eligible for high-dose treatment (HDT; Kumar et al. 2004). The CR rate before transplantation was only less than $5-10 \%$. An important observation was that drugs toxic to stem cells which may compromise stem cell mobilization, such as melphalan, must be avoided as first-line therapy.

Introduction of novel drugs to the first-line treatment menu has changed this scenario. The primary target of the novel drugs in this context is to increase the CR rate before ASCT and, indeed, the CR rate has increased to $40 \%$ - a figure similar to what is usually observed after ASCT following conventional induction regimens. The increased CR rate obtained before ASCT translates to increased post-transplant CR rates, as well. Importantly also, the novel drugs, when administered to patients with adverse risk factors, e.g., deletion 13 or translocation $t(4 ; 14)$ or $t(14 ; 16)$, may overcome the poor prognosis of these patients (Lonial 2010).

Patients aged over 65-70 years of age are usually considered transplant ineligible, mostly due to comorbidities and poor performance capacity. Until recently their standard treatment has been MP. In two recent randomized trials the superiority of MP plus thalidomide (MPT) over MP in elderly patients has been shown in terms of response rate, PFS and OS (Palumbo et al. 2006, Facon et al. 2007). Based on these results the European Medicines Agency (EMEA) approved use of MPT as frontline therapy for elderly patients. In a large randomized Nordic study between MPT and MP plus placebo a significant response rate by addition of thalidomide to standard MP in previously untreated patients over 65-years was shown, but however, the study did not 
confirm previous reports of improved progression free survival (PFS) and OS (Waage et al. 2010a). A meta-analysis of nearly 2000 patients in 6 randomized clinical trials compared the efficacy of MPT versus MP. The analysis demonstrated a significant beneficial effect on PFS and a trend favoring a significant difference in OS when thalidomide is added to MP for first line treatment of elderly patients with MM. The median OS was 39.7 months and the median PFS 20.4 months in the MPT arm; the corresponding values were 32.7 and 14.9 months in the MP arm (Waage et al. 2010b).

In the large randomized Vista study bortezomib combined with MP had also a significantly better response rate, PFS and OS than MP (San-Miguel et al. 2008). Similarly, lenalidomide with dexamethasone has also been used as frontline therapy for the elderly resulting in promising figures for short-term PFS and OS (Rajkumar and Palumbo 2007b).

\subsection{Novel drugs}

The increased understanding of the pathophysiology of MM has made it possible to develop molecularly targeted drugs for MM (Podar et al. 2009). Thalidomide was the first one of these drugs that was introduced to the care of patients with MM. The University of Arkansas pioneered the administration of thalidomide, a glutamic acid derivative with immunomodulatory and anti-angiogenetic action to patients with advanced, treatment-resistant MM (D’Amato et al. 1994). Several clinical randomized trials have followed and confirmed the efficiency of thalidomide in advanced MM: a PR rate about 25\% may be achieved with monotherapy (Singhal et al. 1999, Barlogie et al. 2001, Rajkumar et al. 2001, Weber et al. 2003).

After this success in the setting of advanced MM, thalidomide - with or without dexamethasone - was the first novel drug to be used as first-line therapy, and soon it replaced VAD as the standard of drug treatment of patients with newly diagnosed MM (Cavo et al. 2005, Lokhorst et al. 2008). However, thalidomide-based regimens result in a CR rate of only $\leq 10 \%$. The MRC IX study combined thalidomide, cyclophosphamide and dexamethasone as initial therapy, and a CR rate of $20 \%$ was achieved prior to ASCT. This figure reached to $50 \%$ after ASCT (Morgan and Davies 2005).

The first-in-class proteasome inhibitor bortezomib offers one of the most successful therapies against MM. It disrupts normal protein homeostasis by targeting the proteasome and affects many key functions in the pathophysiology of MM (Hideshima and Anderson 2002, Shah and Orlowski 2009, Lonial 2010). It has also beneficial effects on bone metabolism through osteoblast activation (Rajkumar et al. 2005).

Clinically, bortezomib can overcome the adverse outcome of molecularly defined highrisk MM. Phase II studies with bortezomib plus dexamethasone for patients with newly diagnosed $\mathrm{MM}$ have resulted in response rates as high as $88 \%$ and in apparent increases in CR and VGPR rates (22-31\%; Jagannath et al. 2005, Harousseau et al. 2006). These effects are comparable with those achieved with single ASCT, and may be translated to even higher CR and VGPR rates (50-60 \%) after ASCT. Combination treatments of bortezomib with doxorubicine or thalidomide as initial therapy have also resulted in response rates up to $90 \%$ and CR rates up to $40 \%$ (Oakervee et al. 2005, Wang et al. 2007).

The use of bortezomib as a single agent and with different combinations is regarded as the current standard of care and has gained wide acceptance also for the treatment of 
relapsed and refractory $\mathrm{MM}$, as well (Richardson and Anderson 2003) and newly diagnosed MM (Harousseau et al. 2006, Richardsson et al. 2008). The randomized trial of the Nordic Myeloma Study Group of nearly 400 patients was designed to explore the effect of a 21-week consolidation period of bortezomib, given 3-8 months after ASCT (Mellqvist et al. 2009). The results suggest that consolidation with bortezomib given as a single agent is feasible, improves treatment responses and reduces the relapse rate after ASCT. However, the role of bortezomib for maintenance therapy after ASCT or alloSCT (Kröger et al. 2006) is still investigational.

A third novel drug is lenalidomide, a thalidomide analogue with more potent antimyeloma activity in vitro and a different toxicity profile when compared to thalidomide. Two large phase III randomized trials involving subjects with relapsed MM have shown that lenalidomide plus dexamethasone is superior to dexamethasone alone in terms of response rate ( $60 \%$ vs $25 \%$ ) and CR rate (15\% vs $1-3 \%$; Weber et al. 2007 , Dimopolous et al. 2009). Studies on lenalidomide as first line treatment of MM have also been promising: high response rates have been reported, including rates of VGPR or better exceeding $40 \%$ (Dingli and Rajkumar 2010). A caveat needs to be noted: lenalidomide seems to increase the risk of mobilization failure in a great number of MM patients (Kumar et al. 2007) and this may limit its use for patients proceeding to ASCT.

The adverse event profiles differ somewhat between the novel drugs. While sensorymotor peripheral neuropathy is common and often the most disturbing adverse event related to thalidomide and bortezomib (Rajkumar et al. 2001, Richardson et al. 2002), the main adverse effent related to lenalidomide is myelotoxicity. The risk of thrombotic events increases with thalidomide and lenalidomide, especially when combined with other drugs, and prophylactic anticoagulation is needed (Osman et al. 2001, Weber at al. 2003).

\subsubsection{Autologous stem cell transplantation}

$\mathrm{MM}$ is one of the hematologic malignancies in which the impact of dose intensity has been demonstrated. In early 1980`s McElwain and Powles (1983) were the first to report that high doses of intravenous melphalan were able to overcome drug resistance and induce CR in previously treated MM patients. They reported that prior exposure or failure to respond to melphalan at a standard dose did not preclude subsequent induction of CR at higher doses. This conclusion has been confirmed by many other investigators (Björkstrand et al. 1995, Harousseau et al. 1995). The next step forward was the introduction of stem cell rescue in combination with HDM (Barlogie et al. 1987). HDT supported by autologous blood cell transplantation is currently a widely used treatment modality in various hematologic and oncologic malignancies. Nowadays HDM (200 $\mathrm{mg} / \mathrm{m}^{2}$ ) is the standard regimen preceeding ASCT. Since the pivotal study by the Intergroupe du Myelome (IFM) 90 where the superiority of HDT supported by ASCT over the standard MP treatment was demonstrated (Attal et al. 1996), MM has been the most common disease for which ASCT has been indicated both in Europe and USA (Attal et al. 2007). Though novel molecularly targeted therapies will probably change the treatment of MM in future, HDM supported by ASCT should still today be considered as the standard of care in patients under the age of 65 to 70 years.

Unfortunately, ASCT is not curative for the majority of patients in spite of its significant benefits. Several studies (icluding multiple phase II trials, case control series, a population-based study and a mature randomized study) have established the 
superiority of HDT over standard therapy (Cunningham et al. 1994, Attal et al. 1996, Barlogie et al. 1997, Palumbo et al. 1999, Lenhoff et al. 2000). The advantage of ASCT may be associated with an increase in CR and VGPR rates. The rates of CR after conventional therapy without ASCT have been 5-15\% (Attal et al. 1996, Hari et al. 2006) and with ASCT 20-45\% (Attal et al. 1996, Hari et al. 2006). Autografted MM patients will continue to relapse during several years after transplantation and most patients relapse or progress within two to three years.

The IFM was the first to demonstrate in a randomized IFM 90 trial the superiority of HDT supported by ASCT compared with conventional chemotherapy (Attal et al. 1996). Similar results in other randomised trials have been reported as well (Table 7; Child et al. 2003, Palumbo A et al. 2004, Blade et al. 2005, Fermand et al. 2005, Barlogie et al. 2006a).

Table 7. ASCT versus conventional chemotherapy (CC). Results of randomized studies (Attal et al. 2007).

\begin{tabular}{|c|c|c|c|c|c|c|c|c|}
\hline Study & $\mathbf{N}$ & Follow-up & $\begin{array}{l}\text { CR } \\
\text { CC }\end{array}$ & $\begin{array}{l}\% \\
\text { ASCT }\end{array}$ & $\begin{array}{l}\text { EF } \\
\text { CC }\end{array}$ & $\begin{array}{l}\text { onths } \\
\text { ASCT }\end{array}$ & $\begin{array}{l}\text { OS } \\
\text { CC }\end{array}$ & $\begin{array}{l}\text { nths } \\
\text { ASCT }\end{array}$ \\
\hline IFM90 $^{a}$ & 200 & $7 y$ & 5 & $22^{g}$ & 18 & $28^{9}$ & 44 & $57^{\text {h }}$ \\
\hline $\mathrm{MRC} 7^{\mathrm{b}}$ & 41 & $42 \mathrm{mo}$ & 8 & $44^{\mathrm{g}}$ & 19 & $31^{g}$ & 42 & $54^{g}$ \\
\hline MAG91 ${ }^{\mathrm{c}}$ & 190 & $56 \mathrm{mo}$ & 5 & $19^{g}$ & 19 & 24 & 50 & 55 \\
\hline PETH $^{\mathrm{d}}$ & 164 & $44 \mathrm{mo}$ & 11 & 30 & 33 & 42 & 61 & 66 \\
\hline USIG & 510 & $76 \mathrm{mo}$ & 15 & 17 & 14 & 17 & 38 & 38 \\
\hline IMMSG $^{\dagger}$ & 194 & $39 \mathrm{mo}$ & 6 & $25^{g}$ & 16 & $28^{g}$ & 42 & $58+{ }^{g}$ \\
\hline
\end{tabular}

IFM (Attal et al. 1996),

b Medical Research Council Adult Leukemia Working Party (Child et al. 2003),

c Group Myelome-Autogreffe (Fermand et al. 2005),

d Spanish cooperative group PETHEMA (Blade at al. 2005),

e US Intergroup trial (Barlogie et al. 2006),

f Italian Multiple Myeloma Study Group (Palumbo et al. 2004)

g $P<0.01$

h $P<0.05$

Compared with conventional chemotherapy, ASCT almost always prolongs PFS, but not OS (Koreth et al, 2007). In a meta-analysis involving 2411 patients with newly diagnosed $\mathrm{MM}$ included in randomized controlled trials comparing ASCT and chemotherapy, a PFS benefit for ASCT was demonstrated $(P=0.02)$ but no significant OS benefit $(P=0.4)$. Against this observation, it is curious that HDT supported by ASCT has achieved the standard treatment role for the management of MM without any clear-cut evidence of OS prolongation (Koreth et al. 2007). Patients with refractory disease may benefit from ASCT in the same way as those with primary responsive disease (Singhal et al. 2002).

\subsubsection{Tandem autologous transplantation}

In ASCT dose intensity seems to be critical. Accordingly, the question has been whether further consolidation can be achieved with additional cycles of ASCT. Tandem ASCT was introduced in the late 1980's (Harousseau et al. 1992, Barlogie et al. 1999) with the aim to increase the CR rate by repeated HDT. In tandem ASCT, the second ASCT is performed soon after the patient has been recovered from the first ASCT, usually within six months after the first ASCT. It is known that OS improves significantly if the patient is at least in a VGPR after conventional or ASCT therapy (Attal et al. 1996) 
and that if response to treatment improves from PR to CR, OS will significantly be prolonged from a median of 5.0 years to 8.3 years (Alexanian et al. 2001).

In the randomized IFM94 trial, single and tandem ASCT were compared (Attal et al. 2003). 399 previously untreated patients under the age of 60 years were randomly assigned to undergo either a single ASCT prepared by HDM $140 \mathrm{mg} / \mathrm{m}^{2}$ plus total body radiation therapy (TBI) or a double ASCT, the first prepared by HDM $140 \mathrm{mg} / \mathrm{m}^{2}$ and the second by HDM $140 \mathrm{mg} / \mathrm{m}^{2}$ plus TBI. The CR and VGPR rates were $42 \%$ in the single and $50 \%$ in the double ASCT group ( $P=0.10)$. Median survival was prolonged by 10 months with tandem transplant but the significant OS benefit emerged only after four years. The probability of EFS at 7 years was $10 \%$ versus $20 \%(P=0.03)$ and of OS $21 \%$ versus $42 \%$. The benefit in EFS but not in OS was confirmed by two other randomized studies (Cavo et al. 2007, Pineda-Roman et al. 2008).

Table 8. Single ASCT (S) versus tandem ASCT (T; Hari et al. 2006)

\begin{tabular}{lllllllll}
\hline Study & N & Follow-up & \multicolumn{2}{c}{ CR rate(\%) } & \multicolumn{2}{c}{ EFS (mo) } & \multicolumn{2}{c}{ OS (mo) } \\
& & & S & T & S & T & S & T \\
\hline IFM94 $^{\mathrm{a}}$ & 399 & 75 & 42 & 50 & 25 & $30^{\mathrm{g}}$ & 48 & $58^{\mathrm{g}}$ \\
MAG95 $^{\mathrm{b}}$ & 227 & 53 & 39 & 37 & 31 & 33 & 49 & $73^{\mathrm{g}}$ \\
Bologna $^{\mathrm{c}}$ & 220 & 55 & 35 & 48 & 22 & $35^{\dagger}$ & 59 & 73 \\
GMMG $^{\mathrm{d}}$ & 261 & $\mathrm{nr}$ & $\mathrm{nr}$ & & 23 & $29^{\mathrm{g}}$ & no difference \\
HOVON $^{\mathrm{e}}$ & 303 & 56 & 13 & $28^{\dagger}$ & 20 & $22^{\mathrm{g}}$ & 55 & 50 \\
\hline
\end{tabular}

a IFM (Attal et al. 2003),

b Group Myelome-Autogreffe (Fermand et al. 2003),

c Bologna 96 (Cavo et al. 2005),

d GMMG (Goldschmidt. 2005),

e Sonneveld et al. 2005)

f $P<0.01$

g $P<0.05$

$\mathrm{nr}=$ not reported,

The IFM 94 trial confirmed the feasibility of tandem ASCT, since $75 \%$ of the patients could undergo ASCT with a mortality rate of less than $5 \%$. The drawbacks of tandem ASCTs are an increase in hospitalization and overall health care costs, unrealistic expectations of cure and a lack of impact on early mortality (first four years after ASCT; Hari et all. 2006). The Hovon investigators reported that also the quality of life indices were significantly better in the first year after transplant in the single arm than in double arm group (Sonneveld et al. 2005).

In a number of randomized studies, single versus double ASCT have been prospectively compared (Table 8). A significant finding in the IFM 94 study was that the patients whose response was worse than VGPR after the first ASCT had a significant benefit from the second ASCT. Thus, the 7 -year OS was $11 \%$ in the single and $43 \%$ in the double ASCT group $(P<0.001)$. This finding contrasts with the finding that the patients who had at least VGPR after the first ASCT did not gain any significant survival benefit from the second ASCT (Attal et al. 2003). Similars results have been shown in the Bologna 96 study (Cavo et al. 2007). There are other studies with a shorter follow-up than in the IFM94 study in which no survival benefit for tandem vs single ASCT was reported (Bologna, HOVON, GMMG; Cavo et al. 2003, Sonneveld et al. 2005, Goldschmidt 2005). Thus, the role of tandem transplantation is not quite clear, but a feasible approach might be to consider tandem ASCT for those patients who are not in CR or nCR after the first ASCT. 


\subsubsection{Allogeneic transplantation}

For many hematological malignancies the only curative treatment option is alloSCT (Bensinger et al. 2007). After ASCT, all MM patients ultimately relapse and succumb in their disease. High treatment-related mortality (TRM; $30-50 \%$ ) during earlier years has restricted a wide use of alloSCT (Gahrton et al. 2001). The benefits of alloSCT are that the graft does not contain tumor cells and that an immunological graft versus MM (GvMM) effect exists (Tricot et al. 1996, Aleya et al. 2003).

In a retrospective case-control EBMT study on alloSCT versus ASCT, survival was significantly longer in patients who underwent ASCT, but the relapse rate was higher and the long-term outcome was better in alloSCT group (Björkstrand et al. 1996). AlloSCT induces the highest rate of remissions, including molecular remissions, resulting in longterm disease free survival (DFS) in over 30\% of patients (Voena et al. 2003, Bensinger 2004). Corradini et al (2003) have reported molecular remission only in $7 \%$ of patients after ASCT but in 50\% after alloSCT. Moreover, none of the 16 patients with a negative molecular status had relapsed at 5 years after alloSCT while all 13 patients with molecular positivity relapsed within 5 years after alloSCT. However, MM tends to relapse even several years after alloSCT, and less than $30 \%$ seem to be long-term survivors.

\subsubsection{Tandem autologous plus allogeneic transplantation}

Development of alloSCT with reduced-intensity conditioning (RIC-allo) has been changing the scene during the recent years as an attempt to decrease the transplantrelated toxicity while retaining the wanted GvMM effect. The adoptive immunotherapeutic effect of competent donor immune effector cells in eradicating the disease has been established. It is best shown by the use of donor lymphocyte infusions (DLI) to re-induce disease responses after relapse post-alloSCT (Child et al. 2003, Lokhorst et al. 2003). The GvMM effect of DLI has led to the use of DLI in the treatment of both persistent disease and relapse after alloSCT. The response rate to $\mathrm{DLI}$ is $45-60 \%$ and the CR rate $20-30 \%$, but the response lasts for more than 1 year only in $20 \%$ of the patients (Lokhorts et al. 2004).

The conditioning regimens consist usually either of fludarabine and melphalan with or without in vivo T-cell depletion (with antithymocyte globulin or alemtuzumab) or of lowdose TBI with fludarabine. The incidence of acute and chronic GVHD has been $30 \%$ and $50 \%$, respectively. RIC-allo is associated with a TRM less than $20 \%$ but at the cost of increased relapse rate (Einsele et al. 2003, Lee et al. 2003). The EBMT group has reported a retrospective study comparing 196 patients receiving myeloablative conditioning versus 320 patients receiving RIC-allo. The results are in Table 9, but the two populations were not entirely comparable because the patients in the RIC-allo group were older and had more resistant disease and were more heavily treated than the patients on myeloablative conditioning (Crawley et al. 2007).

Table 9. Myeloablative conditioning versus RIC-allogeneic transplantation, EBMT $1998-2002$ (Crawley et al. 2007).

\begin{tabular}{llllll}
\hline Procedure & No of patients & TRM\% & CR rate\% & PFS\% at 3y & OS\% at 3 y \\
\hline Myeloablative & 196 & 37 & 53 & 19 & 51 \\
RIC & 320 & 24 & 34 & 35 & 38 \\
P & 0.002 & $<0.001$ & $<0.001$ & $<0.001$ & \\
\hline
\end{tabular}


Considering the importance of a low tumor mass at the time of transplant for the success of RIC-allo, the use of ASCT and sometimes even tandem ASCT to reduce the tumor burden before RIC-allo has been investigated. In a study on ASCT plus RICallo, the TRM was $11 \%$ at day 100 and the CR rate $73 \%$ (Kröger et al. 2002). In three studies compairing tandem ASCT with single ASCT followed by RIC-allo, the TRM ranged from $10 \%$ to $16 \%$. The IFM study (Garban et al. 2006) and the PETHEMA study (Rosinol et al. 2009) found no benefit in terms of CR, EFS and OS but an Italian study (Bruno et al. 2007) did report an increased CR rate and a significant survival benefit for patients in the allo-RIC group.

The current consensus about alloSCT in MM is that this treatment modality can cure a minority of patients but at the cost of a high TRM. Thus, alloSCR with myeloablative conditioning is recommended within well-designed clinical trials. TRM is lower after $\mathrm{RIC}$-alloSCT but relapse risk is higher, and, accordingly, this treatment concept is also still investigational (Lokhorst et al. 2010).

\subsubsection{Other treatment phases}

\subsubsection{Advanced disease phases}

Relapsed, refractory, or progressive MM can repeatedly be controlled with MM drugs or their combinations but gradually the responses become weaker and shorter, and ultimately the disease becomes refractory and uncontrolled. Dexamethasone is the classical agent for treatment of advanced phases, usually given as high-dose pulses or combined with conventional chemoterapeutic drugs (Raab et al. 2009). The novel MM drugs presented above are the most effective ones in advanced disease phases, and they are usually combined with a corticosteroid, cytostatic agents, or with each other (Raab et al. 2009, Blade et al. 2010).

\subsubsection{Maintenance}

Maintenance chemotherapy has not been shown to offer any benefit for OS. Glucocorticosteroid maintenance prolongs the duration of response but an effect on survival has not been established (Berenson et al. 2002, Shustik et al. 2004). Cunningham et al (1998) showed in a randomized study that maintenance therapy with interferon a (IFN) prolonged EFS significantly, while OS was not affected. In a later study IFN had no impact on survival outcomes (Barlogie et al. 2006c). Novel agents will offer new possibilities for maintenance therapy, but the optimal maintenance treatment, if any, after an adequate response to conventional chemotherapy has not been established. There are some data that thalidomide may be beneficial as maintenance therapy after ASCT (Attal et al. 2006, Barlogie et al. 2006c, Spencer et al. 2007 ) but, on the other hand, early and prolonged use may hamper the treatment of later progression phase (Barlogie et al. 2006b).

Preliminary data of bortezomib and lenalidomide suggest that these drugs can overcome the poor prognosis associated with cytogenetic abnormalities (Jagannath et al. 2007) and are interesting alternatives for post-ASCT treatment. In the trial of Ladetto et al (2002) patients got 4 courses of consolidation treatment with bortezomib plus thalidomide plus dexamethasone after ASCT, and 6 out of 24 patients at least in VGPR after ASCT, achieved molecular remissions and none of them had a relapse with a median follow-up of 26 months. 


\subsubsection{Importance of complete response and molecular response}

The long-term outcome in myeloma has changed significantly during the last decade which has been linked to use of ASCT and new myeloma drugs, including thalidomide, bortezomib and lenalidomide (Brenner et al. 2008, Kumar et al. 2008, Raab et al. 2009). These treatment modalities are more effective than the traditional drugs in attaining CR or at least VGPR and a significant correlation between prolonged survival and good responses has been recorded both in the setting of upfront treatment and relapse treatment (van de Velde et al. 2007, Harousseau et al. 2009, Nooka et al. 2009). The significance of attaining CR has been known also when non-intense treatments without ASCT have been used, but the traditional treatments have yielded very low CR rates. With high-dose treatment and ASCT, CR or VGPR can be achieved in up to $50 \%$ of the patients and a similar efficacy can be reached with the new drugs in different combinations (San-Miguel et al. 2008). In addition to achieving CR or VGPR, the long duration of CR - more than 3 years from start of treatment - is a surrogate marker of prolonged survival (Barlogie et al. 2008). It is currently widely suggested that achieving $\mathrm{CR}$ is the therapeutic goal sought for in modern myeloma treatment (van de Velde et al. 2007, Harousseau et al. 2009, Ludwig et al. 2010).

In addition to the achievement of CR the depth of CR may also be important. Eradication of MRD has been shown to be crucial in many other hematological malignancies, e.g. the acute leukemias (Mortuza et al. 2002, Santamaria et al. 2007), chronic myeloid leukemia (Olavarria et al. 2001), chronic lymphocytic leukemia (Moreno et al. 2005, Itälä et al. 2008) and non-Hodgkin's lymphomas (Gribben et al. 1993). The two most important techniques to measure MRD are flow cytometry and polymerase chain reaction (PCR), the latter being more sensitive (Bacher et al. 2008). The sensitivity of detection of MRD by PCR has improved through progress in the techniques from qualitative PCR to semi-quantitative allele specific oligonucleotide (ASO)-PCR and finally to the most sensitive quantitative real-time ASO-PCR techniques with a maximal sensitivity of $10^{-5}$ to $10^{-6}$ (Blade et al. 1998, Verhagen et al. 2000, Van der Velden et al. 2003). Molecular remissions are associated with prolonged long-term survival, particularly after alloSCT (Corradini et al. 2003, Bakkus et al. 2004, Rasmussen et al. 2004). Because eradication of MRD may offer a chance for full cure, the suggested viewpoint is that future may set the goal for the treatment of MM not only at CR but at molecular CR.

There are, however, several studies in which achievement of CR has not translated into prolongation of patient survival (Dingli et al. 2007, Ludwig et al. 2010), although this should be the ultimate goal of treatment of MM (Bergsagel 2008, Durie 2010). There are patients for whom achievement of CR and its depth are a valid surrogate for prolonged survival, but this is not the case for all patients. Successful control of the proliferative, cytogenetically abnormal tumor compartment may be the critical end point in MM treatment, not only a cosmetic CR (Bergsagel 2008).

\subsection{Mobilization}

Composed of stromal cells, endothelial cells, osteoblasts and other matrix components, the bone marrow microenvironment anchors hematopoietic stem cells through a wide range of adhesive interactions (Nervi et al. 2006). Although a small number of hematopoietic stem cells circulate in the peripheral blood, mobilization is necessary to 
drive sufficient numbers of hematopoietic stem cells from the BM to the peripheral circulation, where they can be harvested by apheresis. Peripheral blood has appeared to be superior to BM as a source of hematopoietic stem cells for autologous transplantation, because collection is easier, morbidity is low and the time to engraftment is short (Beyer et al. 1995). Nearly $99 \%$ of adult stem cells are collected from peripheral blood.

After mobilization with chemotherapy and G-CSF, daily measurements of blood CD34+ cells are made when the blood leukocyte count recovers from its nadir and reaches the level of $1.0 \times 10^{9} /$. Leukapheresis will usually start when the blood CD34+ cell count exceeds $10-20 \times 10^{9} /$. The blood CD34+ cell concentration predicts accurately the stem cell yield after leukapheresis (Haas et al. 1994, Remes et al. 1997).

\subsubsection{Target stem cell dose}

The optimal target dose of infused CD34+ cells is around 4.0 to $5.0 \times 10^{6}$ per kilogram of patient weight for a single transplant (Fu and Liesveld 2000); the minimum is 1.5 to $2.0 \times 10^{6} \mathrm{CD} 34+$ cells $/ \mathrm{kg}$ (Gandhi et al. 1999). Higher stem cell doses are associated with faster platelet and neutrophil engraftment (Bensinger et al. 1995, Tricot et a. 1995, Sienna et al. 2000) and with a reduced need for transfused red blood cells and platelets (Sienna et al. 2000). In some studies, CD34+ cell doses over $3 \times 10^{6} / \mathrm{kg}$ have been associated with better outcomes, primarily due to faster hematological recovery and a lower incidence of infectious and bleeding complications (Bensinger et al. 1995, Desikan et al. 2001). However, most studies on the impact of the CD34+ cell dose have been retrospective and the CD34+ cell dose has not been associated with significantly differing outcomes. The suggestion of the International Myeloma Working Group for a minimum collection target is $4 \times 10^{6} \mathrm{CD} 34+$ cells / $\mathrm{kg}$ for one and $8-10 \mathrm{x}$ $10^{6}$ CD34+ cells / kg for two transplants (Giralt et al. 2009).

\subsubsection{Biology of stem cell mobilization}

The collected graft contains many cells besides CD34+ cells. It is well known that clonotypic MM cells regularly contaminate the blood stem cell harvest, as is the case for other hematological diseases with BM involvement. Thus, lymphoma cells were mobilied in $36 \%$ of patients tested, $78 \%$ of whom had follicular lymphoma (Gazitt et al. 2001). Mobilizing therapy has been modified in an attempt to purge the stem cell product in vivo and stem cell harvests have also been enriched by selecting CD34+ cells from the harvest product in vitro. These methods have, however, failed to demonstrate a benefial effect on treatment outcomes (Stewart et al. 2001, Remes et al. 2003).

Recently, more attention has been paid to the quality of the graft. The number of primitive stem cells (CD34+/ CD38-) in the graft seems to be important for long-term engraftment after SCT. It has also been shown that patients with MM, lymphomas or amyloidosis who achieve a high absolute lymphocyte count by day 15 after ASCT have significantly longer OS than patients with a low lymphocyte count. The lymphocyte count seems to recover early if there has been a high level of lymphocytes in the infused stem cell product (Atta 2009). It has also been demonstrated that the natural killer cells in the product translate to more rapid lymphocyte recovery and better outcomes (Porrata et al. 2004). Significantly higher lymphocyte counts in the graft have been reported when G-CSF alone has been used for mobilization compared to G-CSF 
combined with cyclophosphamide (CY; Hiwase et al. 2008). Mobilization with chemotherapy followed by G-CSF reduces significantly the precollection absolute lymphocyte count, which could impact on long-term outcomes, independently of the number of CD34+ cells infused (Atta et al. 2009).

\subsubsection{Stem cell collection}

The technique and the blood cell separator used to collect stem cells affect strongly to the yield of the cytapheresis. Large volume apheresis has been introduced to improve the harvest of stem cells; here the processed blood volume is more than 4-fold the patient's blood volume. This technique often produces thrombocytopenia as platelets are lost during the harvesting (Moog 2006). High levels of citrate are required to maintain anticoagulation and this often results in muscle or bone pain and cramping (Moog 2006). Despite these drawbacks, large volume cytapheresis facilitates ASCT in poor mobilizers, and a low pre-apheresis blood CD34+ count can sometimes be overcome with large volume collections (Majado et al. 2010).

\subsubsection{Mobilization strategy}

The yields of hematopoietic stem cells can vary greatly between the patients and the optimal strategy to mobilize hematopoietic stem cells from the bone marrow into the peripheral blood is still under investigation. Mobilization strategies consist of cytokines alone or combined with chemotherapeutic agents. The biological mechanisms through which cytokines induce peripheral blood stem cell mobilization are complex and not completely understood (Levesque et al. 2004). Mobilization with cytokines alone is well tolerated but collection of sufficient numbers of stem cells to support transplantation can be difficult, especially in patients who have previously been treated with many intensive chemotherapy regimens (Haas et al. 1994). A combination of cytostatic chemotherapy with G-CSF or granulocyte-macrophage colony-stimulating factor has been shown to be the most efficient regimen to mobilizate stem cells. When a myelosuppressive chemotherapeutic agent is added to a cytokine for mobilization, this improves the collection yield by a factor of 2.5 according to some reports (Bensinger et al. 1995), although no effect has also been reported (Alegre et al 1997). The use of chemotherapy agents in a mobilization regimen also increases the incidence of neutropenia and infections and requires increased personnel resources, hospitalizations, transfusions and antibiotics (Jantunen et al. 2003, Cupta et al. 2005). Individual responses to chemomobilization may result in irregular collection schedules that increase the need for resources (Bargetzi et al. 2003). Although chemomobilization is widely used, there is no standard strategy for stem cell mobilization.

\subsubsection{Chemotherapy}

High-dose CY (up to $7 \mathrm{~g} / \mathrm{m}^{2}$ ) plus G-CSF has, in some studies, been superior to CY 4 $\mathrm{g} / \mathrm{m}^{2}$ plus G-CSF with regard to the cytapheresis yield (To et al. 1990, Kotasek et al. 1992, Boiron et al. 1993, Goldschmidt et al. 1997). High-dose CY is, however, more toxic than low-dose CY and may cause deep and prolonged cytopenias (Goldschmidt et al. 1997, Marit et al. 1998). In a nationwide Finnish study, a low dose of CY (1.2 $\left.2.0 \mathrm{~g} / \mathrm{m}^{2}\right)$ plus G-CSF was found to be as effective as high-dose CY $\left(4 \mathrm{~g} / \mathrm{m}^{2}\right)$ plus GCSF in terms of adequate progenitor cell mobilization and was associated with less toxicity and less need for supportive care (Jantunen et al. 2003). Different 
chemotherapies can be used for mobilization, but drugs that are toxic to the stem cell should be avoided. Disease-specific chemotherapies are one appealing way to mobilize, for example in lymphoma.

\subsubsection{G-CSF}

G-CSF is the most frequently used cytokine for mobilization. Because filgrastim (FIL) has a half-life of $3-4$ hours, daily subcutaneous administration is required. FIL is usually administered subcutaneously at a dose of $5-10 \mu \mathrm{g} / \mathrm{kg}$ starting normally one day after the end of cytotoxic therapy and continuing each day until the end of leukapheresis. When G-CSF is used alone for mobilization, it is administered at doses ranging from $10 \mu \mathrm{g} / \mathrm{kg}$ to $32 \mu \mathrm{g} / \mathrm{kg}$ subcutaneously daily at least 4 days before the first apheresis and continued until the last apheresis session.

\subsubsection{Pegylated G-CSF}

Pegfilgrastim (PEGFIL) is a pegylated form of FIL, which has a prolonged terminal elimination half-life of 33 hours and self-regulating serum levels as a result of neutrophil-mediated clearance (Curran and Goa 2002, Zamboni 2003). A single dose of PEGFIL has been shown to be as effective as multiple doses of daily FIL in the management of chemotherapy-induced neutropenia (Green et al. 2003, Sienna et al. 2003). Twice daily FIL has been compared to PEGFIL $12 \mathrm{mg}$ and it was found that PEGFIL has substantial advantages over FIL, including a higher percentage of patients with successful collection, a yield of more than $1.5 \times 10^{6} \mathrm{CD} 34+\mathrm{kg}$, single injection (rather than 13 daily injections) and faster neurophil and platelet recovery (Tricot et al 2008). In the autograft setting there are a few single-arm studies where the feasibility and efficacy of single-dose PEGFIL for stem cell mobilization has been demonstrated. In patients with MM or lymphoma PEGFIL at doses $6-12 \mathrm{mg}$ s.c. has been successfully used for stem cell mobilization (Isidori et al. 2005, Steidl et al. 2005, Bruns et al. 2006). The $6 \mathrm{mg}$ dose has been shown to be as efficient as the $12 \mathrm{mg}$ dose (Isidori et al. 2005, Bruns et al. 2006) and mobilization efficacy and harvesting outcomes were comparable between the single-dose PEGFIL and daily FIL (Steidl et al. 2005, Bruns et al. 2006, Fruehauf et al. 2007).

\subsubsection{Plerixafor}

Stromal cell-derived factor-1 (SDF-1) is a chemokine constitutively expressed and produced in the stromal cells of the bone marrow. It induces the migration and homing of hematopoietic stem cells and progenitor cells through signalling via the G proteincoupled receptor C-X-C4 chemokine receptor type 4 (CXCR4; Peled et al. 1999). SDF1 plays a key role in regulating the movement of hematopoietic cells, including CD34+ hematopoietic progenitor cells (Aiuti et al. 1997). Plerixafor is a selective and reversible antagonist of CXCR4 and disrupts its interaction with SDF-1; this causes ng a rapid release of stem cells from bone marrow niches into the blood circulation (Gerlach et al. 2001, Hatse et al. 2002, Flomenberg et al. 2005 ).

In a study of MM and lymphoma patients who had failed at least one mobilization attempt, a combination of G-CSF and plerixafor led to successful mobilization in $70 \%$ of patients (Calandra et al. 2008). In 2009 the EMEA approved plerixafor for clinical use following mobilization with G-CSF for MM and lymphoma patients who are poor mobilizers. Allogeneic stem cells from sibling donors have been mobilized without G- 
CSF using plerixafor alone, and this has provided a more rapid and less toxic alternative to FIL (Devine et al. 2008). Plerixafor and FIL together mobilize more progenitor cells than FIL alone - the median increase is 8-fold compared to FIL alone (Fruehauf et al. 2009).

\subsubsection{Mobilization failure}

Definitions of the patients who are hard to mobilize varies, but usually mobilization is considered to have failed if the minimum collection target of $2 \times 10^{6} \mathrm{CD} 34+$ cells per $\mathrm{kg}$ of patient's body weight has not been reached or the peak blood CD34 ${ }^{+}$cell count after mobilization is too low to start apheresis, i.e., usually less than $10-15 \times 10^{6} / \mathrm{l}$. In a study of 840 patients with MM or non-Hodgkin's lymphoma, $10.8 \%$ of patients who were mobilized with a combination of chemotherapy and G-CSF were considered poor mobilizers (Wuchter et al. 2010). Unsuccessful stem cell mobilization leads to costly mobilization attempts or cancellation or, if possible, postponement of ASCT (Boeve et al. 2004).

There are a number of factors which impact successful mobilization. Some premobilization factors have been identified which affect negatively stem cell mobilization, such as age over 60 years (Bensinger et al. 1995), increasing amount of previous chemotherapy (Haas et al. 1994, Bensinger et al. 1995) and previous exposure to myelotoxic cytostatics (Goldschmidt et al. 1996, Drake et al. 1997, Marit et al. 1998). Melphalan is a well known stem cell toxin, but also carmustine, fludarabine and cladribine have been associated with unsuccessful mobilization. Use of lenalidomide seems to increase the risk of mobilization failure in a great number of MM patients as well (Kumar et al. 2007). The duration of treatment with stem cell toxins is also of importance (Goldschmidt et al. 1996, Clark and Brammer 1998).

Patients who are eligible for ASCT should first be treated with a regimen that is not toxic to hematopoietic stem cells. Conflicting results have been published on other premobilization factors that are associated with mobilization failure. Thus, a short time from the preceding chemotherapy before mobilization has (Kotasek et al. 1992, Haas et al. 1994) or has not (Koumakis et al. 1996, Drake et al. 1997,) had a negative impact and prior radiotherapy (Bensinger et al. 1995, Goldschmidt et al. 1996, Watts et al. 1997) has or has not (Drake et al. 1997) impaired stem cell mobilization. Also, involvement of the bone marrow by the malignant disease has (Bensinger et al. 1995) or has not a negative effect on mobilization (Kotasek et al. 1992, Koumakis et al. 1996). Regarding mobilization-related factors the mobilizing agents and their doses may also be critical. Sepsis (Johnson et al. 1995), febrile neutropenia (Kuittinen et al. 2004) and prolonged platelet recovery to $50 \times 10^{9} / \mathrm{l}$ (Marit et al. 1998) impair stem cell mobilization. An approach to hard-to-mobilize patients has been suggested in a recently published review (Table 10; Jantunen and Kvalheim 2010).

Table 10. Suggested approach with a hard-to mobilize patient (Jantunen and Kvalheim 2010)

\begin{tabular}{ll} 
Previously failed mobilization & $\begin{array}{l}\text { consider adding plerixafor to G-CSF or } \\
\text { chemo + G-CSF-mobilization } \\
\text { Consider adding plerixafor if blood CD34+ } \\
\text { First mobilization with G-CSF alone }\end{array}$ \\
$\begin{array}{l}\text { count is low }\left(<5 \times 10^{6} / I\right) \text { on day }+4 \\
\text { Consider adding plerixafor, if blood CD34+ } \\
\text { counts remain low }\left(<5 \times 10^{6} / I\right) \text { at the time of } \\
\text { marrow recovery (blood leukocyte count }>5- \\
10 \times 10^{9} / I\end{array}$ \\
\hline
\end{tabular}




\section{AIMS OF THE STUDY}

The purpose of this study was to evaluate the outcomes of patients of autologous stem cell transplantation for multiple myeloma in Turku University Central Hospital.

The specific aims were:

1. to identify patients at risk for mobilization failure

2. to compare short-acting and long-acting G-CSF as mobilizing agents in combination with chemotherapy

3. to compare the impact of single versus double autotransplantation on clinical outcomes

4. to clarify the effect of minimal residual disease assessed by quantitative allelespecific PCR on long-term outcome after stem cell transplantation 


\section{PATIENTS AND METHODS}

\subsection{Patients and data collection (I-IV)}

This study is a retrospective analysis of prospectively collected data of MM patients treated with ASCT between February 1992 and October 2006 in the Department of Hematology, Turku University Central Hospital, Turku, Finland. In the MRD study some patients treated with alloSCT were included. The hospital is a 1000-bed teaching facility with a hematology department of 24 beds. The hematology department serves as a tertiary referral centrer for the southwestern part of Finland and as a primary care facility for hematological diseases with a catchment area of about 200.000 patients. The department serves also as a transplant center for both autologous and allogeneic transplantations and serves other regions in addition to southwestern Finland.

In all studies the analyses were retrospective but based on prospectively collected data. Since the begin of SCT, data on SCT has been collected and analyzed in a SCT data base. One data set is provided to the EBMT registry, one to the International Bone Marrow Transplant Registry (IBMTR) and one is used for in-house purposes. A summary of the study subjects and design of the studies is shown in Table 11.

Table 11. Subjects and study designs (I-IV).

\begin{tabular}{|c|c|c|c|c|}
\hline Study & $\begin{array}{l}\text { Time } \\
\text { period }\end{array}$ & Patient population & $\begin{array}{l}\text { Number of } \\
\text { patients }\end{array}$ & Purpose of the study \\
\hline 1 & 1993-2003 & MM patients & 124 & $\begin{array}{l}\text { to evaluate factors } \\
\text { affecting mobilization of } \\
\text { stem cells }\end{array}$ \\
\hline II & $2005-2006$ & $\begin{array}{l}\text { patients with } \\
\text { lymphoproliferative } \\
\text { disease (including } \\
\text { MM patients) }\end{array}$ & $\begin{array}{l}114 \\
(54)\end{array}$ & $\begin{array}{l}\text { to compare short- and } \\
\text { long-acting G-CSF as } \\
\text { mobilizing agents }\end{array}$ \\
\hline III & $1992-2003$ & $\begin{array}{l}\text { auto transplanted } \\
\text { MM patients }\end{array}$ & 100 & $\begin{array}{l}\text { to compare single versus } \\
\text { double ASCT }\end{array}$ \\
\hline IV & 1997-2006 & $\begin{array}{l}\text { transplanted } \\
\text { MM patients }\end{array}$ & 155 & $\begin{array}{l}\text { to evaluate minimal } \\
\text { residual disease post- } \\
\text { transplant by qASO-PCR }\end{array}$ \\
\hline
\end{tabular}

\subsection{Stem cell mobilization: Predictive factors for mobilization failure and comparison between FIL and PEGFIL (I, II)}

\subsubsection{Patients}

In study I, 124 consecutive patients aiming at ASCT were evaluated at the time of stem cell mobilization and a comparison was made between those who failed to mobilize a sufficient amount of CD34+ cells (blood DC34+ cell count below $20 \times 10^{6} / /$; $n=20)$ and those who successfully mobilized stem cells $(n=104)$. The peak blood 
CD34+ cell count was used as a marker of mobilization success against which the various predictive factors were tested. Of these 124 patients, $90(73 \%)$ was mobilized during their first-line treatment phase and 34 (27\%) in later phases of the disease.

Study II was a case-matched analysis of the mobilization efficacy of long-acting PEGFIL in comparison with short-acting FIL. This study included 38 consecutive adult patients in 2005 - 2006 with a lymphoproliferative disease (MM, chronic lymphocytic leukemia (CLL) or lymphoma) who required stem cell mobilization prior to ASCT and who were successfully mobilized using PEGFIL. Each PEGFIL-patient was matched for age (+/- 5 years), disease and treatment with two historical patients who had been succesfully mobilized with daily FIL in 1996 - 2005 and who had been identified in a reverse order of time from a total number of 251 patients who were mobilized with FIL. Those who met the three selection criteria were chosen for case-matched controls. Patient characteristics and mobilization chemotherapy of study I and II are seen in Table 12. Written informed consent was obtained from each patient. The study was conducted according to good clinical practice standards. The analysis was included in the quality management program of the stem cell transplantation program, accredited by Joint Accreditation Committee - ISCT (International Society for Cellular Therapy) and EBMT in 2006 and by the Finnish authorities (EU directive 2004/23/EY on the use of human tissues and cells). 


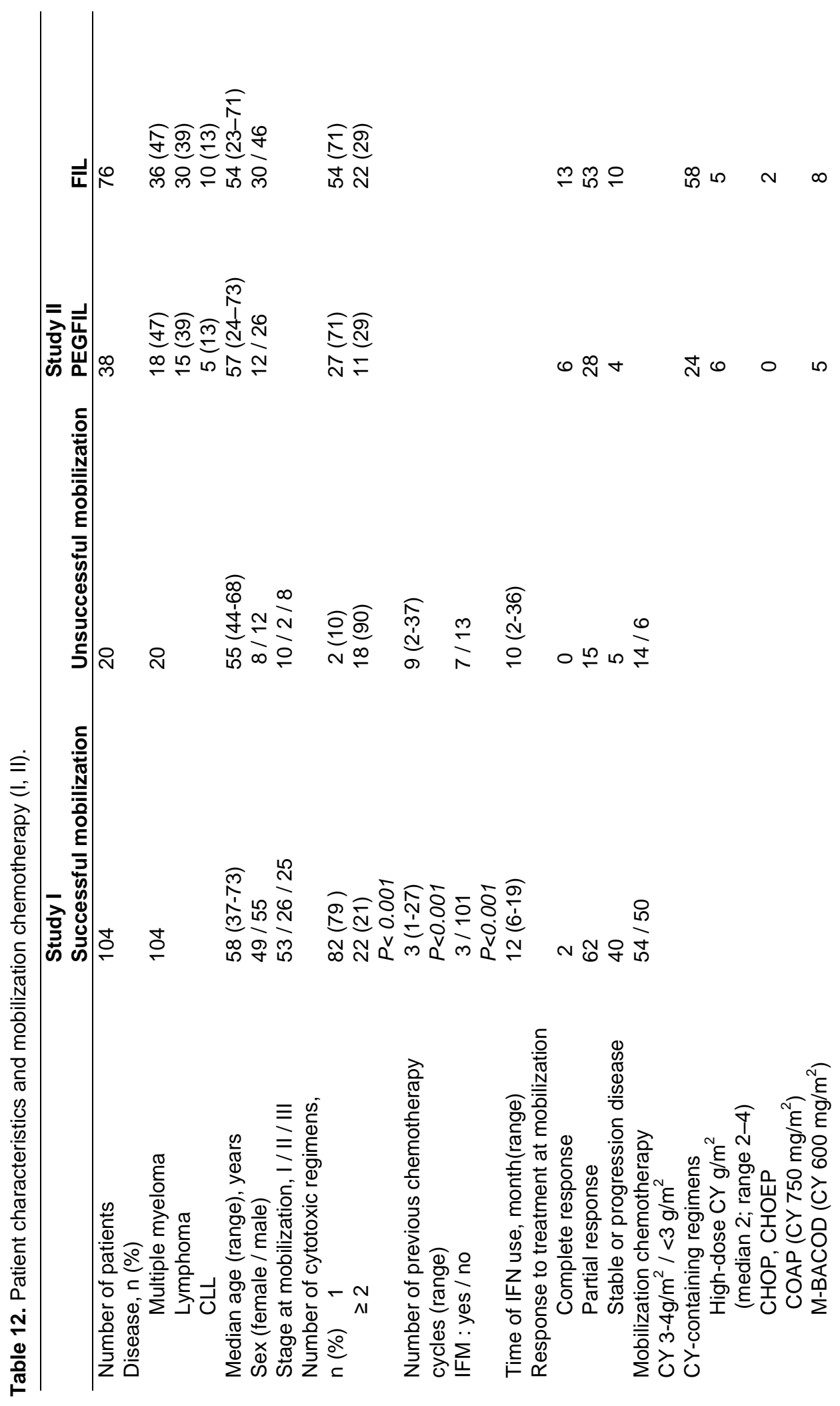




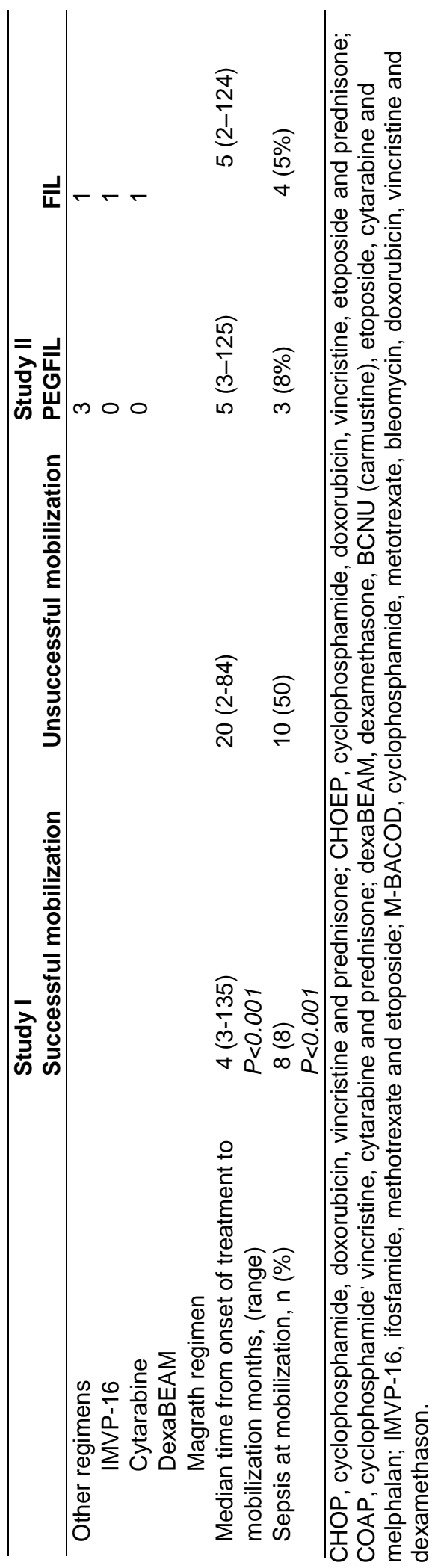




\subsubsection{Mobilization therapy}

Most patients ( $n=103$ ) in study I were mobilized with chemotherapy plus G-CSF and only one patient received growth factor alone. The first patients were mobilized in the 1990 's and at that time we used CY $3-4 \mathrm{~g} / \mathrm{m} \quad(n=68)$ to $1.2-2.5 \mathrm{~g} / \mathrm{m} \quad(n=56)$ for mobilization. G-CSF was administered on the day following the chemotherapy at a dose of $5-10 \mu \mathrm{g} / \mathrm{kg} / \mathrm{d}$ s.c. and was continued until the last day of leukapheresis or was stopped earlier if the mobilization of CD34+ cells into the blood appeared to be insufficient.

All patients in study II received mobilizing cytostatic chemotherapy according to standard practice. The most frequently used mobilization chemotherapy was high-dose $\mathrm{CY}$, at a dose of $1.5-2 \mathrm{~g} / \mathrm{m}^{2}$ for patients with MM and $2-4 \mathrm{~g} / \mathrm{m}^{2}$ for lymphomas if used as a single agent. PEGFIL was given on day 2 to the majority of patients, one day after the end of one-day cytotoxic therapy. If the chemotherapy course was longer, PEGFIL was administered one day after the last dose. Most patients $(n=29,76 \%)$ were administered PEGFIL at a dose of $12 \mathrm{mg}$; however, the first patient included in the study (with lymphoma) was treated with PEGFIL at a dose of $18 \mathrm{mg}$, while the last 8 patients ( 5 with MM, two with CLL and 1 with lymphoma) received a $6 \mathrm{mg}$ dose. FIL was administered at a dose of $5 \mu \mathrm{g} / \mathrm{kg}$ from day 2 , or one day after the end of cytotoxic therapy and was continued daily until the end of the leukapheresis.

\subsubsection{Stem cell collection}

Following mobilization with chemotherapy plus G-CSF, daily measurements of blood CD34+ cells were initiated on days 9-10 when the blood leukocyte count had recovered from its nadir to a level of at least $1.0 \times 10^{9} /$. In study I apheresis was initiated when the blood CD34+ count reached $\geq 20 \times 10^{6}$ cells/l; the aphereses of the first patients were started when the blood CD34+ cell count exceeded $10 \times 10 / \mathrm{l}$. In study II, apheresis was started when the blood CD34+ count reached $\geq 15 \times 10^{6} / \mathrm{l}$, with three exceptions in the FIL group where apheresis was started when blood CD34+ count was between 10 and $15 \times 10^{6} /$.

The target yield for a single transplantation was $4 \times 10^{6} \mathrm{CD} 34+$ cells $/ \mathrm{kg}$ of patient's body weight but a minimum of $1.5 \times 10^{6} \mathrm{CD} 34+$ cells $/ \mathrm{kg}$ was accepted for transplantation. For patients with MM aged less than 60 years, the aim was to collect sufficient stem cells for a double transplantation $\left(\geq 6 \times 10^{6} \mathrm{CD} 34+\right.$ cells $/ \mathrm{kg}$ ).

Before February 2000 the aphereses were performed using a Fenwal CS-3000 Plus device (Baxter Healthcare Corp., Deerfield, IL, USA; ( $n=86$ in study I and $n=13$ in study II). After this date, the aphereses were performed using the COM.TEC Blood Cell Separator (Fresenius Hemo Care, Bad Homburg, Germany) with a reduced volume program. Whole blood flow rates were $50-70 \mathrm{ml} / \mathrm{min}$. Until 2004 a total of approximately $10 \mathrm{I}$ of blood was processed for each collection. Since the beginning of 2004 the apheresis collection volume was increased to a mean of 12 I (range 6.6-17.4 I). The final product containing $10 \%$ dimethyl sulfoxide (DMSO) was frozen using a computer-controlled freezer device (Kryo 10, Planer, Sunbury-on-Thames, UK) and stored at $-196{ }^{\circ} \mathrm{C}$ in liquid nitrogen until used. 


\subsubsection{Stem cell transplantation}

Patients achieving the acceptable yield of CD34+ cells underwent high-dose chemotherapy followed by ASCT. High-dose chemotherapy was selected according to patients' disease, and mainly melphalan $200 \mathrm{mg} / \mathrm{m}^{2}$ was used for myeloma and BEAM (BCNU, etoposide, ara-C, melphalan) for lymphoma. After stem cell infusion G-CSF was administered until the neutrophil count was $\geq 1.0 \times 10^{9} / \mathrm{l}$.

\subsubsection{Study endpoints}

Successful mobilization was defined as a sufficient mobilization of CD34+ cells into the blood so that a sufficient number of CD34+ cells could be harvested. Accordingly, the primary study endpoint was the blood CD34+ concentration at onset of cytapheresis (Study I and II) or also peak blood CD34+ cell count after mobilization (Study I).

\subsubsection{Laboratory methods}

Blood and apheresis CD34+ cells were counted by flow cytometry. Until mid 1999, a two-platform method was used (Remes et al. 1997) but this procedure was later modified according to the Nordic recommendations (Johnsen 1995). Since then, a single-platform assay in TrueCount ${ }^{\mathrm{TM}}$ tubes using Procount ${ }^{\mathrm{TM}}$ reagents and software have been used (Becton-Dickinson, San Jose, CA, USA), using a FacsScan flow cytometer (Becton-Dickinson) until late 1999 and a FacsCalibur (Becton-Dickinson) flow cytometer thereafter.

\subsection{Single versus double ASCT (III)}

\subsubsection{Patients}

A total of 100 consecutive patients with newly diagnosed MM treated with HDT and ASCT in 1992 - 2003 were included. 73 patients received a single ASCT and, since the beginning of the double transplant program in 1996, 27 patients under the age of 61 years have received a double ASCT. Four patients older than 61 years were treated according to the double ASCT protocol and are included in the analysis. There were 40 patients who would have been candidates (age <61 years) for double autografting but who received only a single ASCT. The reasons for omitting the second transplant were: mobilization failure ( 3 patients), the patient's own wish to delay the transplantation until relapse ( 9 patients), and 28 patients were transplanted before the double autotransplantation program started. This analysis is consequently not an intention-totreat analysis, but rather an analysis of what actually happened, i.e. an observational study. The patient characteristics at diagnosis and the treatment details are given in Table 1 (III). The patients gave informed consent and the prospective double autografting protocol was approved by the Institutional Ethics Committee.

\subsubsection{High-dose therapy and ASCT}

After initial debulking therapy with three to four cycles of VAD, stem cell mobilization with high-dose CY and FIL was performed. 37 (37\%) patients received a CD34+ cell selected graft (21 patients in the single and 16 in the double ASCT group). Because we had previously shown no difference in the outcomes between CD34+ cell selected 
and unselected autografting (Remes at al. 2003), all ASCTs have been put together for this analysis. All patients underwent autografting with a graft collected from peripheral blood. Of the 100 patients in study III, 64 are included in study I.

In the single ASCT group, HDT consisted of $140 \mathrm{mg} / \mathrm{m}^{2}$ melphalan + TBI 12 GY in 5 fractions for the first 20 patients (27\%) and for one patient in the double ASCT group. HDM alone at a dose of $200 \mathrm{mg} / \mathrm{m}^{2}$ was used for 53 patients $(73 \%)$ in the single ASCT group and for 26 patients (96\%) as the first transplant and for all patients as the second transplant in the double ASCT group. Prophylactic G-CSF was started on day +4 after HDM at a daily dose of 300 to $480 \mu \mathrm{g}$ s.c. and continued until the neutrophil count exceeded $1.0 \times 10^{9} / \mathrm{l}$.

In the double ASCT group, the median time from the first HDT to the second was 5 months (range 2.5 - 12 months). After HDT and autografting, IFN was started for $57 \%$ of the patients (42 patients) in the single ASCT group and for $41 \%$ (11 patients) in the double ASCT group. The median duration of IFN treatment was 11 (1-101) months in the single ASCT group and $16(2-45)$ months in the double ASCT group.

\subsubsection{Study endpoints}

Response rate, PFS and OS were assessed among the patients receiving a single or a double ASCT. The median follow-up from the time of the first transplant of the living patients was $51(4-138)$ months in the single ASCT group and $46(10-78)$ months in the double ASCT group.

\subsubsection{Response criteria}

The responses to the treatment were determined according to the EBMT response criteria (Blade et al. 1998).

\subsection{MRD, assessed by qASO-PCR (IV)}

\subsubsection{Patients}

From October 1997 to June 2006 a total of 134 autologous (double 35) and 21 allogeneic SCT were performed at our institution to treat patients with MM. Of the105 patients who attained CR or nCR according to the EBMT response criteria (Blade et al. 1998), 43 were randomly chosen for molecular analysis. A patient-specific probe could be made for 37 patients (86\%) and used for MRD status assessment with quantitative ASO-PCR (qASO-PCR) after SCT. The 37 patients were divided into two groups based on their lowest qASO-PCR status 3-6 months after transplantation, i.e. MRD $\leq$ $0.01 \%$ (the MRD low/negative group) or MRD > 0.01\% (MRD high group). This cut-off value was chosen because it represented the median of the MRD measurements and has also been used by others (Bakkus et al. 2004). In addition to qASO-PCR, serum/urine IFE was performed $3-6$ months after transplantation at the same time as the respective qASO-PCR measurement. The cut-off date of this analysis was December 31, 2007. The characteristics of the patients are presented in Table 1 (IV). 


\subsubsection{Stem cell transplantation}

Of the patients with a PCR probe, 30 received high-dose melphalan $\left(200 \mathrm{mg} / \mathrm{m}^{2}\right)$ and single $(\mathrm{N}=20)$ or double $(\mathrm{N}=10)$ ASCT after initial debulking therapy. Seven patients underwent allogeneic SCT, three with myeloablative and four with RIC. In the allogeneic setting, the myeloablative conditioning regimen consisted of melphalan 110 $\mathrm{mg} / \mathrm{m}^{2}$ and total body irradiation (TBI; $12 \mathrm{~Gy}$ ); fludarabine $30 \mathrm{mg} / \mathrm{m}^{2}$ for 3 days and TBI 2 Gy were used in RIC. Treatment responses before and after transplantation are seen in Table 13. All the data of transplanted MM patients were prospectively collected into our transplant database for subsequent analyses to which the patients had given informed written consent. The study was conducted according to GCP standards. The analysis was included in the quality management program of the stem cell transplantation program and accredited by JACIE/EBMT in 2006 and by the Finnish authorities (EU directive 2004/23/EY on the use of human tissues and cells).

Table 13. Stem cell transplantations during the study period October 1997 to June 2006 . Treatment responses (\% of patients) before and after transplantation

\begin{tabular}{lcccccccc}
\hline Response & \multicolumn{2}{c}{$\begin{array}{c}\text { Single ASCT } \\
\mathbf{n}=\mathbf{9 9}\end{array}$} & \multicolumn{2}{c}{$\begin{array}{c}\text { Double ASCT } \\
\mathbf{n}=\mathbf{3 5}\end{array}$} & \multicolumn{2}{c}{$\begin{array}{c}\text { Auto-alloSCT } \\
\mathbf{n}=\mathbf{6}\end{array}$} & \multicolumn{2}{c}{$\begin{array}{c}\text { AlloSCT } \\
\mathbf{n = 1 5}\end{array}$} \\
& Before & After & Before & After & Before & After & Before & After $^{\mathbf{a}}$ \\
\hline $\mathrm{CR}$ & 2 & 43 & 1 & 15 & 0 & 3 & 2 & 7 \\
$\mathrm{nCR}$ & 9 & 23 & 6 & 11 & 2 & 1 & 0 & 1 \\
$\mathrm{PR}$ & 47 & 27 & 20 & 8 & 2 & 1 & 10 & 3 \\
$<\mathrm{PR}$ & 41 & 6 & 8 & 1 & 2 & 1 & 3 & 2 \\
\hline
\end{tabular}

Abbreviations: $\mathrm{CR}=$ complete remission, $\mathrm{nCR}=$ near to $\mathrm{CR}, \mathrm{PR}=$ partial response, $<\mathrm{PR}=$ inferior to $\mathrm{CR}$

${ }^{\mathrm{a}}$ two deaths

\subsubsection{Study endpoints}

The primary study endpoints were, firstly, the MRD status assessed by qASO-PCR after SCT and, secondly, PFS and OS in the MRD low/ negative and MRD positive groups.

\subsubsection{Laboratory methods}

\subsubsection{1 qASO-PCR}

Individual ASO- primers were designed for each patient to match the hypervariable CDR3 region for the sequenced IgH-gene using the Primer Express software (Applied Biosystems, Foster City, CA, USA). For a few of the patients $(n=12)$ a SybrGreen based detection and two ASO-primers were used with the forward primer in the CDR2 or FR3 region and the reverse primer in the CDR3 region. In SybrGreen based assays the amplification was considered positive and quantified only if the dissociation curve was consistent with a specific PCR product with an expected melting temperature. For most of the patients $(n=25)$ only one ASO forward primer was used and the consensus TaqMan and reverse oligonucleotides were selected according to the $J_{H}$ gene employed in the rearrangement. The sequences of the consensus primers and TaqMan probes have been published (Verhagen et al. 2000).

qASO-PCR was carried out in a SDS-5700 sequence detector (Applied Biosystems). $500 \mathrm{ng}$ of DNA was amplied in $25 \mu$ triplicate reactions using $300 \mathrm{nM}$ of the consensus 
$J_{H}$ germline and the individual ASO primer, $200 \mathrm{nM}$ of TaqMan probe annealing to a downstream family specific $J_{H}$ region and TaqMan Universal Mastermix (ABI) with UNG (Applied Biosystems). Reaction conditions were 2 min $50^{\circ} \mathrm{C}$ followed by $10 \mathrm{~min} 95^{\circ} \mathrm{C}$ followed by 50 cycles of $15 \mathrm{~s} 95^{\circ} \mathrm{C}$ and $1 \mathrm{~min} 60^{\circ} \mathrm{C}$. All PCR reactions were run in triplicate. For almost all of the patients the primers could be designed so that the above mentioned standard combined annealing-elongation temperature $\left(60^{\circ} \mathrm{C}\right)$ could be used. For a few patients slight modifications were made to this temperature to increase specificity.

Fluorescence data were analyzed using the GeneAmp ® 5700 SDS Software version 1.3 and its relative quantification procedure. For this purpose, the standard curve was constructed from each patient's pre-treatment sample. A logarithmic ten-fold dilution series down to $0.001 \%$ dilution was prepared from it by diluting DNA isolated from bone marrow mononuclear cells of the pretreatment sample into the peripheral blood mononuclear cell DNA pool from 12 healthy donors. The percentage of tumor cells in the pretreatment sample was evaluated by microscopic examination of the bone marrow aspirate drawn at the same time as the sample for DNA isolation. This proportion of tumor cells was used as a correction factor for the relative quantification. The European Study Group guidelines (Van der Velden et al. 2007) were used to define an acceptable slope $(-3.0$ - -3.9) and correlation coefficient $(>0.98)$ for the standard curves. To adjust the results to the quantity and quality of DNA, we used the albumin gene as a control gene in all quantitative PCR-analyses. The sequences of the forward and reverse primers for the albumin gene are TGAAACATACGTTCCCAAAGAGTTT and TTGATTTGTCTCTCCTTCTCAGAAAG, respectively and the sequence of the FAM-labelled and TAMRA-quenched TagMan probe is TGCTGAAACATTCACCTTCCATGCAGA. The guidelines of the European Study Group were used to define the specificity criteria and sensitivities for each of the ASO-primer sets and respective patients. The proportion of tumor cells in the pretreatment sample was included as a correction factor in these calculations. The achieved sensitivity was usually between $1: 10^{4}-1: 10^{5}$.

\subsubsection{IFE}

Semiautomated agarose IFE was performed with Hydrasys LC and Hydragel 4 IF immunofixation gels (Sebia, Evry, France) as instructed by the manufacturer. After automated electrophoretic separation, monospecific antisera (anti-lgG, anti-lgA, antiIgM, anti-kappa or anti-lambda and, if necessary, also anti-lgD or anti-lgE) were applied to the electrophoresis lanes for immunoprecipitation. The final step consisted of staining, destaining and drying in the staining compartment of the instrument. Monoclonal bands were detected by visual inspection of the stained gels. The system processes simultaneously four IFE samples. Serum samples were diluted 1:12 for the IgG lane, 1:6 for the kappa and lambda lanes and 1:3 for the other lanes. If necessary, the dilution was adapted according to the concentration of the paraprotein. Urinary paraprotein detection and characteriszation was performed with non-concentrated urine and Hydragel 4 Bence Jones gels (Sebia). All antibodies used for IFE were from Sebia. 


\subsection{Statistical analyses}

\subsubsection{Studies I, II}

Clinical and laboratory data were analyzed using the statistical program package SPSS for Windows 11.5. In neither of the two studies I and II were there any statistically significant differences in the variables between the groups in terms of classification of the disease stage at diagnosis and response to treatment at mobilization. Because most of the variables were non-normally distributed, medians and ranges are used to describe the distribution of continuous data. Continuous and ordinal data were tested using the Mann-Whitney U-test and nominal data using the $\mathrm{X}^{2}$-test or Fisher's exact test, where appropriate. All tests were two sided at the $5 \%$ significance level. Multiple logistic regression analysis was used in study I to examine which of the covariates had independent predictive power of mobilization success. The following categorical explanatory variables were tested: previous use of IFN, occurrence of post-mobilization sepsis, CY dose used for mobilization, number of previous chemotherapy cycles (more than five or less than six) and number of previous chemotherapy regimens (more than one or one). The platelet and leukocyte count nadirs were used as continuous explanatory variables. These explanatory variables were chosen using a stepwise backward technique, with the probability for entry to the model being 0.05 and removal 0.10 . Because of colinearity, the remaining covariates with statistically significant differences in univariate analyses were excluded from the model testing. The assumptions of multiple logistic regression analysis were checked and met.

\subsubsection{Study III}

The statistical program package SPSS for Windows 11.0 was used to analyze the data. The duration of overall OS was calculated for all patients from the first HDM to death. The duration of PFS was calculated for patients who had at least a minimal response from the date of the first HDM to date of progression. Kaplan-Meier curves for OS and PFS were plotted and compared with the use of the log-rank test.

\subsubsection{Study IV}

The clinical and laboratory data of the patients were analyzed using the statistical program package SPSS 15.0 for Windows. For estimating the survival rate for the PCR negative and PCR positive groups and for the IFE negative and positive groups, the Kaplan-Meier method was used. The requirements of survival analysis were met. The log rank test was used to compare the survival curves. OS and PFS were calculated from the date of the first transplant to death or progression, respectively. Relapse or progression were defined according to the EBMT criteria. 


\section{RESULTS}

\subsection{Prediction of mobilization failure (I)}

The details of mobilization therapy of patients with successful and unsuccessful mobilization are shown in Table 2 (I). There were no statistically significant differences of the classifying variables between the groups (disease stage at diagnosis, response to treatment at mobilization). The treatment responses at mobilization of all patients were: $10 \%$ CR or VGPR in both mobilization groups, $54 \%$ PR $(52 \%$ in successful and $65 \%$ in unsuccessful group) and $36 \%$ stable or progressive disease $(38 \%$ and $25 \%$, respectively).

The median peak blood CD34+ cell count (and ranges) in the group of unsuccessful mobilizations was $3.8(0.0-20.0) \times 10^{6} / /$ and in the successful group $110(13.0-$ $705.0) \times 10 / /$; the CD34+ count was less than $20 \times 10^{6} / /$ in two patients with successful harvesting. After successful mobilization, a median of $9.8(2.1-36.9) \times 10$ $\mathrm{CD} 34+$ cells $/ \mathrm{kg}$ were collected with a median of $2(1-5)$ aphereses, which were begun at a median of $9(7-19)$ days after mobilization chemotherapy. Of the 20 patients with mobilization failure, 8 underwent unsuccessful attempts to harvest with 2 to 5 additional cytaphereses.

\subsubsection{Predictive factors for successful CD34+ cell mobilization}

The patients characteristics and clinical data of patients who underwent successful and unsuccessful mobilization are shown in Table 1 (I) and the details of the mobilization therapy in Table 2 (I). The predictive premobilization factors that significantly differ between the successful and unsuccessful groups by univariate analyzes are previous use of IFN therapy $(P<0.001)$ and the occurrence of postmobilization sepsis $(P<0.001)$, which all had a negative impact on CD34+ cell mobilization. The distribution of MM types was different in the groups because of a higher proportion of light-chain disease in the group with successful mobilization $(P<0.05)$. Otherwise there were no statistically significant differences regarding the classifying variables between the groups in terms of disease stage at diagnosis and response to treatment at mobilization. By univariate analyzes, the difference of MM type between the successful and unsuccessful groups was not significant. The factors that had the statistically most significant negative predictive value for CD34+ cell mobilization were the number of chemotherapy cycles $(P<0.001)$, number of previous chemotherapy regimens $(P<0.001)$ and the time from diagnosis to mobilization $(P<0.001)$. Patients with unsuccessful mobilization had a lower median leukocyte and platelet nadir than patients with successful mobilization (0.2 vs $1.4 \times$ $10^{9} / /$ and 17 vs $\left.95 \times 10^{9} /, \quad P<0.001\right)$. The duration of leukocyte counts below $1.0 \times$ $10^{9} / /$ and platelet counts below $20 \times 10^{9} / /$ were longer $(P<0.001)$ among those whose mobilization did not succeed. The use of higher $\mathrm{CY}$ dose (higher than $3-4 \mathrm{~g} / \mathrm{m}^{2}$ ) for mobilization had also a negative impact $(P<0.001)$. When analyzing the use of IFN in the groups of successful and unsuccessful mobilization there were no differences in the median IFN administration time (10 and 12 months), or the median time interval from cessation of IFN therapy to mobilization (4 months for both groups). 
By multiple logistic regression the occurrence of post-mobilization sepsis, number of chemotherapy regimens and platelet nadir proved to have sufficient independent explanatory power to remain in the final model. The previous use of IFN ( $p=0.052)$ was almost of statistical significance, whereas the significance of the dose of CY was lost (Table 14).

Table 14. Variables in multiple logistic regression analysis of independent predictive power with regard to failure of stem cell mobilization

\begin{tabular}{llll}
\hline Variable & P-value & Odds ratio & $\mathbf{9 5 . 0 \% ~ C l ~ f o r ~ o d d s ~ r a t i o ~}$ \\
\hline $\begin{array}{l}\text { No. of different } \\
\text { chemotherapy }>1 \text { vs } 1\end{array}$ & 0.002 & 31.3 & $3.5-281.0$ \\
Use of IFN & 0.052 & 18.3 & $1.0-345.0$ \\
$\begin{array}{l}\text { Sepsis } \\
\text { Platelet nadir }\left(\times 10^{y} / \mathrm{I}\right)\end{array}$ & 0.040 & 10.1 & $1.1-92.9$ \\
\hline
\end{tabular}

\subsection{Comparison of short-acting and long-acting G-CSF as mobilizing agents in combination with chemotherapy in patients with lymphoproliferative diseases (II)}

\subsubsection{Mobilization and leukapheresis outcomes}

Mobilization and leukapheresis data in the subgroups of patients with MM, lymphoma and CLL are shown in Table 2 (II). There was no difference in median time to leukapheresis onset between the PEGFIL and FIL groups (10 days in each group). On the day of the first leukapheresis, the median blood CD34+ cell count and leukocyte count seemed to be higher in the FIL group than in the PEGFIL group, but the differences were not statistically significant. There were no significant differences in the median CD34+ cell counts at onset of leukapheresis between the different disease entities. However, the CD34+ cell count in patients with MM tended to be higher after PEGFIL mobilization compared to FIL mobilization: 123 vs $72 \times 10^{6} / / \quad(p=0.08)$, respectively.

In the PEGFIL group, the median leukapheresis yield was $4.9 \times 10^{6} \mathrm{CD} 34+\mathrm{cells} / \mathrm{kg}$ and was collected at a median of 1 (range 1-3) leukaphereses. In the FIL group the corresponding figures were $8.5 \times 10^{6} \mathrm{CD} 34+$ cells $/ \mathrm{kg}$ and $2(1-4)$ aphereses cycles. The target yield of CD34+ cells was obtained in all patients because only successful mobilizations were included in the analyses. The majority of the patients $(n=29)$ were treated with a PEGFIL dose of $12 \mathrm{mg}$. Due to the small number of patiens who received other doses (eight patients received $6 \mathrm{mg}$, one patient $18 \mathrm{mg}$ ) no meaningful comparison between the different dose levels is possible. However, there was a trend towards a higher CD34+ cell count when the leukaphereses were started in the PEGFIL $12 \mathrm{mg}$ group when compared to the PEGFIL $6 \mathrm{mg}$ group: median 74 (range $24.5-804.5)$ and $29(20-79) \times 10^{6}$ CD34+ cells/l $(p=0.015)$, respectively. The patients with mobilization failure, defined as a blood CD34+ cell count of less than $20 \times 10^{6}$ cells/l and/or unsuccessful harvesting, were not included in this analysis. During the study period there were two patients who failed mobilization $(5.3 \%)$ in the PEGFIL group (details given in Table 3 (II)). Between January 1996 and April 2005 there was a total of 251 patients who had been successfully mobilized with daily FIL and 18 patients $(7 \%)$ who had failed mobilization. The target yield of CD34+ cells was 
obtained following one leukapheresis cycle in 20 of $38(53 \%)$ patients in the PEGFIL group and in 27 of 76 (36\%) patients in the FIL group. For patients with MM aged under 60 years $(n=45)$, the aim was to collect sufficient stem cells for double transplantation ( $\left.\geq 6 \times 10^{6} / \mathrm{kg}\right)$. This target were obtained in $9(53 \%)$ and $16(57 \%) \mathrm{MM}$ patients in the PEGFIL and FIL groups, respectively.

To conclude, PEGFIL and FIL combined with chemotherapy seem to be equally efficient mobilization agents.

\subsubsection{High-dose therapy and autografting}

As of December 2006, 32 of the 38 patients in the PEGFIL group and all 76 patients in the FIL group had received HDT followed by ASCT (Table 2; II). There was no significant difference in the infused CD34+ cell dose between these two groups. Engraftment was similar in both groups following transplantation with no significant differences in the recovery of blood counts. The median time to discharge from hospital after transplantation was 17 days in the PEGFIL group and 14 days in the FIL group $(P=0.55)$.

\subsection{Comparison of single versus double ASCT (III)}

\subsubsection{Feasibility of double ASCT}

HDT supported by a single or a double blood stem cell autograft was well tolerated as upfront treatment of patients with MM up to the age of 70 and 61 years, respectively. There was only one transplant-related death in the single transplant group (1\%). As shown in Table 15, organ-specific toxicities were comparable between the first and second transplant procedure in the double ASCT group. The engraftment kinetics was similar after the first and second ASCT in the double ASCT group as well.

Table 15. Engraftment kinetics and organ-specific toxicities among patients in double ASCT group who underwent a first and a second ASCT.

\begin{tabular}{lll}
\hline & First ASCT & Second ASCT \\
\hline Days to neutrophil count $>$ 1, days, median (range) & $11(10-16)$ & $11(10-16)$ \\
Days to platelet count $>$ 50, days, median (range) & $18(13-60)^{\mathrm{a}}$ & $14(11-37)^{\mathrm{b}}$ \\
Days from tx to home, median (range) & $15(12-25)$ & $18(12-38)$ \\
Mucositis gr 0 / I / II / III & $5 / 15 / 5 / 2$ & $4 / 10 / 11 / 2$ \\
Gastrointestinal toxicity 0/ I / II / III / IV & $1 / 4 / 16 / 5 / 1$ & $0 / 7 / 16 / 2 / 2$ \\
\hline
\end{tabular}

${ }^{a}$ not available for one patient

${ }^{\mathrm{b}}$ not available for one patient and one patient`s platelets never reached $50 \times 10^{9} / \mathrm{l}$.

\subsubsection{Response rate}

After the initial debulking therapy there were no statistically significant differences between the single and double ASCT groups regarding overall response rates $(\mathrm{CR}$, VGPR and PR) before the first HDT: $67 \%$ (CR and VGPR 18\%) in the single and 59\% (CR and VGPR 7\%) in the double ASCT group. The rate of good responses increased with HDT (Table 16). Thus, the CR + VGPR rate increased from $18 \%$ to $72 \%$ and the CR rate from $4 \%$ to $41 \%$ in the single ASCT group. The respective figures in the double ASCT group were $7 \%$ to $70 \%$ (CR+VGPR) and $0 \%$ to $52 \%(C R)$. All patients in 
the double autografting group responded to HDT, but there were 3 patients $(4 \%)$ in the single ASCT group who did not.

Table 16. Response rates before and after single and double ASCT. numbers and \% in parenthesis where appropriate are given.

\begin{tabular}{llllll}
\hline $\mathbf{n}(\%)$ & $\begin{array}{l}\text { Single } \\
\text { Pre-Tx }\end{array}$ & $\begin{array}{l}\text { ASCT } \\
\text { Post-Tx1 }\end{array}$ & Pre-Tx & $\begin{array}{l}\text { Double ASCT } \\
\text { Post-Tx1 }\end{array}$ & Post-Tx2 \\
\hline CR & 3 & $30(41)$ & 0 & $7(26)$ & $14(52)$ \\
VGPR & 10 & $22(30)$ & 2 & $9(34)$ & $5(18)$ \\
PR & $36(49)$ & $17(23)$ & $14(52)$ & $9(34)$ & $8(30)$ \\
SD & $21(29)$ & 2 & $8(30)$ & 2 & 0 \\
PD & 3 & 1 & 3 & 0 & 0 \\
TRM & - & 1 & - & - & - \\
\hline
\end{tabular}

\subsubsection{PFS and OS}

The median follow-up for the alive patients from the time of the first transplant was 51 (4 - 138) months in the single ASCT group and 46 (10-78) months in the double ASCT group. The PFS seemed to differ, but not significantly between the single and double ASCT groups: the median PFS was $29(0-112)$ and $72+(5-75)$ months, respectively $(P=0.098$, Figure 1). The OS between the two groups did not differ significantly $(P=0.078)$ either, although there was a tendency towards longer survival in the double autograft group (Figure 1). The median survival was 60 (range $0-138$ ) months in the single ASCT group and 78+ (range 10 - 78) months in the double ASCT group. In the analyses there were 40 patients who would have been candidates (age <61 years) for double autografting which was not for different reasons performed (see page 55). The median PFS and OS for this group of 40 patients is inferior to the outcomes of the double-autografted patients: the median PFS and OS was $25(P=0.107)$ and 72 months $(P=0.193)$, respectively.

The observed tendency toward improved PFS and OS with double autografting disappeared when the median follow-up was prolonged to 68 months (range 5-150 months). All patients with newly diagnosed MM treated with HDT and ASCT in 19922006 were included in the follow-up analysis. There were 155 autografted patients including also the patienst in study IV; 125 in the single and 30 in the double autograft group. As of the end of year 2007, PFS in the single and double autografted groups were 29 and 30 months $(P=0.763)$ and $O S 71$ and 101 months $(P=0.116$; Figure 2$)$, respectively. 

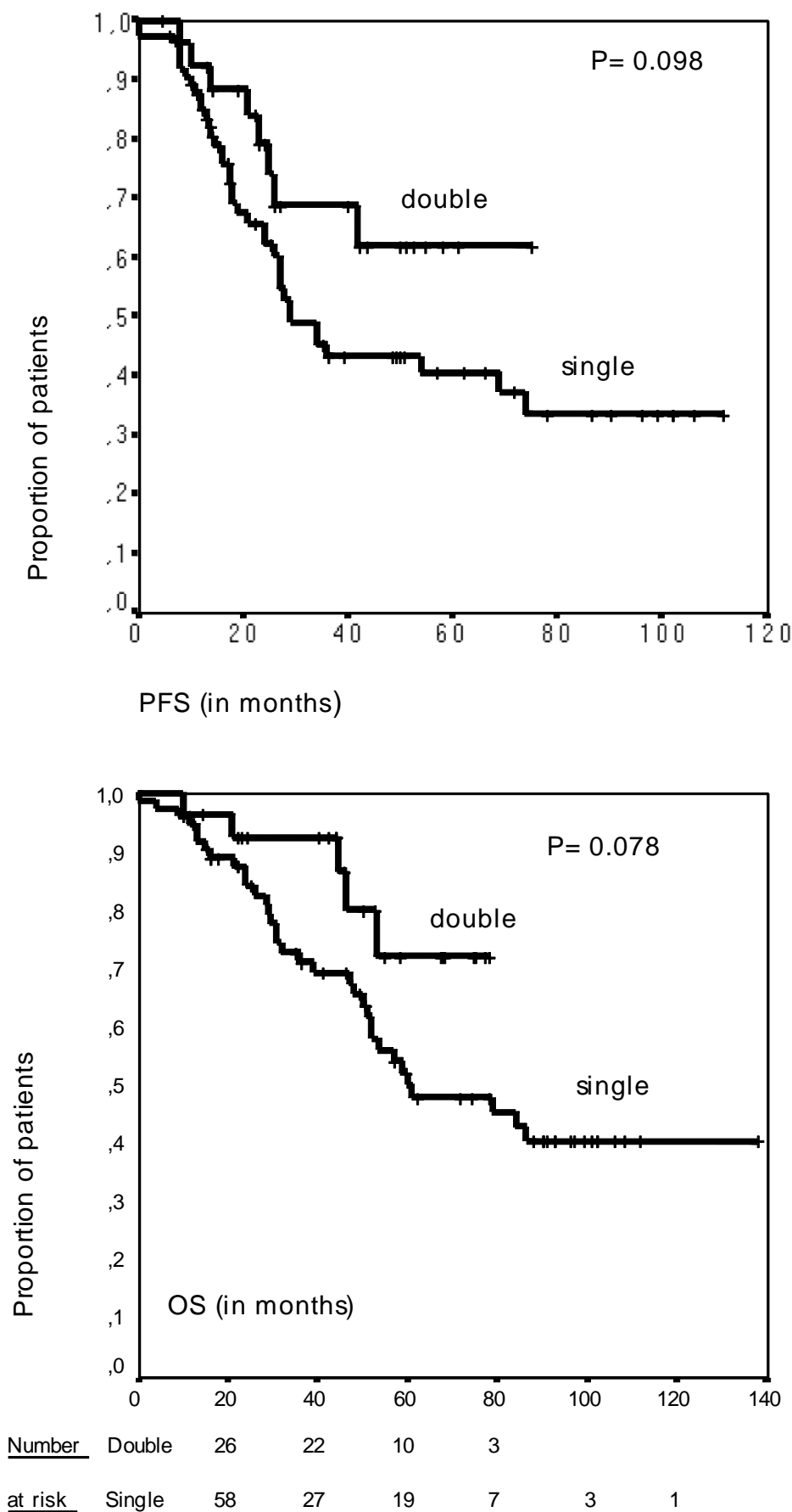

Figure 1. Median PFS and OS in the single and double ASCT groups. 

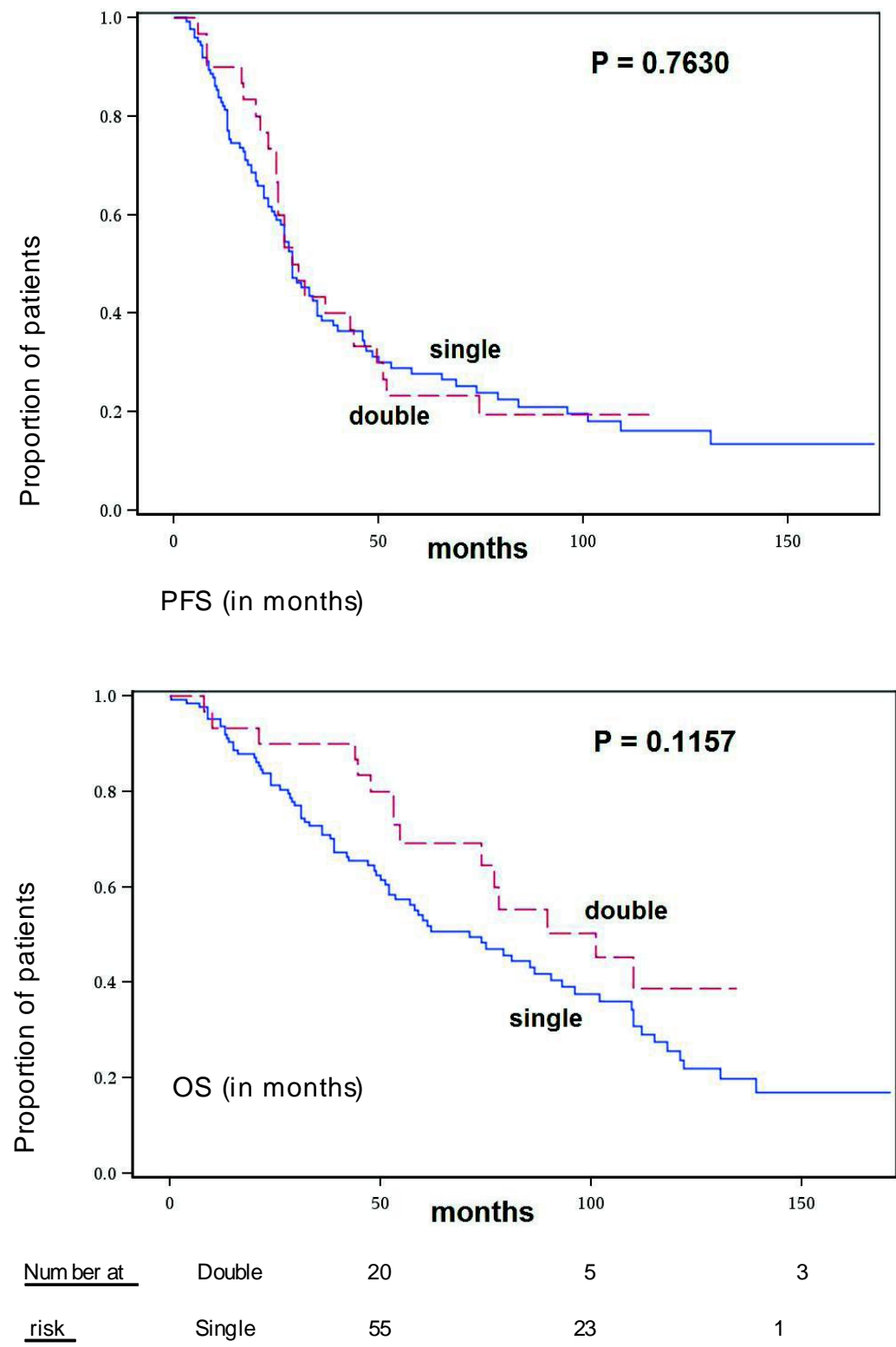

Figure 2. Median PFS and OS in the single and double ASCT groups with a follow-up of 92 in single and 88 months in double autografted group (Jaakkola et al, unpublished data). 


\subsection{MRD status after SCT, assessed by qASO-PCR (IV)}

\subsubsection{PCR negativity after autologous and allogeneic SCT}

qASO-PCR was used to detect the MRD level $3-6$ months after HDT and ASCT or alloSCT. The analyses were done for patients in $\mathrm{CR} / \mathrm{nCR}$ and among these patients a patient-specific probe for qASO-PCR analysis as available for 37 patients. In our hands, this gives a success rate of $86 \%$ to make a patient-specific probe for patients with MM.

In 21 patients (57\%) of the 37 patients with $\mathrm{CR} / \mathrm{nCR}$ after SCT the PCR transcript was not detectable $3-6$ months after transplantation with a median sensitivity of the PCR assay of $<0.002 \%$ (range: $<0.001-0.03 \%$ ). There was a difference in achieving PCR negativity between autologus and allogeneic transplantation: after ASCT, 16 patients (53\%) out of 30 transplanted patients were PCR negative (median sensitivity of PCR assay $0.005 \%$; range: $<0.001-<0.03$ ), whereas five out of seven allotransplanted patients $(71 \%)$ were PCR negative (median sensitivity $<0.016$; range $<0.006-0.03$ ).

\subsubsection{Impact of MRD status on PFS and OS}

To evaluate the prognostic significance of the quantitative PCR result, a cut-off level of $0.01 \%$ was chosen to divide the patients into MRD low/negative (sensitivity $\leq 0.01 \%$ ) and MRD positive $(>0.01 \%)$ groups. There were no significant differences in the main characteristics of the two groups (Table 1; IV). The median (and range) follow-up time for the alive patients was 48 (20-122) months, 65 (20-122) months for the MRD low/negative group and 39 (20-107) months for the MRD positive group, respectively. Seven patients died: three in the MRD low/negative (1 MM relapse) and four in the MRD positive group (all in MM relapse). The median PFS for the MRD low/negative $(n=21)$ and MRD positive $(n=16)$ groups was $70(10-122)$ and $19(4-85)$ months $(P=0.003)$, respectively, and the median $O S$ has not yet been reached $(P=0.101$; Figure 3). 

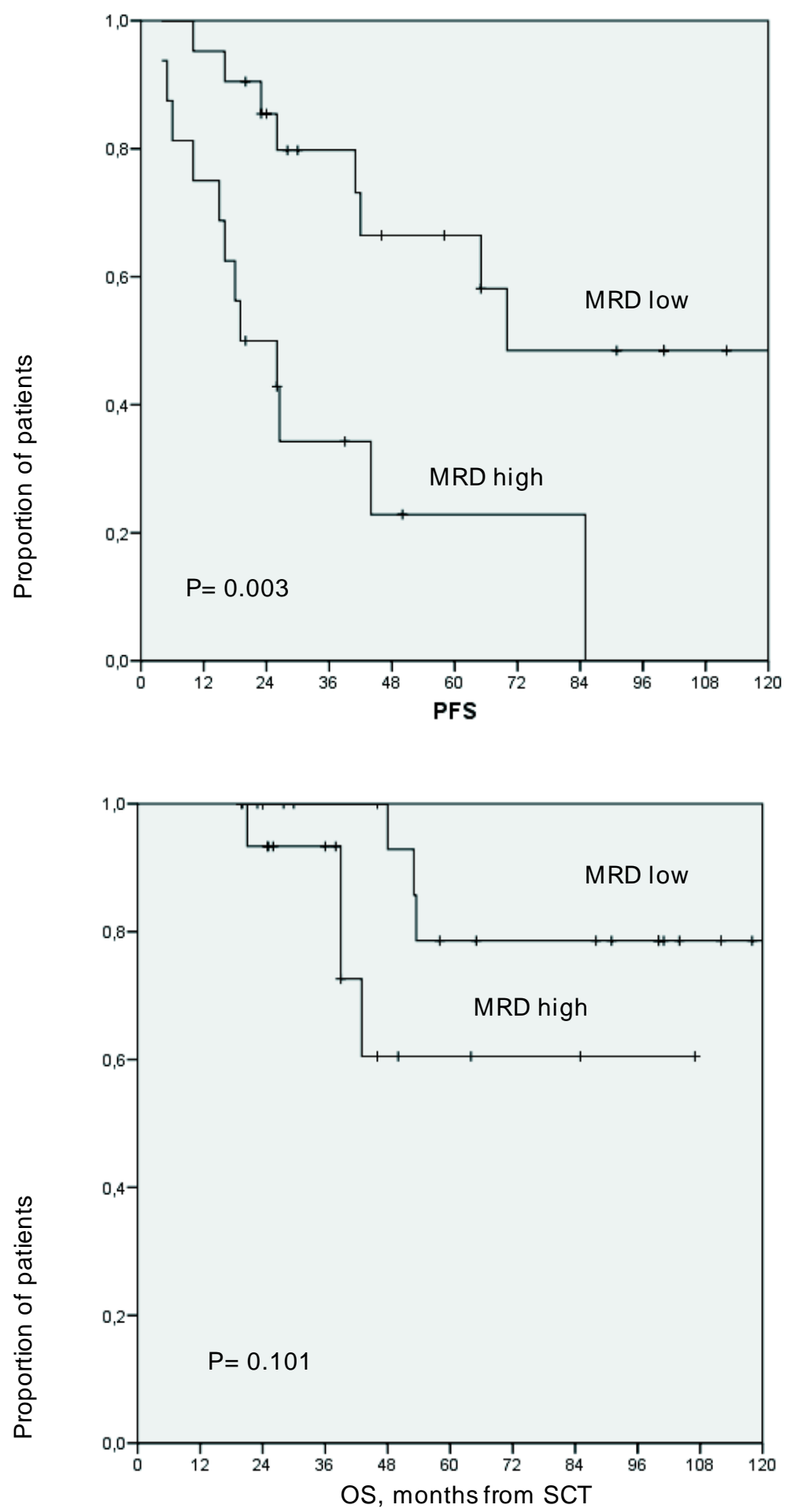

Figure 3. Median PFS and OS for MRD low/negative $(n=21)$ and MRD high $(n=16)$ groups. 


\subsubsection{Serial qASO-PCR monitoring}

The predictive value of the MRD level is seen among the 24 patients for whom serial PCR measurements were made (Figure 2; IV). Persistent low/negative MRD (a cut-off level of $0.01 \%$ ) was observed in 15 patients during the 10 to 122 months of follow-up and none of them had PD, whereas 11 out of 16 patients with persistent MRD positivity (follow-up 21 - 107 months) had PD. Intermittent low /negative MRD was observed in 4 patients with follow-up times of $48-112$ months and one has had PD.

\subsection{4 qASO-PCR vs IFE in MRD assessment}

All 12 nCR patients (IFE positive by definition) were also MRD positive. In contrast, there were four patients (16\%) who were IFE negative but MRD positive (Table 17). In these four patients, the disease relapsed at a median PFS of $22(16-44)$ months. The median PFS for the IFE negative and IFE positive groups was 65 (10 - 122) and 19 (4 - 85) months $(P=0.041)$, respectively. The median OS has not been reached in these groups ( $P=0.92$; Figure 4$)$.

Table 17. Distribution of IFE findings by MRD status assessed by qASO-PCR. IFE and qASOPCR were assessed at the same time 3-6 months after SCT.

\begin{tabular}{lll}
\hline & $\begin{array}{l}\text { IFE negative } \\
\text { (Number of patients) }\end{array}$ & $\begin{array}{l}\text { IFE positive } \\
\text { (Number of patients) }\end{array}$ \\
\hline MRD low/ negative & 21 & 0 \\
MRD high & 4 & 12 \\
\hline
\end{tabular}



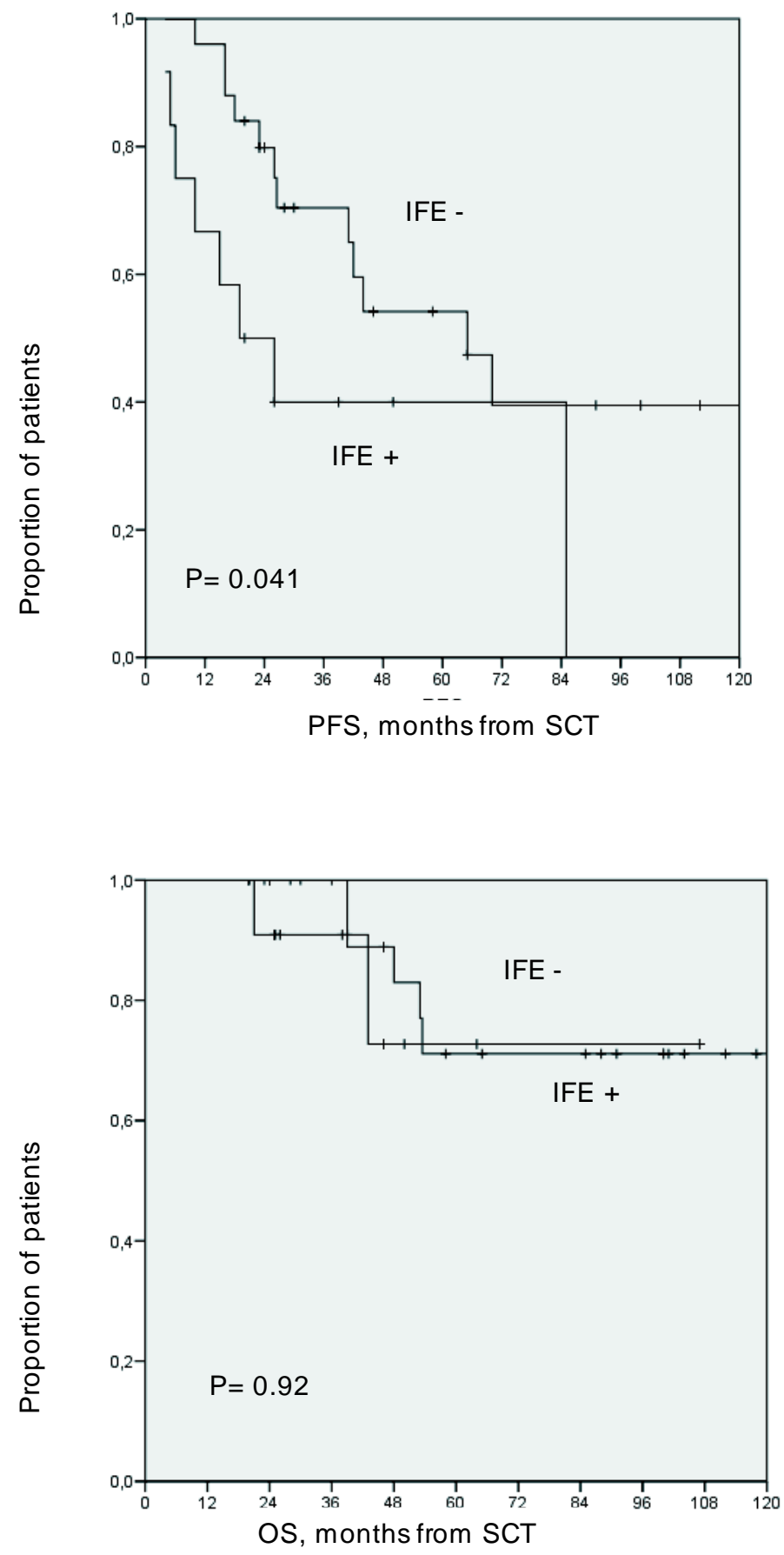

Figure 4. Median PFS and OS for the IFE negative and IFE positive groups. IFE was determined at the time of the PCR assessment 3-6 months after SCT. 


\section{DISCUSSION}

\subsection{Study population}

HDT and ASCT is currently a standard first-line therapy for patients with MM under 65 - 70 years of age. The present series of studies is based on four retrospective studies of prospectively collected data (I-IV). The participitans in all studies were adult (the youngest patient 37 years old) Finnish MM patients treated at the Turku University Central Hospital according to current treatment guidelines. The patient cohort of the four studies forms a typical homogenous group of MM patients who are in need of firstline therapy, i.e., cytoreductive initial therapy first, followed by stem cell mobilization and HDT + ASCT.

\subsection{Prediction of hematopoietic progenitor cell mobilization (I)}

Yields of hematopoietic stem cells vary greatly between patients and the optimal strategy to mobilize hematopoietic stem cells into peripheral blood to be collected with aphereses has not been fully defined. Current mobilization strategies consist of cytokines alone or in combination with chemotherapeutic agents. Mobilization with cytokines alone is well tolerated, but collection of sufficient numbers of stem cells to support transplantation may be difficult, especially in patients who have previously been treated with many intensive chemotherapy regimens (Haas et al. 1994). A significant proportion of cancer patients (10\% to $30 \%$ ) mobilize stem cells either poorly or not at all with the current approaches. Unsuccessful initial stem cell mobilization leads to costly additional mobilization attempts and may prohibit ASCT. Predicting the success of stem cell mobilization on beforehand would have important practical consequences. Studies on stem cell mobilization have often included heterogeneous groups of patients who have carried conflicting or unclear predictive factors.

In Study I we defined mobilization success on the basis of the peak CD34+ cell count in the blood based on the fact that the blood CD34+ cell count predicts accurately the harvested CD34+ cell yield (Haas et al. 1994, Remes et al. 1997). If the CD34+ peak in blood after mobilization is below $20 \times 10 /$ there is a high risk that an insufficient number of CD34+ cells will be harvested. However, adequate stem cell harvesting may be possible also with lower CD34+ cell counts $\left(10-20 \times 10^{6} / \mathrm{I}\right)$. The Nordic Stem Cell Laboratory Group has defined a blood CD34+ cell count of $20 \times 10^{6} / /$ to be a proper cut off value for initiating leukaphereses and with few exceptions we have followed this guideline (Johnsen1995).

Regarding the pre-mobilization factors that could predict the mobilization success we found that the parameters describing the amount of earlier treatment had the best predictive power, i.e. total number of chemotherapy cycles, total number of different chemotherapy regimens and disease duration from diagnosis to mobilization. In other words, the more treatment the patient has had, the poorer the CD34+ cell mobilization capacity will be. Previous studies have also demonstrated the negative impact of the amount of the earlier treatments on mobilization efficiency (Haas et al. 1994, Bensinger et al. 1995, Dreger et al. 1995, Koumakis et al. 1996, Engelhardt 1997). Previous exposure to cytostatic agents that are stem cell toxins, such as the alkylating agent 
melphalan, may be especially detrimental (Goldschmidt et al. 1996, Koumakis et al. 1996, Drake et al. 1997, Marit et al. 1998). With regard to the novel drugs, it is good to remember that use of lenalidomide seems to increase the risk to mobilization failure in MM patients (Kumar et al. 2007). The duration of treatment with stem cell toxin is also of importance (Tricot et al. 1995, Goldschmidt et al. 1996, Marit et al. 1998, Perea et al 200). It seems clear that the best stem cell yields can be obtained in an early treatment phase of MM. In our study 20 of 124 patients (16\%) had an unsuccessful mobilization. During the earlier years we tried to mobilize several patients with advanced MM with a number of failures but later we moved on to use ASCT primarily for newly diagnosed patients and mobilization failures have become rare.

Conflicting results have been published on other pre-mobilization factors predictive of stem cell mobilization efficiency, e.g., the time interval from the preceding chemotherapy before mobilization (Haas et al. 1994, Prince et al. 1996, Drake et al. 1997, Engelhardt et al. 1997), previous TBI (Bensinger et al. 1994, Haas et al. 1994, Dreger et al. 1995, Drake et al. 1997, Engelhardt et al. 1997) and BM infiltration (Tarella et al. 1993, Demirer et al. 1996, Prince et al. 1996, Engelhardt et al. 1997). In contrast to some previous studies (Demirer et al. 1996, Ketterer et al. 1998) BM infiltration did not appear to be a significant predictor of mobilization in our study, which agrees with some other studies (Goldschmidt et al. 1997, Marit et al. 1998). This discrepancy may be related to the fact that plasma cell infiltration is not uniformly distributed in the BM of MM patients. In our study the distribution of MM types was different in the successful and unsuccessful groups because of a higher proportion of light-chain disease in the successful mobilization group $(P>0.05)$. By univariate analyzes, the difference of MM type was not significant. In studies on stem cell mobilization the MM type has not been found to have significance, so in our study a higher proportion of light-chain disease in successful group seems to be a coincidence. Earlier observations suggest that mobilization failure is more common in patients with refractory disease (Goldschmidt et al. 1997) and that stem cells can be more readily collected from patients in CR or PR compared to patients with minimal or no response (Wahlin et al. 2004). Treatment response at mobilization did not have an impact on CD34+ cell yield in our study. Age and disease stage have sometimes been found to have a significant impact on CD34+ cell yield (Bensinger et al. 1994) but this was not the case in our analysis. The effect of previous TBI or the time from the preceding chemotherapy course could not be assessed in our patients.

In a randomized study (Cunningham et al 1998) a beneficial impact of post-transplant IFN on EFS in patients with MM was demonstrated, but this finding could not be confirmed (Barlogie et al. 2006a) and IFN maintenance is not commonly used any more. Before this confirmation we used IFN maintenance as a reasonable option of maintenance therapy after conventional chemotherapy. Thus, we had a patient cohort with IFN maintenance before stem cell mobilization. Previous use of IFN turned out to be a negative predictive factor for stem cell mobilization. There were no differences between the two groups in the median exposure time to IFN, nor were there any difference in the time interval from the IFN use to mobilization. IFN may have some toxic effect on bone marrow stem cells, which would be in line with its depressing effect on bone marrow activity and blood counts in diseases like the chronic myeloproliferative diseases (Schaar et al. 2005).

Among mobilization-related factors the mobilizing agents and their doses may be critical. CY plus G-CSF has been the most popular regimen for mobilization of bone 
marrow stem cells into the peripheral blood circulation in patients with lymphoproliferative diseases. CY-based regimens have yielded high numbers of CD34+ cells (Kotasek et al. 1992, Demirer et al. 1996, Goldschimdt et al. 1997, Wahlin et al. 2004). In study I, the mobilization chemotherapy consisted of CY, the dose ranging from $3-4 \mathrm{~g} / \mathrm{m}^{2}$ to $1.2-2.5 \mathrm{~g} / \mathrm{m}^{2}$. There was a significant tendency towards poorer mobilization as the CY dose grew: 14 of 20 patients with unsuccessful mobilization received $3-4 \mathrm{~g} / \mathrm{m}^{2}$ of $\mathrm{CY}$. This stands in conflict with observations where CY doses up to $7 \mathrm{~g} / \mathrm{m}^{2}$ have resulted in better progenitor cell yields (To et al. 1990, Kotasek et al. 1992, Boiron et al. 1993, Goldschmidt et al. 1997) but agrees with the nationwide Finnish study (Jantunen et al. 2003) where low-dose CY $\left(1.2-2 \mathrm{~g} / \mathrm{m}^{2}\right)$ plus G-CSF was as effective as higher doses of CY $\left(4 \mathrm{~g} / \mathrm{m}^{2}\right)$ plus G-CSF in terms of adequate progenitor cell mobilization and was associated with less toxicity and less need for supportive care.

A higher $C Y$ dose (from 3 to $4 \mathrm{~g} / \mathrm{m}^{2}$ ) causes deeper and more prolonged cytopenias and an increased incidence of fever and infectious complications (To et al. 1990, Prince et al. 1996, Wahlin et al. 2004). In our patients the effect of higher CY doses together with higher number of previous chemotherapy cycles (above 5 cycles) may have contributed to the rate of postmobilization sepsis episodes, to lower leukocyte and platelet nadirs and to a longer duration of cytopenias. Of course, our analysis has limitations because of the small number of unsuccessfully mobilized patients. However, by multivariate analysis, the occurrence of sepsis and low platelet nadir remained independent predictive factors for mobilization failure but CY dose did not. Our finding of the negative influence of sepsis on mobilization capability agrees with a previous report regarding the confounding effect of infection at the time of leukaphereses on stem cell collections (Johnson et al. 1995). Conflicting results of the significance of low platelet and low white blood cell counts have been published (Corso et al. 2000, Perea et al. 2001, Kuittinen et al. 2004). The significance of the low platelet count after mobilization agrees, however, with the common clinical observation: when blood leukocytes have recovered from mobilization therapy but platelets not, mobilization failure often ensues. We found both the low platelet nadir and the duration of blood platelet count below $20 \times 10^{9} / \mathrm{l}$ to be significant predictors of mobilization failure. Duration of deep neutropenia had a similar tendency. Prolonged platelet recovery to 50 $\times 10^{9} /$ has been found to impact negatively on progenitor cell mobilization by others, as well (Clark and Brammer 1998). The finding of a negative impact of deep and prolonged leukopenia and thrombocytopenia and of sepsis on mobilization capacity support our policy to use lower CY doses for stem cell mobilization in MM. If the mobilization attempt is performed in an early disease phase, adequate cell yields can be obtained with lower CY doses, which have been found effective and well tolerated also by others (Boiron et al. 1993, Jantunen et al, 2003). When stem cell mobilization is attempted after a few initial courses of chemotherapy, mobilization failures are fairly rare but do occur. When taking into account the possible adverse risk factors, both premobilization factors and those caused by mobilization therapy itself, it is possible on beforehand to be ready to use maneurvers that increase the likelihood of mobilization success. One of the most effective of these is to add plerixafor to the mobilization regimen if mobilization failure seems to be the risk. 


\subsection{Short- vs long-acting G-CSF as mobilizing agent (II)}

FIL, a short-acting G-CSF product, has been the most frequently used cytokine for mobilization. A number of studies have attempted to determine the optimal dosing and frequency of FIL therapy for mobilization. The doses have varied between 5 and 16 $\mu \mathrm{g} / \mathrm{kg}$ daily in one or two doses. However, higher doses were associated with increased toxicity and significant cost (Kröger et al. 2002b). The most common dose seems to be $5 \mu \mathrm{g} / \mathrm{kg}$ once daily continuing each day until the end of leukaphereses.

PEGFIL is an immunostimulant which functions as a pegylated G-CSF. It results in a longer duration of action with effective increases in the absolute neutrophil count and peripheral blood progenitor cell level for at least 1 week and it has been used increasingly for mobilization. In a study of MM patients receiving $4 \mathrm{~g} / \mathrm{m}^{2}$ of CY and 12 mg of PEGFIL, prompt leukocyte recovery and peripheral blood CD34+ cell peak (at day +12 following $C Y$ ) was seen and there was no delay in post-transplant hematopoietic reconstruction (Steidl et al. 2005). Using PEGFIL alone without chemotherapy for mobilization has also been successful in MM patients. A single dose of PEGFIL reduced the number of clinical visits and injections by substituting a single injection compared with daily FIL until completion of leukapheresis. The main finding in the case-matched study (II) was that a single dose of PEGFIL $(6-12 \mathrm{mg}$ ) as an adjunct to cytotoxic chemotherapy was capable of mobilizing a sufficient number of CD34+ cells for successful autografting in patients with different lymphoproliferative malignancies and its mobilization capacity was comparable to that of FIL. The rate of successful harvesting $(n=38)$ following chemotherapy plus PEGFIL mobilization has been $95 \%$; there have been 2 faílures. The corresponding historical failure rate with FIL mobilization was $7 \%$. However, it is not possible to draw any conclusions about the possible differences in failure rates because our study was neither prospective nor randomized.

Stem cell collection could be begun on day +10 in both PEGFIL and FIL groups. The time period was different for mobilization with PEGFIL (2005 - 2006) and FIL (1995 2005) and this might have impact on the results. However, the mobilization protocols have remained essentially the same during all these years for the majority of our patients. Most variation in both groups has occurred in the choice of mobilization chemotherapy for patients with lymphoma where different disease-specific chemotherapies have been used over the years. In addition, leukapheresis devices and collection procedures have been changed (collection volume, target of harvested cell numbers). This is a major limitation for making reliable comparisons on harvesting outcomes between the PEGFIL and FIL groups, but does not influence our main endpoint of the study, enumeration of blood CD34+ cells after mobilization at leukapheresis start.

In some studies there has been a tendency towards lower peak CD34+ cell counts in blood after PEGFIL mobilization when compared to FIL mobilization (Steidl et al. 2005, Fruehauf et al. 2007), but this is not the case in all studies (Bruns et al. 2006). After mobilization with PEGFIL it has been possible to start doing leukapheresis two to three days earlier than with FIL (Steidl et al. 2005, Fruehauf et al. 2007). In a number of previous studies of stem cell mobilization, a faster leukocyte recovery and an earlier occurrence of blood CD34+ peak has been found in PEGFIL treated patients compared with patients receiving FIL (Steidl et al. 2005, Bruns et al. 2006, Fruehauf et al. 2007). This difference was not seen in our study. In accordance with other previous 
studies (Steidl et al. 2005), the median blood CD34+ cell count 10 days after mobilization chemotherapy and the observed CD34+ cell peak count tended to be lower in the PEGFIL group than the FIL group, but this difference was not statistically significant. We did not, however, study stem cell kinetics: for practical reasons, the stem cells were collected and the patients discharged from hospital as quickly as possible. Thus, we may have missed the real peak value of blood CD34+ cells in some patients. Nor did we record for how long blood CD34 cell levels persisted above the collection threshold. In some earlier trials with PEGFIL, the impression has been that high levels of blood CD34+ cells are maintained over a period of several days (Isidori et al. 2005, Nosari et al. 2006) which allows a longer time window for stem cell collection.

Leukapheresis was started slightly earlier in our patients than has been reported in other studies. We could begin the leukapheresis on the same day +10 in both the PEGFIL and FIL groups whereas a delay of two to three days has been reported for FIL by others (Bruns et al. 2006, Fruehauf et al. 2007). In patients with lymphoma, the median start day of the leukaphereses was on day +12 , compared to $11-14$ days in the literature (Isidori et al. 2005, Nosari et al. 2006). These small differences in the time when to start leukaphereses for stem cell collection may be explained by differences in the timing of growth factor administration, which has varied from 1 to 6 days after start of chemotherapy in other studies (Isidori et al. 2005, Steidl et al. 2005, Bruns et al. 2006, Nosari et al. 2006, Fruehauf et al. 2007).

The optimal dose of PEGFIL for mobilization is unknown. In patients with chemotherapy-induced neutropenia, however, a single PEGFIL dose of $6 \mathrm{mg}$ once per cycle has been shown to be as effective as multiple daily doses of FIL $5 \mu \mathrm{g} / \mathrm{kg}$ (Holmes et al. 2002, Green et al. 2003). In studies on mobilization with PEGFIL, a single dose has varied between $6 \mathrm{mg}$ (Isidori et al. 2005, Kroschinsky et al. 2006, Nosari et al. 2006) and $12 \mathrm{mg}$ ( Steidl et al. 2005, Tricot et al. 2008). Our data suggest that $6 \mathrm{mg}$ of PEGFIL is highly effective and more cost-effective for mobilizing CD34+ cells than FIL. PEGFIL is well tolerated and has an adverse event profile similar to FIL (Beveridge et al. 2003, Kubista et al. 2003, Kroschinsky et al.2004): bone pain and headache are the main side effects.

Plerixafor, a newcomer in the mobilization field, is a strong inducer of mobilization of hematopoietic stem cells from the bone marrow to the blood. In studies of patients with MM and lymphoma, more CD 34+ cells were mobilized after administration of plerixafor plus G-CSF than after G-CSF alone: the median increase in cell yield was $3.0-4.4$ fold (Flomenberg et al. 2005, Calandra et al. 2008).

Although chemomobilization is widely used, no strategy can yet be considered as standard. For patients with MM who are candidates for ASCT and who have not received initial therapy with lenalidomide, mobilization with G-CSF alone is often sufficient for a single ASCT but may not be enough for a double (tandem) ASCT. In spite of a failed mobilization with the first attempt a second try may be successful. In the future, advances in effective mobilization of stem cells will permit a greater proportion of patients to benefit from ASCT. 


\subsection{Double vs single ASCT (III)}

The superiority of ASCT over conventional chemotherapy has been shown in randomized studies: ASCT has resulted in increased response rates and prolongation of EFS and OS (Attal et al. 1996, Child et al. 2003, van de Velde et al. 2007). The most apparent reason for improvements in the treatment outcome is the increased CR rate made possible by HDT. CR is a rare event after conventional chemotherapy but not with HDT. The increased CR rate is the single most significant factor for improved EFS and OS compared to conventional chemotherapy (Harousseau et al. 1995, Attal et al. 1996, Child et al 2003 ). At the time when CR criteria did not include immunofixation negativity the CR rate varied from $22 \%$ to $75 \%$ (Attal et. al 1992 , Cunningham et al. 1994, Björkstrand et al. 1995, Harousseau et al. 1995) and when they did, from $14 \%$ to 26\% (Attal et al. 1996, Weaver et al. 1998, Barlogie et al. 1999, Lemoli et al. 2000). The CR rates after double autografting and including immunofixation negativity have varied from $30 \%$ to $55 \%$ (Vesole et al. 1996, Weaver et al. 1998, Barlogie et al. 1999, Lemoli et al. 2000, Harousseau 2002). Our observations agree with these figures: in the double ASCT group the CR rate after the first ASCT was $26 \%$ and increased to $52 \%$ after second ASCT.

In addition to response to HDT there are also other significant factors contributing to an improved treatment outcome after HDT, such as a lower beta-2-microglobulin level (Barlogie et al. 1993, Fermand et al. 1993, Vesole et al. 1996), short time between chemotherapy and HDT (Barlogie et al. 1993, Vesole et al. 1996, Fermand et al. 1998), and younger age (Vesole et al. 1996, Harousseau and Attal 2003). On the other hand, an unfavorable karyotype carries an especially poor prognosis (Barlogie at al. 1999, Desikan et al. 2000). MM patients in the most favourable prognostic group (52\% rate of five-year continuous $\mathrm{CR}$ ) have the following characteristics: no chromosome 13 abnormalities, low beta-2-microglobulin concentration in the serum $(<2.5 \mathrm{mg} / \mathrm{L})$ and short standard chemotherapy period before HDT ( $<12$ months; Desikan et al. 2000). One quarter of these patients have an EFS for more than 5 years and no further relapses after 7 years, suggestive even possible cure for these patients. A subpopulation of patients with a combination of the most favorable prognostic factors may be cured with double HDT and autografting (Tricot et al. 2002).

Double ASCT can produce better long-term outcomes than single ASCT, at least in patients who have not reached CR or VGPR after the first autografting (Attal et al. 2003). The authors of the IFM 94 trial suggest that the difference in projected survival between signle and tandem ASCT does not correlate with improved response rates but rather with a longer duration of responses. This may explain why differences in survival are not apparent with shorter follow-up times in other randomized studies of tandem ASCT. In our study, the PFS differed between single and tandem ASCT, but not significantly, at the time of our first analysis when we had a median follow-up of 4 years, but at the time of our second analysis at a median follow-up time of 5.7 years, the small difference in PFS had disappeared and the median PFS was identical for the single and double autografted groups. The observed tendency towards longer survival in the double ASCT group had also decreased with our longer follow-up time. These findings highlight the need for sufficiently long follow-up times in diseases like MM characterized by late relapses.

Today it seems reasonable to consider tandem ASCT for patients who do not have at least VGPR after the first ASCT. It may be advantageous to collect enough stem cells 
to allow patients under 65 years to undergo two transplantations: the second ASCT may be needed either for tandem ASCT or to treat a later relapse.

\subsection{Depth of CR in MM (IV)}

Achievement of $\mathrm{CR}$ as a surrogate of prolonged survival can be regarded as the target of initial therapy for MM, whenever possible. For this purpose HDT with autografting is superior to conventional therapy and double autografting may further improve the CR rate (Weaver et al. 1998, Barlogie et al. 1999, Harousseau 2003) and long-term outcome. Clinical remission is usually not sufficient to ensure permanent cure and remission also at a deeper level should be achieved. Molecular remissions are possible with single or double autografting (Björkstrand et al. 1996, Martinelli et al. 2000 ) but more often with allogeneic transplantation (Majolino et al. 1998, Corradini et al. 1999). Allogeneic stem cell transplantation has, until recently, been regarded as the only treatment that gives MM patients a chance for cure (Björkstrand et al. 1996). However, the median OS at 7 years and DFS at 6 years for CR patients are comparable for patients treated with either double autotransplantation (Tricot et al. 2002) or allotransplantation (Gahrton et al. 1999), suggesting that double autografting may also have curative potential in patients with favorable prognostic signs. Allografting may be superior for younger patients with an unfavorable prognosis. While a graft-versus-myeloma effect has been shown to exist in myeloma (Tricot et al. 1996, Verdonck et al. 1996), it remains to be seen if autografting followed by RIC-allografting improves the treatment outcome for patients with unfavorable prognostic signs.

Sets of patients with equally good CR rates on conventional chemotherapy as on HDT and ASCT have experienced similar long-term EFS and OS (Barlogie et al. 2006). Not only the achievement of CR but sustainability of CR for at least three years have emerged as a new surrogate marker for long-term clinical outcome for high-risk patients (Barlogie et al. 2008). At present, a new suggestion is that achievement of CR (or nCR) should be the target of first-line therapy in MM. With the introduction of novel drugs (thalidomide, bortezomib and lenalidomide) and drug combinations, achievement of CR in myeloma with first-line therapy has become a reality, only seldom seen in the era of conventional treatments. Even higher remission rates after ASCT have been recorded when $\mathrm{CR}$ has been achieved with the novel drugs used for the initial treatment of MM preceding ASCT (Attal and Harousseau. 2007, Bensinger et al. 2008). The depth of the response, i.e., assessment of MRD also with qASO-PCR, may play an important role in future for comparing the efficacy of different treatment options.

There are, nevertheless, several studies according to which an increased CR rate has not resulted in extended survival (Dingli et al. 2007, Durie 2010). CR is a good measure of the short-term efficacy of a given therapy and often a useful surrogate for survival as well. It must be kept in mind, however, that many patients live a long life with chronic MM without achievement of CR. Thus, the general aim of therapy should be prolongation of survival (Durie 2010). For patients for whom achieving CR is a surrogate for prolonged survival the depth of response may be critical: the less the patient has residual disease, the longer the survival may be.

The new drugs, mainly thalidomide, lenalidomide and bortezomib, as well as the increased experience with allo-RIC will compel the MM community to rethink the role of 
ASCT. It is not known if patients achieving CR on conventional therapy ultimately benefit from ASCT.

\subsubsection{Use of qASO-PCR for MRD assessment}

MRD monitoring can be used in different clinical situations, including monitoring of the depth of good responses to therapy, sequential monitoring to predict relapse and assessment of the purity of stem cell harvests after manipulation (Bacher et al. 2008). In this study the main focus was on monitoring the depth of response and on evaluation of the MRD level to examine the impact of MRD on the prognosis of the patient. The main finding was that among the $\mathrm{CR} / \mathrm{nCR}$ patients the molecular remission rate measured with the sensitive qASO-PCR was lower after ASCT (53\%) than after alloSCT (71\%). Secondly, a threshold level of $0.01 \%$ in the qASO-PCR assay was found to be a useful cut-off limit for dividing patients into MRD low/negative $(\leq 0.01 \%)$ and MRD positive $(>0.01 \%)$ groups, since the long-term outcome of these groups differed. MRD negativity by PCR after stem cell transplantation was found to be a significant predictive factor for prolonged PFS; it was also associated with prolonged OS, but not statistically significantly. The median PFS in the MRD low/negative and MRD positive groups was 70 and 19 months, respectively ( $P=0.003)$; the median OS has not been reached $(P=0.10)$. This finding is consistent with the assumption that not only $\mathrm{CR}$ but also the depth of the CR are important predictors of the morbidity and mortality of MM patients.

Most of the studies thus far on the use of PCR to assess MRD in MM has had a small number of patients and only qualitative or non-qASO-PCR techniques have been used. The few available previous study results on the molecular responses assessed with non-qASO- PCR techniques after ASCT and alloSCT are in agreement with our results. Thus, molecular remission rates between 7 and $16 \%$ after ASCT and 50 to $70 \%$ after alloSCT have been reported in series of 13 to 14 patients (Davies et al. 2001, Rasmussen et al. 2004), but in two patient series of single or tandem ASCT, molecular remissions were not found in any patient when assessed with a most sensitive qASOPCR assay (Corradini et al. 1999, Bakkus et al. 2004). Already early studies reported that molecular remissions are important for survival: the relapse-free survival after alloSCTwas 110 months among patients with molecular remission and only 35 months if molecular remission had not been attained $(P<0.005$; Rasmussen et al. 2004). Bakkus et al (2004) measured tumor load with a quantitative ASO-PCR in a larger series of 67 patients at $3-6$ months after ASCT and reported a prognostically useful cut-off value of $0.015 \%$ to divide patients into good and bad prognosis groups; the median PFS was 64 months and 16 months, respectively $(P=0.001)$. Moreover, an important finding in their study was that quantitative PCR may define a patient with $C R$ as having a poor prognosis and a patient with PR as having a good prognosis, and this implies that the classical measure of disease activity, the amount of paraprotein, is not an accurate measure of the remaining tumor load post ASCT. With the cut-off value of $0.01 \%$ in our study we could also divide the patients into two prognostically differing groups with significant difference in PFS and tentatively also in OS. The Spanish PETHEMA group also used an MRD threshold of $0.01 \%$ and defined two risk groups with significantly different PFS (34 vs 15 months) (Rawstron et al. 2008). The preliminary results by the Arkansas group demonstrate a high molecular rate (82\%) in 22 patients who achieved $C R$ with their total therapies and the patients with a molecular CR had also a significant prolongation in time to progression (Tricot 2007). 
These results have raised suggestions that the traditional definition of $C R$ is not sufficient and that molecular CR should be the new goal for MM therapy. However, it is clear that neither does molecular remission guarantee that patient will be free from relapse, much less that he is cured (Van de Velde et al. 2007).

Quantitative ASO-PCR offers a possibility for sequential monitoring of MRD and treatment tailoring. Usually, molecular remission is achieved within $3-6$ months after transplantation, but it can take more than one year posttransplant, especially after allografting where the graft-versus-myeloma effect may take time (Rasmussen et al. 2004, Bacher et al 2008). A 2-log reduction in clonogenic cells in the bone marrow has been recorded between an active disease phase and the best response posttransplant. $A$ rise in the number of myeloma cells by PCR quantification predicts relapse (Cavo et al. 2000, Corradini et al. 2002). In the allogenic setting, serial molecular measurements of the state of the bone marrow of 48 patients showed that the 5-year risk of relapse was $0 \%$ if there was durable PCR negativity, $33 \%$ if there was intermittent PCR negativity and $100 \%$ if PCR was positive with regard to myeloma cells (Corradini et al. (2003).

Quantitative molecular follow-up can also be used to tailor posttransplant immunological interventions after allogeneic SCT (Cremer et al. 2000, Cavo et al. 2000, Martinelli et al. 2000). The main focus in our study was the predictive value of the immediate posttransplant qASO-PCR result and serial PCR assessments were done only for a little more than half of the patients. Thus, no solid conclusions about the usefulness of serial measurements can be done but, there was a tendency towards a lower progression rate if PCR negativity persisted. qASO-PCR has also been used to detect tumor cell contamination in stem cell harvests; harvests from peripheral blood are less contaminated than from bone marrow (Ladetto et al. 2002, Zhou et al. 2003).

The sensitivity of detection of MRD by PCR techniques has improved along with technical improvements. The process has developed from qualitative PCR to semiquantitative ASO-PCR and, finally, to the most sensitive quantitative real-time ASOPCR techniques that have a maximal sensitivity of $10^{-5}$ to $10^{-6}$ (Blade et al. 1998, Verhagen et al. 2000, Bacher et al. 2008). The amount of clonogenic myeloma cells differs significantly between paired samples from peripheral blood and bone marrow: the number is, understandably, much lower in peripheral blood and the tumor load detected by qASO-PCR can vary over a range of 3 logs (Corradini et al. 2002). For MRD studies bone marrow samples are clearly to be preferred. In our study, real-time quantification of the clone-specific $\mathrm{IgH}$ rearrangement was performed on DNA samples using individual allele-specific oligonucleotide primers designed for each patient to match the hypervariable CDR3 region of the sequenced IgH-gene. This technique allows us to perform the PCR test in most patients with B-cell malignancies with a limited number of probes. Even if technically demanding and time consuming, the advantages of real-time qPCR are high accuracy, reproducibility and reduced work compared to earlier PCR methods. As the technique has a detection limit of one clonal cell in $10^{5}$ to $10^{6}$ normal cells, the cut-off level of 0.01 to $0.015 \%$ can be regarded as an appropriate threshold for PCR negativity vs positivity, as used by others, as well (Bakkus et al. 2004, Rawstron et al. 2008). A disadvantage of the quantitative ASO$\mathrm{PCR}$ technique in $\mathrm{MM}$ is that it is usually possible to construct patient-specific probes to only $60-80 \%$ of the patients (Verhagen et al. 2000, Ladetto et al. 2002, Bakkus et al. 2004, Rawstron et al. 2008). In the present series, the figure was $86 \%$. Another apparent drawback of the technique is that, due to the patchy infiltration of myeloma 
cells in the bone marrow, a single bone marrow aspirate for MRD analysis may give a false negative result (Verhagen et al. 2000, Bacher et al. 2008). The considerable patient-specific variation of the PCR assays must be borne in mind.

\subsubsection{Comparison between PCR and IFE}

The traditional methods for assessing the response to myeloma treatment are protein electrophoresis and IFE (Bacher et al. 2008). In the post-ASCT setting it has been shown that the patients in CR defined by a negative IFE have a highly significant EFS and OS benefit at 5 years compared to patients whose electrophoretic result is negative but the IFE result is positive (Zent et al. 1998). Interpretation of electrophoretic strips may, however, be difficult because of the new oligoclonal bands or isotype switch which are fairly common after HDT (Zent et al. 1998, Fenk et al. 2004). Quantitative PCR evaluates the number of myeloma cells while IFE gives an estimation of the amount of paraprotein. This is the probable cause for the higher predictive value of qASO-PCR compared to IFE. While Bakkus et al. (2004) reported a significant difference in PFS between the good and poor prognosis groups based on qASO-PCR results, they found no such a difference between patients who achieved a CR based on IFE and those who did not. Achieving CR was not an independent risk factor in their study, which suggests that estimation of number of viable myeloma cells with qPCR is a better way to evaluate the response than paraprotein quantification. IFE negativity (which equals CR by EBMT criteria) results in better long-term outcome than IFE positivity (Guikema et al. 1999, Lahuerta et al. 2000). Lahuerta et al (2000) analysed retrospectively $344 \mathrm{MM}$ patients treated with HDM + ASCT. The outcome of patients who were in CR and IFE was also negative was significantly better than those patients who were in CR, but IFE was positive (median EFS 46 versus 30 months, $\mathrm{P}=0.004$ and median $\mathrm{OS}$ not reached compared with 56 months, $\mathrm{P}=0.0006$, respectively). In the present study qASO-PCR was a more sensitive method than IFE for detecting MRD. Although the median PFS differed significantly (65 and 19 months, respectively; $P=0.041$ ) between IFE negative and IFE positive patients, the difference was not as clear as between the PCR negative and PCR positive patients $(P=0.003)$.

\subsubsection{Comparison between PCR and flow cytometry}

In addition to PCR, immunophenotyping with flow cytometry is another sensitive tool to assess MRD in MM. The myeloma-specific cell surface antigen pattern offers an efficient method to quantify low levels of myeloma cells with a maximum sensitivity of $10^{-4}$ (Rawstron et al. 1997, Davies et al. 2001, Bataille et al. 2006, Bacher et al. 2008) As the flow cytometry technology has developed, 8-color flow cytometry has been introduced and similar sensitivity levels as for ASO-PCR can be reached (Paiva et al. 2008). The immunophenotype of myeloma cells changes in the majority of patients during therapies and down-regulation of aberrantly expressed antigens may jeopardize MRD detection by flow cytometry. To avoid misinterpretations a wide panel of monoclonal antibodies must be used (Gupta et al. 2009). Some of the advantages of flow cytometry include high speed which makes it suitable for routine use and its wide applicability to nearly $100 \%$ of MM patients.

In the present study, we did not compare the assessment of MRD with qASO-PCR and flow cytometry, but some comparative studies have been published by others: qASOPCR has been more sensitive, but, in general, MRD levels detected by both methods 
have correlated strongly (Rawstron et al. 1997, Rawstron et al. 2008). In the PETHEMA Group study, an MRD threshold of $0.01 \%\left(10^{-4}\right)$ was used and two risk groups with differing PFS could be identified by using either PCR or flow cytometry (Rawstron et al. 2008). The two risk groups were nearly identical regardless of which technique was used. In a Spanish study, the MRD status at day 100 after ASCT measured with multiparameter flow cytomety was the most reliable prognostic factor: PFS and OS were significantly longer if there was no MRD (Paiva et al. 2008). 


\section{SUMMARY AND CONCLUSIONS}

High-dose therapy supported by ASCT is the current standard of care for first-line treatment of patients with newly diagnosed MM. The median survival time of patients with MM has increased from 3-4 years with conventional chemotherapy to the current expected survival of $5-6$ years. With optimal use of novel drugs - thalidomide, lenalidomide and bortezomib - this outcome may still improve. Regardless of the position of ASCT as the standard of care of MM, there are many unresolved issues with the current treatment. These include prediction of failure of stem cell mobilization, use of short vs long acting G-CSF, administration of high-dose therapy once vs twice and the possible importance of obtaining not only a clinical or immunophenotypic remission with ASCT but a high-quality remission without MRD. These were the topics of the present studies. The studies were retrospective but the data were prospectively collected for later analyses.

\subsection{The predictive factors of stem cell mobilization failure}

Stem cell mobilization is a prerequisite for HDT plus ASCT. Successful mobilization is much more common in newly diagnosed MM than in lymphomas and CLL, where ASCT is not a part of front-line therapy and the patients have typically received significantly more treatments before mobilization. However, some $5 \%$ to $10 \%$ of patients with newly diagnosed $\mathrm{MM}$ are mobilization failures. A reliable prediction of mobilization failure would be of great help for identifying before hand those patients in need of more efficient mobilization methods and for avoiding the costs of remobilization attempts. One of the most recent possibilities to increase the likelihood of successful mobilization in the poor-to-mobilize subjects is the use of plerixafor, a new drug in this field.

In study I we we searched for predictive factors of mobilization failures in patients with early disease and patients with late-stage disease. We identified some factors associated with poor mobilization before mobilization (amount of earlier chemotherapy and previous use of interferon maintenance therapy) and during mobilization (nadir of thrombocytopenia, duration of thrombocytopenia and sepsis at onset of mobilization). The presence of these factors, together with some other factors presented in literature, can be used for selecting patients for more efficient mobilization attempts. According to the literature some other factors are associated with poor mobilization, like previous mobilization failure, a short time from the preceding chemotherapy before mobilization, febrile neutropenia and prolonged platelet recovery. We also identified previous use of IFN as a negative predictive factor, but since IFN is no longer used for maintenance treatment in MM, this novel observation is more of academic than clinical interest.

\subsection{Short-acting or long acting G-CSF for mobilization?}

Short-acting G-CSF (filgrastim; FIL) has been the standard agent for mobilization of autologous stem cells in MM and other diseases alone or combined with chemotherapy. It is used as subcutaneous injections usually once daily. From the patient's point of view, the new long-acting pegylated derivative of filgrastim (PEGFIL) offers a 
convenient and practical way for mobilization. It is administered as one subcutaneous injection. The single dose varies from 6 to $12 \mathrm{mg}$.

Our study comparing PEGFIL and FIL was a case-controlled study: for every PEGFIL treated patient there were two control cases from our data base. Study subjects had different lymphoproliferative diseases, i.e. MM, lymphomas and CLL. The main finding was that PEGFIL was an equally good mobilizing agent as FIL for all lymphoproliferative diseases, including MM. This result is in agreement with previous studies and has changed our mobilization therapy policy. We have moved to administration of PEGFIL as a single dose after chemotherapy since year 2007. This is very practical for the ward staff and easy for the patients.

\subsection{Double or single ASCT?}

The literature does not identify studies to answer unequivocally the question of whether two successive ASCTs with HDM conditioning as up-front therapy for patients with MM are an appropriate treatment or not. The French 94 IFM Study has the longest followup and an OS benefit was documented for patients with a worse response than VGPR to the first autograft. A similar finding was reported by the Italian Study Group.

Our study (III) was a retrospective survey where patients with double transplantation were compared with those receiving a single transplantation. There are some significant limitations to this study. First, it was not randomized but rather an observational retrospective study. However, an observational study serves as a clinical quality assessment of treatment strategies used for our patients and the study reflects also the results of everyday patient care. There is, of course, a selection bias when we choose patients for double autografting. The patients must not have serious comorbidities or a poor performance status. Also, the treatment periods do not overlap, and the use of historical controls may suffer from renewals in minor changes of treatment policies.

Our analysis with a roughly 4-year follow-up time of alive patients, however, demonstrated a clear-cut tendency towards prolonged PFS and OS for those patients who had received double autografting. When the follow-up time had doubled from that in the original publication (III), the survival curves joined. This highlights the importance of a sufficiently long follow-up time for diseases that may relapse late and have median survival figures of $5-10$ years or even more. A common drawback of the trials of MM treatment is the short follow-up, too short to show the ultimate outcome of the patinets. On the basis of our own analysis and other studies in literature we have abandoned our earlier policy where we performed a double transplantation for all eligible patients below the age of 60 years and moved to a policy where a tandem transplantation upfront is performed only for the patients with a worse response than CR or nCR to the first transplant.

\subsection{Importance of depth of complete response after stem cell transplantation}

$\mathrm{CR}$ is a rarity after conventional chemotherapy. Only after introduction of HDT supported by stem cell transplantation has the rate of CR increased substantially. It is 
well known that $\mathrm{CR}$ is a common finding after allogeneic transplantation and this treatment modality is the only curative treatment option in MM available currently. A CR rate up to $50 \%$ is possible with ASCT or with combinations of the novel MM drugs. In studies on HDM and ASCT the importance of CR for the long-term outcome has been clearly demonstrated and CR has been set as a new target for MM treatment. There are some studies suggesting that a more appropriate target would be a deeper CR, i.e. CR without MDR. The most sensitive method to assess MRD is quantitative patient-specific PCR (qASO-PCR). We used this method to study the depth of response in our transplanted patients (after either ASCT or alloSCT) who were in CR or nCR (IFE positive) according to EBMT criteria after ASCT. First, we observed a higher rate of MRD negativity after allogeneic SCT than after autologous SCT. Second, we demonstrated a significant long-term outcome benefit for the patients who did not have MRD compared to those who had MRD. This finding together with other similar reports in the literature supports the importance of assessing MRD of CR patients at least for research but also in situations where early intervention to combat MRD is feasible, e.g., donor lymphocyte infusions after alloSCT. 


\section{ACKNOWLEDGEMENTS}

The work of this thesis was carried out at the Department of Medicine, Turku University Central Hospital during the years $2005-2011$.

I express my gratitude to Professor Jorma Viikari, Head of the Department of Medicine for the encouraging and research-minded atmosphere at the department. I am privileged to work under his leadership.

I thank sincerely Professor Emerita Auli Toivanen, former Head of the Department of Medicine, for her warm and positive attitude at the time of my specialization in internal medicine. Her wise and practical advice is permanent spiritual capital for me.

I express my deepest gratitude to my principal supervisor, Professor Kari Remes, for his encouragement and endless patience. I can never thank him enough. Under his guidance I have had a privilege to make myself familiar with the stimulating world of hematology. He has always had time to me - to help and to fortify my determination to get the job done. His profound knowledge of hematology and his optimistic attitude to life make me humble. During these years he has always upheld his belief in my possibilities and in the value of this study. Yes, he made the impossible possible.

I own my sincere gratitude to my second supervisor, Docent Maija Itälä-Remes, for her continuous support for my work. Her valuable comments helped me to improve this thesis. I greatly admire her scientific enthusiasm and common sense. It is a great pleasure to work with such an intelligent and sensible woman.

I express my deepest gratitude to the official reviewers of this thesis, Professor Anders Waage and Docent Marjaana Säily, for their kind and constructive criticism which markedly improved this thesis. I highly appreciate their skilful comments. I warmly thank Professor Anders Waage for devoting so much of his valuable time to my thesis. I was very fortunate to get him to review this work. His professional advice and fruitful suggestions have opened my eyes to new aspects on the treatment of MM. I am grateful from all my heart to Docent Marjaana Säily for her thorough scrutiny of my work and only hope reviewing my study did not destroy totally her Christmas.

I thank Docent Tarja-Terttu Pelliniemi, former Head of the Department of Laboratory. I am grateful to her for such expert guidance. I appreciate her passionate attitude toward hematology and her long and profound experience. It has been a privilege to have a teacher like her. She always found the time and willingness to help and guide me.

I am very grateful to Auvo Rauhala, Medical manager of Vaasa Central Hospital, M.D., $\mathrm{PhD}$, for his expert statistical advice. Without him I would have been in trouble with the statistical analyses of this thesis. He has spoiled me, since he made me used to getting quick and logical answers to questions relying on unclear data. He is a kind person and has a great sense of humor. I value highly our friendship.

I owe my sincere thanks to Docent Veli Karisto and Docent Vesa Juvonen, Laboratory of molecular genetics TYKSLAB. I can only admire their intelligent and logical way in doing science. I have always been impressed by their intelligence and diligence. I am grateful to their patience and energy when they had to explain me the mysteries of 
PCR over and over again. Their altruistic guidance has been indispensable for the completion of my thesis.

I express my warmest thanks to Docent Robert Paul, Cert. Transl. for his expert reversion of the English language. I appreciate his valuable comments which improved both the language and contents of thesis. I am happy to know him and I promise in the future to learn word processing.

I own my sincere thanks to Marjut Kauppila, M.D. PhD for excellent collaboration. We have shared the same office at the department and this set the stage for many delightful discussions. She has always been ready to help me, as a true colleague and friend.

I own my special thanks to Hanna Ollikainen, M.D. for support and friendship. It has been a pleasure to associate with her and to travel abroad in her company. I am grateful and thank humbly my dear friend Helena Järviö for her constant support.

I am very grateful to all my hematologist colleagues and friends: Marko Vesanen, M.D., Sanna Asplund, M.D., Urpu Salmenniemi M.D., PhD and Jussi Heiro, M.D. for creating such a pleasant, good-humored and intellectually stimulating atmosphere in which to work.

I thank the skilled and energetic personnel of the Department of Hematology (015). Without them this study would not have been possible. All those nice and enjoyable moments we have shared made living and working less of a burden than they otherwise would have been.

I express my thanks to all senior and junior colleagues of the Department of Medicine for professional collaboration through all these years.

I am deeply indebted to all patients who participated in this study. They are the source and the goal of all this work and they are the ones for whom I have carried on. I salute and thank each one of you.

I thank all my friends for just being there. Friends are for support and encouragement and that is what I have received from you during the years of this endeavor.

Finally, my thanks to those I love the most. I warmly thank my parents Raili and Teuvo Putkonen for their constant love and support. I am grateful to my brother Jyrki and his children Janika and Miro for many delightful moments together. Best and last - my warmest thanks go to my family. I thank Harri, my husband for his constant support and help in our everyday family routines. I am deeply grateful to our dear children, Tuukka and Joona. Thank you for all that love, joy and happiness you have brought Harri and myself!

This work was supported by the Turku University Hospital Research Fund, the Turku University Foundation and the Finnish Society of Hematology.

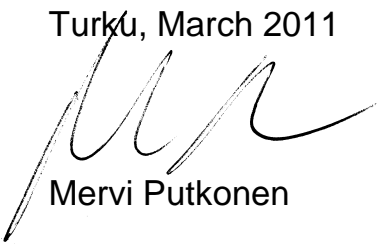




\section{REFERENCES}

Abe M, Hiura K, Wilde J, Moriyama K, Hashimoto T, Ozaki S, Wakatsuki S, Kosaka M, Kido S, Inoue D, Matsumoto T. Role for macrophage inflammatory protein (MIP)-1 $\alpha$ and MIP-1ß in the development of osteolytic lesions in multiple myeloma. Blood 2002; 100: 2195-2202.

Aiuti A, Webb IJ, Bleul C, Springer T, Gutierrez-Ramos JC. The chemokine SDF-1 is a chemoattractant for human CD34+ hematopoietic progenitor cells and provides a new mechanism to explain the mobilization of CD34+ progenitors to peripheral blood. J Exp Med 1997; 185: 111-120.

Alexanian R, Bonnet J, Gehan E, Haut A, Hewlett J, Lane M, Monto R, Wilson H. Combination chemotherapy for multiple myeloma. Cancer 1972; 30: 382-389.

Alexanian R, Weber D, Giralt S, Dimopoulos M, Delasalle K, Smith T, Champlin R. Impact of complete remission with intensive therapy in patients with responsive multiple myeloma. Bone Marrow Transplant $2001 ; 27: 1037-1043$.

Alya E, Weller E, Schlossman R, Canning C, Mauch P, Ng A, Fisher D, Gribben J, Freeman A, Parikh B, Richardson P, Soiffer R, Ritz J, Anderson KC. Outcome after autologous and allogeneic stem cell transplantation for patients with multiple myeloma: impact of graft-versus-myeloma effect. Bone Marrow Transplant 2003; 32: 1145-1151.

Alegre A, Tomas JF, Martinez-Chamorro C, Gil-Fermandez JJ, Fernandez-Villalta MJ, Arranz R, Diaz MA, Granda A, Bernardo MR, Escudero A, Lopez-Lorenzo JL, Fernandez-Ranafa JM. Comparison of peripheral blood progenitor cell mobilization in patients with multiple myeloma: high-dose cyclophosphamide plus GM-CSF vs G-CSF alone. Bone Marrow Transplant 1997; 20: 211-217.

Atta EH, de Azevedo AM, Maiolino A, Coelho CJ, Sarcinelli SM, de Alvarenga MC, Marra VL. High CD8+ lymphocyte dose in the autograft predict early absolute lymphocyte recovery after peripheral hematopoietic stem cell transplantation. Am J Hematol 2009; 84: 21-28.

Attal M, Huguet F, Schlaifer D, Payen C, Laroche M, Fournie B, Mazieres B, Pris J, Laurent G. Intensive combined therapy for previously untreated aggressive myeloma. Blood 1992; 79: 1130-1136.

Attal M, Harousseau JL, Stoppa AM, Sotto JJ, Fuzibet JG, Rossi JF, Casassus P, Maisonneuve H, Facon T, Ifrah N, Payen $\mathrm{C}$, Bataille R. A prospective randomized trial of autologous bone marrow transplantation and chemotherapy in multiple myeloma. Intergroupe Francais du Myelome. N Engl J Med 1996; 335:91-99.

Attal M, Harousseau JL, Facon T, Guilhot F, Doyen C, Fuzibet JG, Monconduit M, Hulin C, Caillot D, Bouabdallah R, Voillat L, Sotto JJ, Grosbois B, Bataille R. Single versus double autologous stem cell transplantation for multiple myeloma. N Engl J Med 2003; 349: 2495-2502.

Attal M, Harousseau JL, Leyvraz S, Doyen C, Hulin C, Benboubker L, Yakoub-Agha I, Bourhis JH, Garderet L, Pegourie B, Dumontet C, Renaud M, Voillat L, Berthou C, Marit G, Monconduit M, Caillot D, Grobois B, Avet-Loiseau H, Moreau P, Facon T, for the Inter-Groupe Francophone du Myélome (IFM). Maintenance therapy with thalidomide improves survival in patients with multiple myeloma. Blood 2006; 108: 3289-3294.

Attal M, Harousseau JL. Role of autologous stem-cell transplantation in multiple myeloma. Best Practice \& Research Clinical Haematology 2007; 20:747-759.

Attal M, Moreau P, Herve A-L, Harousseau JL. Stem Cell Transplantation in Multiple Myeloma. Am Society of Hematology, ASH Education Book 2007; 311-331.

Avet-Loiseau H, Attal M, Moreau P, Charbonnel C, Garban F, Hulin C, Leyvraz S, Michallet M, Yakoub-Agha I, Garderet L, Marit G, Michaux L, Voillat L, Renaud M, Grosbois B, Guillerm G, Benboubker L, Monconduit M, Thieblemont C, Casassus P, Caillot D, Stoppa AM, Sotto JJ, Wetterwald M, Dumontet C, Fuzibet JG, Azais I, Dorvaux V, Zandecki M, Bataille R, Minvielle S, Harousseau JL, Facon T, Mathiot C. Genetic abnormalities and survival in multiple myeloma: the experience of the Intergroupe Francophone du Myelome. Blood 2007; 109: 3489-3495.

Bacher U, Zander AR, Haferlach T, Schnittger S, Fehse B, Kröger N. Minimal residual disease diagnostics in myeloid malignancies in the post transplant period (review). Bone Marrow Transplantat 2008; 42:145-157. 
Bakkus MH, Van Riet I, De Greef C, Van Camp B, Thielemans K. The clonogenic precursor cell in multiple myeloma. Leuk Lymphoma 1995; 18:221-9.

Bakkus MHC, Bouko Y, Samson D, Apperley JF, Thielemans K, Van Camp B, Benner A, Goldschmidt H, Moos M, Cremer FW. Post-transplantation tumour load in bone marrow, as assessed by quantitative ASO$\mathrm{PCR}$, is a prognostic parameter in multiple myeloma. $\mathrm{Br} J$ Haematol 2004; 126:665-67.

Balakumaran A, Robey PG, Fedarko N, Langren O. Bone marrow microenviroment in myelomagenesis: Its potential role in early diagnosis. Review. Expert Rev Molecular Diagnosis 2010; 10: 465-480.

Barlogie B, Alexanian R, Dicke KA, Zagars G, Spitzer G, Jagannath S, Horwitz L. High-dose chemoradiotherapy and autologous bone marrow transplantation for resistant myeloma. Blood 1987; 70: 869-872.

Barlogie B. Hematopoietic stem cell transplant for multiple myeloma (MM). Leukemia 1993; 7: 1095.

Barlogie B. Advances in therapy of multiple myeloma: lessons from acute leukemia. Clin Cancer Resp 1997; 3: 2605-2613.

Barlogie B, Jagannath S, Desikan KR, Mattox S, Vesole D, Siegel D, Tricot G, Munshi N, Fassas A, Singhal S, Mehta J, Anaissie E, Dhodapker D, Nauche S, Cromer J, Sawyer J, Epstein J, Spoon D, Ayers D, Cheson B, Crowley J. Total therapy with tandem transplant for newly diagnosed multiple myeloma. Blood 1999; 93:55-65.

Barlogie B, Desikan R, Eddlemon P, Spencer T, Zeldis J, Munshi N, Badros A, Zangari M, Anaissie E, Epstein J, Shaughnessy J, Ayers D, Spoon D, Tricot G. Extended survival in advanced and refractory multiple myeloma after single-agent thalidomide: identification of prognosis factors in a phase 2 study of 169 patients. Blood 2001; 98: 492-494.

Barlogie B, Kyle RA, Anderson KC, Greipp PR, Lazarus HM, Hurd DD, McCoy J, Moore DF Jr, Dakhil SR, Larier KS, Chapman RA, Cromer JN, Salmon SE, Durie B, Crowley JC. Standard chemotherapy compared with high-dose chemoradiotherapy for multiple myeloma: final results of the phase III US Intergroup trial S4321. J Clin Oncol 2006a; 24:929-936.

Barlogie B, Tricot G, Anaissie E, Shaughnessy J, Rasmussen E, Van Rhee F, Fassas A, Zangari M, Hollmig K, Pineda-Roman M, Lee C, Talamo G, Thertulien R, Kiwan S, Fox M, Crowley J. Thalidomide and hematopoietic stem cell transplantation for multiple myeloma. N Engl Med 2006b; 354: 1021-1030.

Barlogie B, Tricot G, Rasmussen E, Anaisse E, van Rhee F, Zankari M, Fassas A, Hollmig K, Pineda-Roman M, Shaughnessy J, Epstein J, Crowley J. Total therapy 2 without thalidomide in comparison with total therapy1: role of intensified induction and posttransplantation consolidation therapies. Blood 2006c; 107: 2633-2638.

Barlogie B, Anaissie E, van Rhee F, Pineda-Roman M, Zangari M, Shaughnessy J, Epstein J, Crowley J. The Arkansas approach to therapy of patients with multiple myeloma. Best Pract \& Res Clin Haematol 2007; 20:761-781.

Barlogie B, Anaissie E, Haessler J, van Rhee F, Pineda-Roman M, Hollmig K, Alsayed Y, Epstein J, Shaughnessy JD Jr, Crowley J. Complete remission sustained 3 years from treatment initiation is a powerful surrogate for extended survival in multiple myeloma. Cancer 2008; 113:355-9.

Bargetzi MJ, Passweg J, Baertschi E, Schoenenberger A, Gwerder C, Tichelli A, Burger J, Mingrone W, Herrmann R, Gratwohl A, Wernli M. Mobilization of peripheral blood progenitor cells with vinorelbine and granulocyte colony-stimulating factor in multiple myeloma patients is reliable and cost effective. Bone Marrow Transplant 2003; 31: 99-103.

Bataille R, Boccadoro M, Klein B, Durie B, Pileri A. C-reactive protein and beta-2 microglobulin produce a simple and powerful myeloma staging system. Blood 1992; 80: 733-737.

Bataille R, Barlogie B, Lu ZY, Rossi JF, Lavabre-Bertrand T, Beck T, Wijdenes J, Brochier J, Klein B. Biologic effects of anti-interleukin-6 murine monoclonal antibody in advanced multiple myeloma. Blood 1995; 86: 685-691.

Bataille R, Jégo G, Robillard N, Barillé-Nion S, Harousseau JL, Moreau P, Amiot M, Pellat-Deceunynck C. The phenotype of normal, reactive and malignant plasma cells. Identification of "many and multiple myelomas" and of new targets for myeloma therapy. Haematologica 2006; 91: 1234-1240. 
Bensinger WI, Longin K, Appelbaum F, Rowley S, Weaver C, Lilleby K, Gooley T, Lynch M, Higano T, Klarnet J, Chauncey T, Storb R, Buckner CD. Peripheral blood stem cells (PBSCs) collected after recombinant granulocyte colony-stimulating factor (rhG-CSF): an analysis of factors correlating with the tempo of engraftment after transplantation. Br J Haematol 1994; 87:825-831.

Bensinger W, Appelbaum F, Rowley S, Storb R, Sanders JE, Lilleby K, Gooley T, Demirer T, Schiffman K, Weaver C, Clift RA, Charncey T, Klarnet J, Montgomery P, Peterdorfs S, Weider PI, Witherspoon KP, Buckner CD. Factors that influence collection and engraftment of autologous peripheral-blood stem cells. $J$ Clin Oncol 1995; 13:2547-2555.

Bensinger WI. The current status of hematopoietic stem cell transplantation for multiple myeloma. Clin Adv Hematol Oncol 2004; 2:46-52.

Bensinger WI. Is there still a role for allogeneic stem-cell transplantation in multiple myeloma? Best Pract \& Res Clin Haematol 2007; 20: 783-795.

Bensinger WI. Stem cell transplantation for multiple myeloma in the era of novel drugs. J Clin Oncol 2008; 26:480-492.

Berenson JR, Lichtenstein A, Porter L, Dimopolous MA, Bordoni R, George S, Lipton A, Keller A, Ballester O, Kovacs M, Blacklock H, Bell R, Simeone JF, Reitsma DJ, Heffernan M, Seaman J, Knight RD. Long-term pamidronate treatment of advanced multiple myeloma reduces skeletal events. Myeloma Aredia Study Group. J Clin Oncol 1998; 16: 593-602.

Berenson JR, Crowly JJ, Grogan TM, Zangmeister J, Briggs AD, Mills GM, Barlogie B, Salmon SE. Maintenance therapy with alternate-day prednisone improves survival in multiple myeloma patients. Blood 2002; 99: 3163-3168

Bergsagel D, Sprague CC, Austin C, Criffith M. Evaluation of new chemotherapy agents in the treatment of multiple myeloma. IV. L-phenylanine mustard (NSC-8806). Cancer Chemother Reports 1962; $21: 87$.

Bergsagel PL, Kuehln WM, Zhan F, Sawyer J, Barlogie B, Shaughnessy J Jr. Cyclin D dysregulation: an early and unifying pathogenic event in multiple myeloma. Blood 2005; 106: 296-303.

Bergsagel PL. A kinder, gentler way: control of the proliferative tumor compartment, not cosmetic complete response, should be the goal of myeloma therapy. Leukemia 2008; 22: 673-675.

Beveridge RA, Rifkin RM, Moleski RJ, Milkovich G, Reitan JF, Paivanas TA, Jacobs RJ. Impact of longacting growth factors on practice dynamics and patient satisfaction. Pharmacotherapy 2003; 23: 101S$109 \mathrm{~S}$.

Beyer J, Schella N, Zingsem J, Strohscheer I, Schwaner I, Oettle H, Serke S, Huhn D, Sieger W. Hematopoietic rescue after high-dose chemotherapy using autologous peripheral-blood progenitor cells or bone marrow: a randomized comparison. J Clin Oncol 1995; 13: 1328-1335.

Björkstrand B, Ljungman P, Brandt L, Gahrton G, Bird JM, Samson D, Alegre A, Auzanneau G, Blade J, Brunet S, Carlson K, Cavo M, Ferrant A, Gravett P, De Laurenzi A, Prentice HG, Proctor S, Remes K, Troussard X, Verdonk LF, Williams C. Autologous stem cell transplantation in multiple myeloma: results of the European Group for Bone Marrow Transplantation. Stem Cells 1995; 13: 140-146.

Björkstrand BB, Ljungman P, Svensson H, Hermans J, Alegre A, Apperley J, Blade J, Carlson K, Cavo M, Ferrant A, Goldstone AH, de Laurenzi A, Majolino I, Marcus R, Prentice HG, Remes K, Samson D, Sureda A, Verdonck LF, Volin L, Gahrton G. Allogeneic bone marrow transplantation versus autologous stem cell transplantation in multiple myeloma: a retrospective case-matched study from the Europen Group for Blood and Marrow Transplantatation. Blood 1996; 88: 4711-4718.

Björkstrand B. European Group for Blood and Marrow Transplantation Registry studies in multiple myeloma. Semin Hematol 38: 219-225, 2001.

Bladé J, Samson D, Reece D, Apperley J, Björkstrand B, Gahrton G, Gertz M, Giralt S, Jagannath S, Vesole D. Criteria for evaluating disease response and progression in patients with multiple myeloma treated by high-dose therapy and haematopoietic stem cell transplantation. Myeloma subcommittee of the EBMT European Group for Blood and Marrow Transplantation. Brit J Haematol 1998; 102: 1115-1123.

Bladé J, Rosinol L, Sureda A, Ribera JM, Diaz-Mediaville J, Garcia-Larana J, Mateos MV, Palomera L, Fernández-Calvo J, Martí JM, Giraldo P, Carbonell F, Callís M, Trujillo J, Gardella S, Moro MJ, Barez A, Soler A, Font L, Fontanillas M, San Miguel J, for Programa para el Estudio de la Terapéutica en 
Hemopatía Maligna (PETHEMA). High-dose therapy intensification compared with continued standard chemotherapy in multiple myeloma patients responding to the initial chemotherapy: long-term results from a prospective randomized trial from the Spanish cooperative group PETHEMA. Blood 2005; 106: 37553759 .

Blade J, Cibeira MT, Rosinol L. Novel drugs for the treatment of multiple myeloma. Haematologica 2010; 95: 702-704.

Boeve S, Strupeck J, Creech S, Stiff PJ. Analysis of remobilization success in patients undergoing autologous stem cell transplants who fail an initial mobilization: risk factors, cytokine use and costs. Bone Marrow Transplant 2004; 33: 997-1003.

Boiron JM, Marit G, Fabéres C, Cony-Makhoul P, Foures C, Ferrer AM, Cristol G, Sarrat A, Girault D, Reiffers J. Collection of peripheral blood stem cells in multiple myeloma following single high-dose cyclophosphamide with and without recombinant human granulocyte-macrophage colony-stimulating factor (rhGM-CSF). Bone Marrow Transplant 1993; 12:49-55.

Brenner H, Gondos A, Pulte D. Recent major improvement in long-term survival of younger patients with multiple myeloma. Blood 2008; 111: 2521-2526.

Bruce N, McCloskey EV, Kanis JA, Guest JF. Economic impact of using clodronate in management of patients with multiple myeloma. Br J Haematol 1999; 104: 358-364.

Bruno B, Rotta M, Patriarca F, Mordini N, Allione B, Carnevale-Schianca F, Giaccone L, Sorasio R, Omedè P, Baldi I, Bringhen S, Massaia M, Aglietta M, Levis A, Gallamini A, Fanin R, Palumbo A, Storb R, Ciccone $\mathrm{G}$, Boccadoro M. A comparison of allografting with autograft for newly diagnosed myeloma. N Engl J Med 2007; 356: 1110-1120.

Bruns I, Steidl U, Kronenwett R, Fenk R, Graef T, Rohr UP, Neumann F, Fischer J, Scheid C, Hubel K, Haas $\mathrm{R}$, Kobbe $\mathrm{G}$. A single dose of 6 or $12 \mathrm{mg}$ of pegfilgrastim for peripheral blood progenitor cell mobilization results in similar yields of CD34+ progenitors in patients with multiple myeloma. Transfusion 2006; 46: 180-185

Calandra G, McCarty J, McGuirk J, Tricot G, Crocker SA, Badel K, Grove B, Dye A, Bridger G. AMD3100 plus G-CSF can successfully mobilize CD34+ cells from non-Hodgkin`s lymphoma, Hodgkin`s disease and multiple myeloma patients previously failing mobilization with chemotherapy and/or cytokine treatment: compassionate use data. Bone Marrow Transplant 2008; 41: 331-338.

Callander NS, Roodman CD. Myeloma bone disease. Semin Hamatol 2001; 38: 276-285.

Cavo M, Terragna C, Martinelli G, Ronconi S, Zamagni E, Tosi P, Lemoli RM, Benni M, Pagliani G, Bandini G, Tura S. Molecular monitoring of minimal residual disease in patients in long-term complete remission after allogeneic stem cell transplantation for multiple myeloma. Blood 2000; 96: 355-357.

Cavo M, Zamagni E, Tosi P, Tacchetti P, Cellini C, Cangini D, de Vivo A, Testoni N, Nicci C, Terragna C, Grafone T, Perrone G, Ceccolini M, Tura S, Baccarani M, for the writing committee of the Bologna 2002 study. Superiority of thalidomide and dexamethasone over vincristine-doxorubisine-dexamethasone as primary therapy in preparation for autologous transplantation for multiple myeloma. Blood 2005; 106: 3539.

Cavo M, Tosi P, Zamagni E, Cellini C, Tacchetti P, Patriarca F, Di Raimondo F, Volpe E, Ronconi S, Cangini D, Narni F, Carubelli A, Masini L, Catalano L, Fiacchini M, de Vivo A, Gozzetti A, Lazzaro A, Tura S, Baccarani M. Prospective, randomized study of single compared with double autologous stem cell transplantation for multiple myeloma. Bologna 96 clinical study. J Clin Oncol 2007; 25: 2434-2441.

Child JA, Morgan GJ, Davies FE, Owen RG, Bell SE, Hawkins K, Brown J, Drayson MT, Selby PJ. Highdose chemotherapy with hematopoietic stem-cell rescue for multiple myeloma. N Engl J Med 2003; 348: 1875-1883.

Clark RE, Brammer CG. Previous treatment predicts the efficiency of blood progenitor cell mobilization; validation of a chemotherapy scoring system. Bone Marrow Transplant 1998; 22: 859-863.

Corradini P, Voena C, Tarella C, Astolfi M, Ladetto M, Palumbo A, Van Lint MT, Bacigalupo A, Santoro A, Musso M, Majolino I, Boccadoro M, Pileri A. Molecular and clinical remissions in multiple myeloma: role of autologous and allogeneic transplantation of hematopoietic cells. J Clin Oncol 1999; 17:208-215. 
Corradini P, Tarella C, Olivieri A, Gianni AM, Voena C, Zallio F, Ladetto M, Falda M, Lucesole M, Dodero A, Ciceri F, Benedetti F, Rambaldi A, Sajeva MR, Tresoldi M, Pileri A, Bordignon C, Bregni M. Reducedintensity conditioning followed by allografting of hematopoietic cells can produce clinical and molecular remissions in patients with poor-risk hematologic malignancies. Blood 2002; 99: 75-82.

Corradini P, Cavo M, Lokhorst H, Martinelli G, Terragna C, Majolino I, Valagussa P, Boccadoro M, Samson D, Bacigalupo A, Russell N, Montefusco V, Voena C, Gahrton G; Chronic Leukemia Working Party of the European Group for Blood and Marrow Transplantation (EBMT). Molecular remission after myeloablative allogeneic stem cell transplantation predicts a better relapse-free survival in patients with multiple myeloma. Blood 2003; 102:1927-1929.

Corso A, Caberlon S, Pagnucco G, Klersky C, Zappasodi P, Alessandrino EP, Vanelli L, Mangiacavalli S, Lazzarino M, Bernasconi C. Blood stem cell collections in multiple myeloma: definition of a scoring system. Bone Marrow Transplant 2000; 26: 283-286.

Crawley C, Lacobelli S, Björkstrand B, Apperley JF, Niederwieser D, Gahrton G. Reduced-intensity conditioning for myeloma: lower nonrelapse mortality but higher relapse rates compared with myeloablative conditioning. Blood 2007; 109: 3588-3594.

Cremer FW, Ehrbrecht E, Kiel K, Benner A, Hegenbart U, Ho AD, Goldschmidt H, Moos M. Evaluation of the kinetics of the bone marrow tumor load in the course of sequential high-dose therapy assessed by quantitative PCR as a predictive parameter in patients with multiple myeloma. Bone Marrow Transplant 2000; 26: 851-856.

Cunningham D, Paz-Ares L, Milan S, Powles R, Nicolson M, Hickish T, Selby P, Treleavan J, Viner C, Malpas J. High-dose melphalan and autologous bone marrow transplantation as consolidation in previously untreated myeloma. J Clin Oncol 1994; 12:759-763.

Cunningham D, Powles R, Malpas J, Raje N, Milan S, Viner C, Montes A, Hickish T, Nicolson M, Johnson P, Treleaven J, Raymond J, Gore M. A randomized trial of maintenance interferon following high-dose chemotherapy in multiple myeloma. Br J Haematol 1998; 102: 495-502.

Cupta S, Zhou P, Hassoun H, Kewalramani T, Reich L, Costelo S. Hematopoietic stem cell mobilization with intravenous melphalan and G-CSF in patients with chemoresponsive multiple myeloma: report of a phase II trial. Bone Marrow Transplant 2005; 35: 441-447.

Curran MP, Goa KL. Pegfilgrastim. Drugs 2002; 62: 1207-1213.

D’Amato RJ, Loughnan MS, Flynn E, Folkman J. Thalidomide is an inhibitor of angiogenesis. Proc Natl Acad Sci USA 1994; $91: 4082-4085$.

Davies FE, Forsyth PD, Rawstron AC, Owen RG, Pratt G, Evans PAS, Richards SJ, Drayson M, Smith GM, Selby PJ, Child JA, Morgan GJ. The impact of attaining a minimal disease state after high-dose melphalan and autologous transplantation for multiple myeloma. Br J Haematol 2001; 112: 814-819.

Debes-Marun CS, Dewald GW, Bryant S, Picken E, Santana-Davila R, Gonzalez-Paz N, Winkler JM, Kyle RA, Gertz MA, Witzig TE, Dispenzieri A, Lacy MQ, Rajkumar SV, Lust JA, Greipp PR, Fonseca F. Chromosome abnormalities clustering and its implications for pathogenesis and prognosis in myeloma. Leukemia 2003; 17: 427-436.

Demirer T, Buckner CD, Gooley T, Appelbaum FR, Rowley S, Chauncey T, Lilleby K, Storb R, Bensinger WI. Factors influencing collection of peripheral blood stem cells in patients with multiple myeloma. Bone Marrow Transplant 1996; 17: 937-941.

Desikan KR, Tricot G, Dhodapkar M, Fassas A, Siegel D, Vesole DH, Jagannath S, Singhal S, Mehta J, Spoon D, Anaissie E, Barlogie B, Munshi N. Melphalan plus total body irraditation (MEL-TBI) or cyclophosphamide (MEL-CY) as a conditioning regimen with second autotransplant in responding patients with myeloma is inferior compared to historical controls receiving tandem transplants with melphalan alone. Bone Marrow Transplant 2000; 25: 483-487.

Desikan KR, Tricot G, Munshi NC, Annaissie E, Spoon D, Fassas A, Toor A, Zangari M, Badros A, Morris C, Vesole DH, Siegel D, Jagannath S, Barlogie B. Preceding chemotherapy, tumour load and age influence engraftment in multiple myeloma patients mobilized with granulocyte colony-stimulating factor alone. Brit $\mathrm{J}$ Haematol 2001; 112: 242-247. 
Devine SM, Vij R, Rettig M, Todt I, McGlauchlen K, Fischer N, Devine H, Link DC, Calandra G, Bridger G, Westervelt $\mathrm{P}$, Dispersio JF. Rapid mobilization of functional donor hematopoietic cells without G-CSF using AMD3100, an antagonist of CXCR4/SDF-1 interaction. Blood 2008; 112: 990-998.

Dewald GW, Therneau T, Larson D, Lee YK, Fink S, Smoley S, Paternoster S, Adeyinka A, Ketterling R, Van Dyke DL, Fonseca R, Kyle R. Relationship of patient's survival and chromosome anomalies detected in metaphase and/or interphase cells at diagnosis in myeloma. Blood 2005; 106: 3553-3558.

Dimopoulos M, Terpos E, Comenzo RL, Tosi P, Beksac M, Sezer O, Siegel D, Lokhorst H, Kumar S, Rajkumar SV, Niesvizky R, Moulopoulos LA, Durie BGM. On behalf of the IMWG. International myeloma working group consensus statement and guidelines regarding the current role of imaging techniques in the diagnosis and monitoring of multiple myeloma. Leukemia 2009a; 23: 1545-1556.

Dimopoulos MA, Chen C, Spencer A, Niesvizky R, Attal M, Stadtmauer EA, Petrucci MT, Yu Z, Olesnyckyj M Zeldis JB, Knight RD, Weber DM. Long-term follow-up on overall survival from MM-009 and MM-010 phase III trials of lenalidomide plus dexamethasone in patients with relapsed or refractory multiple myeloma. Leukemia 2009b; 11: 2147-2152.

Dingli D, Pacheco JM, Nowakowski GS, Kumar SK, Dispenzieri A, Hayman SR, Lacy MQ, Gastineau DA, Gertz MA. Relationship between depth of response and outcome in multiple myeloma. JClin Oncol 2007; 25: 4933-4937.

Dingli D, Rajkumar SV. How best to use new therapies in multiple myeloma. Blood Rev 2010; 24: 91-100.

Dispenzieri A, Kyle R, Merlini G, Miguel JS, Ludwig H, Hajek R, Palumbo A, Jagannath S, Blade J, Lonial S, Dimopoulos M, Comenzo R, Einsele H, Barlogie B, Anderson K, Gertz M, Harousseau JL, Attal M, Tosi P, Sonneveld P, Boccadoro M, Morgan G, Richardson P, Sezer O, Mateos MV, Cavo M, Joshua D, Turesson I, Chen W, Schmizu K, Powles R, Rajkumar SV, Durie BGM on behalf of the International Myeloma Workin Group. International Myeloma Working group guidelines for serum-free light chain analysis in multiple myeloma and related disoreders. Leukemia 2010; 23: 215-224.

Drake M, Ranaghan L, Morris TCM, Jordan A, Magill K, Price S. Analysis of the effect of prior chemotherapy on progenitor cell yield: use of a chemotherapy scoring system. Br J Haematol 1997; 98:745-749.

Drayson M, Tang LX, Drew R, Mead GP, Carr-Smith H, Bradwell AR. Serun free light chain measurements for identifying and monitoring patients with nonsecretory multiple myeloma. Blood 2001; 97: 2900-2902.

Dreger P, Kloss M, Petersen B, Haferlach T, Loffler H, Loeffler M, Schmitz N. Autologous progenitor cell transplantation: prior exposure to stem cell-toxic drugs determines yield and engraftment of peripheral blood progenitor cells but not of bone marrow grafts. Blood 1995; 86:3970-3978.

Durie BG, Salmon SE. A clinical staging system for multiple myeloma. Correlations of measured myeloma cell mass with presenting clinical features, response to treatment and survival. Cancer 1975; 36: 842-854.

Durie BG, Harousseau JL, Miguel JS, Bladé J, Barlogie B, Anderson K, Gertz M, Dimopoulos M, Westin J, Sonneveld P, Ludwig H, Gahrton G, Beksac M, Crowley J, Belch A, Boccadaro M, Cavo M, Turesson I, Joshua D, Vesole D, Kyle R, Alexanian R, Tricot G, Attal M, Merlini G, Powles R, Richardson P, Shimizu K, Tosi P, Morgan G, Rajkumar SV; International Myeloma Working Group. International uniform response criteria for multiple myeloma. Leukemia 2006; 20: 1467-1473.

Durie BGM. Role of new treatment approaches in defining treatment goals in multiple myeloma - the ultimate goal is extended survival. Cancer Treat Reviews 2010; 362S: 18-23.

Edelstyn CA, Gillespie PJ, Grebbell FS. The radiological demonstration of osseous metastases. Experimental observations. Clin Radiol 1967; 36: 5-16.

Einsele H, Schäfer HJ, Hebart H, Bader P, Meisner C, Plasswilm L, Liebisch P, Bamberg M, Faul C, Kanz L. Follow-up of patients with progressive multiple myeloma undergoing allogratt after reduced-intensity conditioning. Br J Haematol 2003; 121: 411-418.

Engelhardt M, Winkler J, Waller C, Lange W, Mertelsmann R, Henschler R. Blood progenitor cell (BPC) mobilization studied in multiple myeloma, solid tumor and non-Hodgkin's lymphoma patients after combination chemotherapy and G-CSF. Bone Marrow Transplant 1997; 19:529-537.

Facon T, Mary JY, Hulin C, Benboubker L, Attal M, Pegourie B, Renaud M, Harousseau JL, Guillerm G, Chaleteix C, Dib M, Voillat L, Maisonneuve H, Troncy J, Dorvaux V, Monconduit M, Martin C, Casassus P, Jaubert J, Jardel H, Doyen C, Kolb B, Anglaret B, Grosbois B, Yakoub-Agha I, Mathiot C, Avet-Loiseau H; 
Intergroupe Francophone du Myélome. Melphalan and prednisone plus thalidomide versus melphalan and prednisone or reduced-intensity autologous stem cell transplantation in elderly patients with multiple myeloma (IM 99-06): a randomized trial. Lancet 2007; 370: 1209-1218.

Fenk R, Ak M, Kobbe G, Steidl U, Arnold C, Korthals M, Hünerlitürkoglu A, Rohr UP, Kliszewski S, Bernhardt $A$, Haas R, Kronenwett $R$. Levels of minimal residual disease detected by quantitative molecular monitoring herald relapse in patients with multiple myeloma. Haematologica 2004; 89: 557-566.

Fermand JP, Chevret S, Ravaud P, Divine M, Leblond V, Dreyfus F, Mariette X, Brouet JC. High-dose chemoradiotherapy and autologous blood stem cell transplantation in multiple myeloma: results of a phase II trial involving 63 patients. Blood 1993; 82: 2005-2009.

Fermand JP, Ravaud P, Chevret S, Divine M, Leblond V, Belanger C, Macro M, Pertuiset E, Dreyfus F, Mariette X, Boccacio C, Brouet JC. High-dose therapy and autologous peripheral blood stem cell transplantation in multiple myeloma: up-front or rescue treatment? Results of multicenter sequential randomized clinical trial. Blood 1998; 92: 3131-3136.

Fermand JP, Katsahian S, Divine M, Leblond V, Dreyfus F, Macro M, Arnulf B, Royer B, Mariette X, Pertuiset E, Belanger C, Janvier M, Chevret S, Brovet JC, Ravaud P; Group Myelome-Autogreffe. High-dose therapy and autologous blood stem-cell transplantation compared with conventional treatment in myeloma patients aged 55 to 65 years: long-term results of a randomized controlled trial from the Group MyelomeAutogreffe. J Clin Oncol 2005; 23: 9227-9233.

Flomenberg N, Devine SM, DiPersio JF, Liesveld JL, McCarty JM, Rowley SD, Vesole DH, Badel K, Calandra G. The use of AMD3100 plus G-CSF for autologous hematopoietic progenitor cell mobilization is superior to G-CSF alone. Blood 2005; 106: 1867-1874.

Fonseca R, Blood E, Rue M, Harrington D, Oken MM, Kyle RA, Dewald GW, Van Ness B, Van Wier SA, Henderson KJ, Bailey RJ, Greipp PR. Clinical and biologic implications of recurrent genomic aberrations in myeloma. Blood 2003; 101: 4569-4575.

Fonseca R, Barlogie B, Bataille R, Bastard C, Bergsagel PL, Chesi M, Davies FE, Drach J, Greipp PR, Kirsch IR, Kuehl WM, Hernandez JM, Minvielle S, Pilarski LM, Shaughnessy JD Jr, Stewart AK, AvetLoiseau H. Genetics and cytogenetics of multiple myeloma: a workshop report. Cancer Res 2004; 64: 1546-1558.

Fonseca R, Van Wier SA, Chng WJ, Ketterling R, Lacy MQ, Dispenzieri A, Bergsagel PL, Rajkumar SV, Greipp PR, Litzow MR, Price-Troska T, Henderson KJ, Ahmann GJ, Gertz MA. Prognostic value of chromosome 1q21 gain by fluorescent in situ hybridization and increased CKS I B expression in myeloma. Leukemia 2006; 20: 2034-2040.

Fonseca R, Bergsagel PL, Drach J, Shaughnessy J, Gutierrez N, Stewart AK, Morgan G, Van Ness B, Chesi M, Minvielle S, Neri A, Barlogie B, Kuehl Wm, Liebisch P, Davies F, Chen-Kiang S, Durie BGM, Carrasco R, Sezer O, Reiman T, Pilarski L, Avet-Loiseau H. International Myeloma Working Group molecular classification of multiple myeloma: spotlight review. Leukemia 2009; 23: 2210-2221.

Fruehauf S, Klaus J, Veldwiijk MR, Buss EC, Topaly J, Seeger T, Zeller LWJ, Moehler T, Ho AD, Goldschmidt $\mathrm{H}$. Efficient mobilization of peripheral blood stem cell following CAD chemotherapy and a single dose of pegylated G-CSF in patients with multiple myeloma. Bone Marrow Transplant 2007; 39: $743-750$

Fruehauf S, Ehninger G, Hubel K, Topaly J, Goldschmidt H, Ho AD, Muller S, Moos M, Badel K, Calandra G. Mobilization of peripheral blood stem cells for autologous transplant in non-Hodgkin's lymphoma and multiple myeloma patients by plerixafor and G-CSF and detection of tumor cell mobilization by PCR in multiple myeloma. Bone Marrow Transplant 2009; 45: 269-275.

Fu S, Liesveld J. Mobilization of hematopoietic stem cells. Blood Rev 2000; 14: 205-218.

Gahrton G, Svenson H, Björkstrand B, Apperley J, Carlson K, Cavo M, Ferrant A, Fouillard L, Gratecos N, Gratwohl A, Guilhot F, Lambertenghi Deliliers G, Ljugman P, Masszi T, Milligan DW, Powles RL, Reiffers J, Samson JD, Stoppa AM, Venan JP, Volin L, Wallvik J. Syngeneic transplantation in multiple myeloma - a case-matched comparison with autologous and allogeneic transplantation. European Group for Blood and Marrow Transplantation. Bone Marrow Transplant 1999; 24: 741-745.

Gahrton G, Svensson H, Björkstrand B, Apperley J, Carlson K, Bladé J, Cornelissen J, de Laurenzi A, Facon T, Ljungman P, Michallet M, Niederwieser D, Powles R, Reiffers J, Russell NH, Samson D, Schaefer UW, Schattenberg A, Tura S, Verdonck LF, Vernant JP, Willemze R, Volin L; European Group for Blood and 
Marrow Transplantation. Progress in allogeneic bone marrow and peripheral blood stem cell transplantation for multiple myeloma: a comparison between transplant performed 1983-93 and 1994-8 at European Group for Blood and Marrow Transplantation centres. Br J Haematol 2001; 113: 209-216.

Gandhi Mk, Jestice K, Scott MA, Bloxham D, Bass G, Marcus RE. The minimum CD 34 threshold depends on prior chemotherapy in autologous peripheral blood stem cell recipients. Bone Marrow Transplant 1999; 23: 9-13.

Garban F, Attal M, Michallet M, Hulin C, Bourhis JH, Yakoub-Agha I, Lamy T, Marit G, Maloisel F, Berthou C, Dib M, Caillot D, dePrijck B, Ketterer N, Harousseau JL, Sotto JJ, Moreau P, for the Intergroupe Francophone du Myélome and the Swiss Group for Clinical Cancer Research. Prospective comparison of autologous stem cell transplantation followed by dose-reduced allograft (IFM99-03 trial) with tandem autologous stem cell transplantation (IFM99-04 trial) in high risk de novo multiple myeloma. Blood 2006; 107: 3474-3480.

Gazitt Y, Shaughnessy P, Liu Q. Differential mobilization of CD34+ cells and lymphoma cells in nonHodgkin`s lymphoma patients mobilized with different growth factors. J Hematotherapy \& Stem Cell Reseach 2001; 10: 167-176.

Gerlach LO, Skerj RT, Bridger GJ, Schwartz TW. Molecular interactions of cyclam and bicyclam non-peptide antagonists with the CXCR4 chemokine reseptor. J Biol Chem 2001; 276: 14153-14160.

Gimsing P, Carlson K, Turesson I, Fayers P, Waage A, Vangsted A, Mylin A, Gluud C, Juliusson G, Gregersen H, Hjorth-Hansen H, Nesthus I, Dahl IM, Westin J, Nielsen JL, Knudsen LM, Ahlberg L, Hjorth $\mathrm{M}$, Abildgaard N, Andersen NF, Linder O, Wisløff F. Effect of pamidronate $30 \mathrm{mg}$ versus $90 \mathrm{mg}$ on physical function in patients with newly diagnosed multiple myeloma (Nordic Myeloma Study Group). a double blind randomised controlled trial. Lancet Oncol. 2010; 11:973-82.

Giralt S, Stadtmauer EA, Harousseau JL, Palumbo A, Bensinger W, Comenzo R, Kumar S, Munschi NC, Dispenzieri A, Kyle R, Merlini G, San Miguel J, Ludwig H, Hajek R, Jagannath S, Blade J, Lonial S, Dimopolous MA, Einsele H, Barlogie B, Anderson KC, Gertz M, Attal M, Tosi P, Sonneveld P, Boccadoro M, Morgan G, Sezer O, Mateos MV, Gavo M, Joskua D. Turesson I, Chen W, Shimizu K, Powles R, Richardson PG, Nievizky R, Rajkumar SV, Durie BG on the half of the IMWG. International Myeloma Working Group (IMWG) consensus statement and quidelines regarding current status of stem cell collection and high-dose therapy for multiple myeloma and the role of plerixafor (AMD 3100). Leukemia 2009; 23: 1904-1912.

Giuliani N, Morandi F, Tagliaferri S, Rizzoli V. Targeting pathways mediating bone disease. Curr Pharm Biotechnol 2006; 7:423-429.

Goldschmidt H, Hegenbart U, Haas R, Hunstein W. Mobilization of peripheral blood progenitor cells with high-dose cyclophosphamide $\left(4\right.$ or $7 \mathrm{~g} / \mathrm{m}^{2}$ ) and granulocyte stimulating factor in patients with multiple myeloma. Bone Marrow Transplant 1996; 17:691-697.

Goldschmidt H, Hegenbart U, Wallmeier M, Hohaus S, Haas R. Factors influencing collection of peripheral blood progenitor cells following high-dose cyclophosphamide and granulocyte colony-stimulating factor in patients with multiple myeloma. Br J Haematol 1997; 98: 736-744.

Goldschmidt H. Single vs double high-dose therapy in multiple myeloma: second analysis of the GMMG-HD2 Trial. Haematologica 2005; 90: 38PL 8.02.

Green MD, Koelbl H, Baselga J, Galid A, Guillem V, Gascon P, Siena S, Lalisang RI, Samonigg H, Clemens MR, Zani V, Liang BC, Renwick J, Piccart MJ; International Pegfilgrastim 749 Study Group. A randomized double-blind multicenter phase III study of fixed-dose single-administration pegfilgrastim versus daily filgrastim in patients receiving myelosuppressive chemotherapy. Ann Oncol 2003; 14: 29-35.

Greipp PR. Advances in the diagnosis and management of myeloma. Seminars in Hematology 1992; 29: 2445.

Greipp PR, Lust JA, O’Fallon WM, Katzmann JA, Witzig TE, Kyle RA. Plasma cell labelling index and B2Mmicroglobulin predict survival independent of thymidin-kinase and C-reactive protein in multiple myeloma. Blood 1993; 81: 3382-3387.

Greipp PR, San Miguel J, Fonseca R, Avet-Loiseau H, Jacobson JL, Rasmussen E, Crowley J, Durie BMG. Development of an international prognostic index (IPI) for myeloma: report of the international myeloma working group. Hematol J 2003; 4: s42. 
Gribben JG, Neuberg D, Freedman AS, Gimmi CD., Pesek K W, Barber M, Saporito L, Woo SD, Coral F, Spector N, Rabinowe SN, Grossbard ML, Rutz J, Nadler LM. Detection by polymerasechain reaction of residual cells with the bcl-2 translocation is associated with increased risk of relapse after autologous bone marrow transplantation for B-cell lymphoma. Blood 1993; 81: 3449-3457.

Grinani G, Gobbi PG, Formisano R, Pieresca C, Ucci B, Brugnatelli S, Riccardi A, Ascari E. A prognostic index for multiple myeloma. Br J Cancer 1996; 73: 1101-1107.

Guikema JE, Vellenga E, Veeneman JM, Hovenga S, Bakkus MH, Klip H, Bos NA. Multiple myeloma related cells in patients undergoing autologous peripheral blood stem cell transplantation. $\mathrm{Br} \mathrm{J}$ Haematol1999; 104: 748-745.

Gupta R, Bhaskar A, Kumar L, Sharma A, Jain P. Flow cytometric immunophenotyping and minimal residual disease analysis in multiple myeloma. Am J Clin Pathol 2009, 132: 728-732.

Haas R, Möhle R, Fruhauf S, Goldschmidt H, Witt B, Flentje M, Wannenmacher M, Hunstein W. Patient characteristics associated with successful mobilizing and autografting of peripheral blood progenitor cells in malignant lymphoma. Blood 1994; 83:3787-3794.

Hari P, Pasquini MC, Vesole DH. Cure of multiple myeloma - more hype, less reality. Bone Marrow Transplant 2006; 27: 1-18.

Harousseau JL, Milpied N, Laporte JP, Collombat P, Facon T, Tigaud JD, Casassus P, Guilhot F, Ifrah N, Gandhour C. Double intensive therapy in high-risk multiple myeloma. Blood 1992; 79: 2827-2833.

Harousseau JL, Bataille R, Attal M, Divine M, Marit G, Leblond V, Stoppa AM, Bourhis JH, Caillot D, Boasson M, Abgall JF, Facon T, Linassier C, Cahn JY, Lamy T, Troussard X, Gratecos N, Pignon B, Auzanneau G. Autologous stem cell transplantation after first remission induction treatment in multiple myeloma. A report of the French Registry on Autologous Transplantation in Multiple Myeloma. Stem Cells 1995; 13: 132-139.

Harousseau JL. High-dose therapy in multiple myeloma. Ann Oncol 2002; 13: 49-54.

Harousseau JL. Autologous stem cell transplantation in multiple myeloma: none, one, or two? Curr Hematol Rep 2003; 2:171-172.

Harousseau JL, Attal M, Leleu X, Troncy J, Pegourie B, Stoppa AM, Hulin C, Benboubker L, Fuzibet JG, Renaud M, Moreau P, Avet-Loiseau H. Bortezomib plus dexamathasone as induction treatment prior to autologous stem cell transplantation in patients with newly diagnosed multiple myeloma. Haematologica 2006; 91: 1498-1505.

Harousseau JL, Attal M, Avet-Loiseau H. The role of complete response in multiple myeloma. Blood 2009; $114: 3139-46$

Harousseau JL, Attal M, Avet-Loiseau H, Marit G, Caillot D, Mohty M, Lenain P, Hulin C, Facon T, Casassus $\mathrm{P}$, Michallet M, Maisonneuve H, Benboubker L, Maloisel F, Petillon MO, Webb I, Mathiot C, Moreau P. Bortezomib Plus Dexamethasone Is Superior to Vincristine Plus Doxorubicin Plus Dexamethasone As Induction Treatment Prior to Autologous Stem-Cell Transplantation in Newly Diagnosed Multiple Myeloma: Results of the IFM 2005-01 Phase III Trial. J Clin Oncol 2010; 28: 4621-4629.

Hatse S, Princen K, Bridger G, De Clercq E, Schols D. Chemokine receptor inhibition by AMD3100 is strictly confined to CXCR4. FEBS Lett 2002; 527: 255-262.

Hawley RG, Berger LC. Growth control mechanisms in multiple myeloma. Leuk Lymphoma 1998; 29: 465-75

Heider U, Kaiser M, Müller C, Jakob C, Zavrski I, Schulz CO, Fleissner C, Hecht M, Sezer O. Bortezomib increases osteoblasty activity in myeloma patients irrespective of response to treatment. Eur $\mathrm{J}$ Haematol 2006; 77: 233-238.

Hideshima T, Anderson KC. Molecular mechanisms of novel therapeutic approaches for multiple myeloma. Nat Rev Cancer 2002; 2: 927-937.

Hiwase DK, Hiwase S, Bailey M, Bollard G, Schwarer AP. The role of stem cell mobilization regimen on lymphocyte collection yield in patients with multiple myeloma. Cytotherapy 2008; 10:507-17. 
Hjort M, Hellquist L, Holmberg E, Magnusson B, Rödjer S, Westin J. Initial versus deferred melphalanprednisone therapy for asymptomatic multiple myeloma stage I - a randomized study. Eur $\mathrm{J}$ Haematol 1993; 50: 95-102.

Holmes FA, Jones SE, O`Shaughnessy J, Vukelja S, George T, Savib M, Richards D, Glaspy J, Meza L, Cohen G, Dhami M, Budman DR, Hackett J, Brassard M, Yang BB, Liang BC. Comparable efficacy and safety profiles of once-per-cycle pegfilgratsim and daily injection filgrastim in chemotherapy-induced neutropenia: a multicenter dose-finding study in women with breast cancer. Ann Oncol 2002; 13: $903-909$.

Isidori A, Tani M, Bonifazi F, Zinzani P, Curti A, Motta MR, Rizzi S, Giudice V, Farese O, Rovito M, Alinari L, Conte R, Baccarani M, Lemoli LM. Phase II study of a single pegfilgrastim injection as an adjunct to chemotherapy to mobilize stem cells into the peripheral blood of pretreated lymphoma patients. Haematologica 2005; 90: 225-231.

Itälä M, Huhtinen AR, Juvonen V, Kairisto V, Pelliniemi TT, Penttilä TL, Rauhala A, Tienhaara A, Remes K. Stem cell transplantation in poor-risk chronic lymphocytic leukemia: assessment of post-transplant minimal residual disease using four-color and six-color flow cytometry and allele-specific RQ-PCR. Eur J Haematol 2008; 81: 100-106.

Jacobson JL, Hussein MA, Barlogie B, Durie BG, Crowley JJ. A new staging system for multiple myeloma patients based on the Southwest Oncology Group (SWOG) experience. Br J Haematol 2003; 122: 441450.

Jagannath S, Durie B, Wolf J, Camacho E, Irwin D, Lutzky J, McKinley M, Gabayan E, Mazumder A, Schenkein D, Crowley J. Bortezomib therapy alone and in combination with dexamethasone for previously untreated symptomatic multiple myeloma. Br J Haematol 2005; 129: 776-783.

Jagannath S, Richardson PG, Sonneveld P, Schuster MW, Irwin D, Stadtmauer EA, Facon T, Harousseau $\mathrm{JL}$, Cowan JM, Anderson KC. Bortezomib appears to overcome the poor prognosis conferred by chromosome 13 in phase 2-3 trials. Leukemia 2007; 21: 151-157.

Jakob C, Sterz J, Liebisch P, Mieth M, Rademacher J, Goerke A, Heider U, Fleissner C, Kaiser M, von Metzler I, Müller C, Sezer O. Incorporation of the bone marker carboxy-terminal telopeptide of type-1 colagen improves prognostic information of the International Staging System in newly diagnosed symptomatic multiple myeloma. Leukemia 2008; 22: 1767-1772.

Jantunen E, Putkonen M, Nousiainen T, Pelliniemi TT, Mahlamäki E, Remes K. Low-dose or intermediatedose cyclophosphamide plus granulocyte colony-stimulating factor for progenitor cell mobilization in patients with multiple myeloma. Bone Marrow Transplant 2003; 31:347-351.

Jantunen E, Kvalheim G. Mobilization strategies in hard-to-mobilize patients with lymphoid malignancies. Eur J Haematol 2010; 25: 1600-1609.

Johnsen HE. Report from a Nordic workshop on CD34+ cell analysis: technical recom mendations for progenitor cell enumeration in leukapheresis from multiple myeloma patients. J Hematother 1995; 4:21-28.

Johnson PRE, Fitzsimmons CL, Chang J, Morgenstern GR, Scarffe JH. Infection at the time of peripheral blood stem cell leukapheresis results in reduced granulocyte-macrophage colony forming unit yields. Brit $\mathrm{J}$ Haematol 1995; 89: 689-690.

Kastrinakis NG, Gorgoulis VG, Foukas PG, Dimopolous MA, Kittas C. Molecular aspects of multiple myeloma. Ann Oncol 2000; 11: 1217-1228.

Katzmann JA, Stankowski-Drengler TJ, Kyle RA, Karen SL, Snyder MR, Lust JA, Dispenzieri A. Spesificity of serum and urine protein electrophoresis for the diagnosis of monoclonal gammopathies. Clin Chem 2010; 56: 1899-1900.

Koreth J, Cutler CS, Djulbegovic B, Behl R, Schlossman RL, Munshi NC, Richardson PG, Anderson KC, Soiffer RJ, Alyea EP 3rd. High-dose therapy with single autologous transplantation versus chemotherapy for newly diagnosed multiple myeloma: a systematic review and meta-analyses of randomized controlled trials. Biol Blood Marrow Transplant 2007; 13: 183-196.

Kotasek D, Shepherd KM, Sage RE, Dale BM, Norman JE, Charles P, Gregg A, Pillow A, Bolton A. Factors affecting blood stem cell collections following high-dose cyclophosphamide mobilization in lymphoma, myeloma and solid tumors. Bone Marrow Transplant 1992; 9: 11-17. 
Koumakis G, Vassilomanolakis M, Hatzichristou H, Barbounis V, Filis J, Papanastasiou K, Moraki M, Kritsioti M, Plataniotis G, Stamatelou M, Efremidis AP. Predictive factors affecting mobilization and peripheral blood stem cell (PBSC) collection using single apheresis (SA) for rescuing patients after high-dose chemotherapy (HD.CHE) in various malignancies. Bone Marrow Transplant 1996; 18: 1065-1072.

Kroschinsky F, Hölig K, Platzebecker U, Poppe-Thiede K, Ordemann R, Blechschmidt M, Oelschlaegel U, Schaih M, Hänel M, Bornhauser M, Ehninger G. Efficacy of single-dose pegfilgrastim after chemotherapy is highly effective in enhancing the mobilization of autologous CD34+PBSC in patients with lymphoid malignancies and solid tumors. Blood 2004; 104: 788a (abstract 2922).

Kroschinsky F, Hölig K, Poppe-Thiede K, Zimmer K, Ordemann R, Blechschmidt M, Oelschlaegel U, Bornhauser M, Rall G, Rutt C, Ehninger GEfficacy of single-dose pegfilgrastim after chemotherapy for the mobilization of autologous peripheral blood stem cells in patients with malignant lymphoma or multiple myeloma. Transfusion 2006; 46: 1417-1423.

Kröger N, Schwerdfeger R, Kiehl M, Sayer HG, Renges H, Zabelina T, Fehse B, Tögel B, Wittkowsky G, Kuse R, Zander AR. Autologous stem cell transplantation followed by a dose reduced allograft induces high complete remission rate in multiple myeloma. Blood 2002; 100:755-760.

Kröger N, Zabelina T, Ayuk F, Atanackovic D, Schieder H, Renges H, Zander A. Bortezomib after dosereduced allogeneic stem cell transplantation for multiple myeloma to enhance or maintain remission status. Exp Hematol 2006; 34: 770-775.

Kubista E, Glaspy J, Holmes FA, Green MD, Hackett J, Neumann T; Pegfilgrastim Study Group. Bone pain associated with once-per-cycle pegfilgrastim is similar to daily filgrastim in patients with breast cancer. Clin Breast Cancer 2003; 3: 391-398.

Kuehl WM, Bergsagel PL. Multiple myeloma: evolving genetic events and host interactions. Nat Rev Cancer 2002; 2: 175-187.

Kuittinen T, Nousiainen T, Halonen P. Mahlamäki E, Jantunen E. Prediction of mobilization failure in patients with non-Hodgkin`s lymphoma. Bone Marrow Transplant 2004; 33: 907-912.

Kumar S, Lacey MQ, Dispenzieri A, Rajkumar SV, Fonseca R, Greyer S, Allmer C, Witzig TE, Lust JA, Greipp PR, Kyle RA, Litzow MR, Gertz MA . Single agent dexamethasone for pre-stem cell transplant induction therapy for multiple myeloma. Bone Marrow Transplant 2004; 34:485-490.

Kumar S, Dispenzieri A, Lacy MQ, Hayman SR, Fuadi SK, Gastine DA, Litzow MR, Fonseca R, Roy V, Rajkumar SV, Gertz MA. Impact of lenalidomide therapy on stem cell mobilization and engraftment postperipheral blood stem cell transplantation in patients with newly diagnosed myeloma. Leukemia 2007; 21: 2035-2042.

Kumar S, Rajkumar V, Dispenzieri A, Lacey MQ, Hayman SR, Buadi FK, Zeldenrust SR, Dingli D, Russell SJ Lust JA, Greipp PR, Kyle RA, Gertz MA. Improved survival in multiple myeloma and the impact of novel therapies. Blood 2008; 111: 2516-2520.

Kyle RA, Gertz MA, Witzig TE, Lust JA, Lacy MQ, Dispenzieri a, Fonseca R, Rajkumar SV, Offord JR, Larson DR, Plevak ME, Therneau TM, Greipp PR. Review of 1027 patients with newly diagnosed multiple myeloma. Mayo Clin Proc 2003a; 78:21-33.

Kyle RA, Therneau TM, Rajkumar SV, Remstein ED, Offord JR, Larson DR, Plevak MF, Melton LJ. Longterm follow-up of IgM monoclonal gammopathy of undetermined significance. Blood 2003b; 102:37593764.

Kyle RA, Rajkumar SV. Drug therapy, multiple myeloma. N Eng J Med 2004; 28: 1860-1873.

Kyle RA, Durie BG, Rajkumar SV, Landgren O, Blade J, Merlini G, Kröger N, Einsele H, Vesole DH, Dimopoulos M, San Miguel J, Avet-Loiseau H, Hajek R, Chen WM, Anderson KC, Ludwig H, Sonneveld P, Pavlovsky S, Palumbo A, Richardson PG, Barlogie B, Greipp P, Vescio R, Turesson I, Westin J, Boccadoro M; International Myeloma Working Group. Monoclonal gammopathy of undetermined significance (MGUS) and smoldering (asymptomatic) multiple myeloma: IMWG consensus perspectives risk factors for progression and guidelines for monitoring and management. Leukemia 2010; 24: 11211127.

Ladetto M, Omedè P, Sametti S, Donovan JW, Astolfi M, Drandi D, Volpato F, Giaccone L, Giaretta F, Palumbo A, Bruno B, Pileri A, Gribben JG, Boccadoro M. Real-time polymerase chain reaction in multiple 
myeloma: quantitative analysis of tumor contamination of stem cell harvests. Exp Hematol 2002; 30:529536.

Lahtinen R, Laakso M, Palva I, Virkkunen P, Elomaa I. Randomised, placebo-controlled multicentre trial of clodronate in multiple myeloma. Finnish Leukemia Group. Lancet 1992; 340: 1049-1052.

Lahuerta JJ, Martinez-Lopez J, de la Serna J, Blade J, Grande C, Alegre A, Vazquez L, Garcia-Larana J, Sureda A, de la Rubia J, Conde E, Martinez R, Perez-Equiza K, Moraleda JM, Leon A, Besalduch J, Cabrera R, Gonzalez-San Miguel JD, Morales A, Garcia-Ruiz JC, Diaz-Mediavilla J, San-Miguel J for the GETH and PETHEMA Groups. Remission status defined by immunofixation vs. electrophoresis after autologous transplantation has a major impact on the outcome of multiple myeloma patients. Brit $\mathrm{J}$ Haematol 2000; 109: 438-446.

Landgren O, Kyle RA, Pfeiffer RM, Katzmann JA, Caporaso NE, Haves RB, Dispenzieri A, Kumar S, Clark RJ, Baris D, Hoover R, Rajkumar SV. Monoclonal gammopathy of undertermined significance (MGUS) consistently precedes multiple myeloma; a prospective study. Blood 2009; 113: 5412-5417.

Lee CK, Badros A, Barlogie B, Morris C, Zangari M, Fassas A, van Rhee F, Cottler-Fox M, Jacobson J, Thertulien R, Muwalla F, Mazher S, Anaissie E, Tricot G. Prognostic factors in allogeneic transplantation for patients with high-risk multiple myeloma after reduced intensity conditioning. Exp Hematol 2003; 31: 73-80.

Lemoli RM, Martinelli G, Zamagni E, Motta MR, Rizzi S, Terragna C, Rondelli R, Ronconi S, Curti A, Bonifazi F, Tura S, Cavo M. Engraftment, clinical and molecular follow-up of patients with multiple myeloma who were reinfused with highly purified CD34+ cells to support single or tandem high-dose chemotherapy. Blood 2000; 95:2234-2239.

Lenhoff S, Hjorth M, Holmberg E, Turesson I, Westin J, Nielsen JL, Wislöff E, Brinch L, Carlsson M, Dahl IM, Gimsing P, Hippe E, Johnsen H, Lamvik J, Löfvenberg E, Nesthus I, Rödjer S. Impact on survival of highdose therapy with autologous stem cell support in patients younger than 60 years with newly diagnosed multiple myeloma: a population-based study. Blood 2000; 95: 7-11.

Levesque J-P, Liu F, Simmons PJ, Betsuyaku T, Senior RM, Pham C, Link DC. Characterization of hematopoietic progenitor mobilization in protease-deficient mice. Blood 2004; 104: 65-72.

Lokhorst HM, Wu K, Verdonck LF, Laterveer LL, van de Donk NW, van Oers MH, Cornelissen JJ, Schattenberg AV. The occurrence of graft-versus-host disease is the major predictive factor for response to donor lymphocyte infusions in multiple myeloma. N Eng J Med 2004; 348: 1875-1883.

Lokhorst HM, Schmidt-Wolf I, Sonneveld P, van der Holt B, Martin H, Barge R, Bertsch U, Schlenzka J, Bos GM, Croockewit S, Zweegman S, Breitkreutz I, Joosten P, Scheid C, van Marwijk-Kooy M, Salwender HJ, van Oers MH, Schaafsma R, Naumann R, Sinnige H, Blau I, Delforge M, de Weerdt O, Wijermans P, Wittebol S, Duersen U, Vellenga E, Goldschmidt H; Dutch-Belgian HOVON; German GMMG. Thalidomide in induction treatment increases the very good partial remission rate before and after high-dose therapy in previously untreated multiple myeloma. Haematologica 2008; 93: 124-127.

Lokhorst H, Einsele H, Vesole D, Bruno B, San Miguel J, Perez-Simon JA, Kröger N, Moreau P, Gahrton G, Gasparetto C, Giralt S, Bensinger W; International Myeloma Working Group. International Myeloma Working Group consensus statement regarding the current status of allogeneic stem-cell transplantation for multiple myeloma. J Clin Oncol 2010; 28: 4521-4530.

Lonial S, Kaufman J, Tighiouart M, Nooka A, Langston AA, Heffner LT, Torre C, McMillian S, Renfroe H, Harvey RD, Lechowicz MJ, Khoury HJ, Flowers CR, Waller EK. A phase III trial combining high-dose melphalan and autologous transplant with bortezomib for multiple myeloma: a dose- and schedule-finding study. Clin Cancer Res 2010: 16: 5079-5086.

Ludwig H,Fritz E, Friedl HP. Epidemiologic and age-dependent data on multiple myeloma in Austria. J Nat Cancer Inst 1982; 68: 729-733.

Ludwig H, Beksac M, Bladé J, Boccadoro M, Cavenagh J, Cavo M, Dimopoulos M, Drach J, Einsele H, Facon T, Goldschmidt H, Harousseau JL, Hess U, Ketterer N, Kropff M, Mendeleeva L, Morgan G, Palumbo A, Plesner T, San Miguel J, Shpilberg O, Sondergeld P, Sonneveld P, Zweegman S. Current multiple myeloma treatment strategies with novel agents: a European perspective. Oncologist 2010a;15:625.

Ludvig H, Bolejack V, Crowley J, Blade J, San Miguel J, Kyle RA, Rajkumar SV, Shimizu K, Turensson I, Westin J, Sonneveld P, Cavo M, Boccadoro M, Palumbo A, Tosi P, Harousseau JL, Attal M, Barlogie B, 
Stewart AK, Durie B. Survival and years of life in different age cohorts of patients with multiple myeloma. J Clin Oncol 2010b; 28: 1599-1605.

Majado MJ, Salgado-Cecilia G, Blanquer M, Funes C, González-García C, Insausti CL, Parrado A, Morales A, Minguela A, Moraleda JM. Cryopreservation impact on blood progenitor cells: influence of diagnoses, mobilization treatments and cell concentration. Transfusion 2010; 28: 1537-1540.

Majolino I, Corradini P, Scime R, Santoro A, Tarella C, Cavallaro AM, Palumbo A, Indovina A, Caracciolo D, Boccadoro M, Marceno R, Pileri A. Allogeneic transplantation of unmanipulated peripheral blood stem cells in patients with multiple myeloma. Bone Marrow Transplant 1998: 22: 449-455

Mandelli F, Avvisati G, Amadori S, Boccadoro M, Gernone A, Lauta VM, Marmont F, Petrucci MT, Tribalto M, Vegna ML, Dammacco F, Pileri A. Maintenance treatment with recombinant alfa-2b in patients with multiple myeloma responding to conventional induction chemotherapy. N Engl J Med 1990; 322: 14301434.

Marit G, Thiessard F, Fabes G, Cony-Makhoul P, Boiron JM, Bernard P, Pigneux A, Puntous M, Agape P, Vezon G, Broustet A, Girault D, Salmi LR, Reiffers J. Factors affecting both peripheral blood progenitor cell mobilization and hematopoietic recovery following autologous blood progenitor cell transplantation in multiple myeloma: a monocentric study. Leukemia 1998; 12: 1447-1456.

Martinelli G, Terragna C, Zamagni E, Ronconi S, Tosi P, Lemoli RM, Bandini G, Testoni N, Amabile M, Ottaviani E, Buonamici S, Soverini S, Montefusco V, de Vivo A, Bonifazi F, Tura S, Cavo M. Polymerase chain reaction-based detection of minimal residual disease in multiple myeloma patients receiving allogeneic stem cell transplantation. Haematologica 2000; 85: 930-934.

Mateos MV, San Miguel JF. Bortezomib in multiple myeloma. Best Pract Res Clin Haematol 2007; 20:701-15.

McElwain TJ, Powles RL. Hihg-dose intravenous melphalan for plasma-cell leukemia and myeloma. Lancet 1983; 2: 822-824.

McKenna RW, Kyle RA, Kuehl WN, Grogan TM, Harris NL, Coupland RW. Plasma cell neoplasms. WHO Classification of Tumours of Haematopoietic and Lymphoid Tissues 2008: 200-209.

Mellqvist U-H, Westin J, Gimsing P, Hjertner O, Lenhoff S, Laane E, Remes K, Steingrimsdottir H, Abildgaard N, Ahlberg L, Carlsson K, Dahl IM, Forsberg K, Gedde-Dahl T, Gregersen H, Gruber A, Guldbrandsen N, Haukås E, Linder O, Nahi H, Nesthus I, Toffner-Clausen N, Silvennoinen R, Andersen NF, Turesson I, Waage A. Improved response rate with bortezomib consolidation after high dose melphalan: First results of a Nordic Myeloma Study Group randomized phase III trial. Blood (ASH Annual Meeting Abstracts) 2009; 114: 530.

Mitsiades CS, McMillin DW, Klippel S, Hideshima T, Chauhan D, Richardson PG, Munshi NC, Andersson KC. The role of the bone marrow microenviroment in the pathophysiology of myeloma and its significance in the development of more effective therapies. Hematol Clin North Am 2007; 21: 1007-1034.

Moog R. Mobilization and harvesting of peripheral blood stem cells. Curr Stem Cell Res Ther 2006; 1:189201.

Moreno C, Villamor N, Colomer D, Esteve J, Martino R, Nomdedeu J. Allogeneic stem-cell transplantation may overcome the adverse prognosis of unmutated VH gene in patients with chronic lymphocytic leukemia. J Clin Oncol 2005; 23: 2433-2438.

Morgan GJ, Davies FE. Evolving treatment strategies for myeloma. Br J Cancer 2005; 92: 217-221.

Morgan GJ, Davies FE, Gregory WM, Cocks K, Bell SE, Szubert AJ, Navarro-Coy N, Drayson MT, Owen RG, Feyler S, Ashcroft AJ, Ross F, Byrne J, Roddie H, Rudin C, Cook G, Jackson GH, Child JA; National Cancer Research Institute Haematological Oncology Clinical Study Group. First-line treatment with zolendronic acid as compared with clodronic acid in multiple myeloma (MRC Myeloma IX): a randomised controlled trial. Lancet 2010: 376: 1989-1999.

Mortuza FY, Papaioannou M, Moreira IM, Coyle LA, Gameiro P, Gandini D, Prentice HG, Goldstone A, Hoffbrand AV, Forono L. Minimal residual disease tests provide an independent predictor of clinical outcome in adult acute lymphoblastic leukemia. J Clin Oncol 2002; 20: 1094-1104.

Myeloma Trialist`s Collaborative Group. Combination chemotherapy versus melphalan plus prednisone as treatment for multiple myeloma: an overview of 6,633 patients from 27 randomized trials. J Clin Oncol 1998; 16:3832-3842. 
Nervi B, Link DC, DiPersio JF. Cytokines and hematopoietic stem cell mobilization. J Cell Biochem 2006; 99:690-705.

Nooka A, Kaufman J, Lonial S. The importance of complete response in outcomes in myeloma. Cancer J 2009; 15:465-72.

Nosari A, Cairoli R, Ciapanna D, Gargantini L, Intropido L, Barate L, Scarpatini B, Santoleri L, Nador G, Pezzetti L, Morra E. Efficacy of single dose pegfilgrastim in enhancing the mobilization of CD34+ peripheral blood stem cells in aggressive lymphoma patients treated with cisplatin-aracytin-containing regimens. Bone Marrow Transplant 2006;38: 413-416.

Oakervee HE, Popat R, Curry N, Smith P, Morris C, Drake M, Agrawal S, Stec J, Schenkein D, Esseltine DL, Cavenagh JD. PAD combination therapy (PS-341/bortezomib, doxorubicin and dexamethasone) for previously untreated patients with multiple myeloma. Br J Haematol 2005; 129: 776-783.

Oivanen T, Kellokumpu-Lehtinen P, Koivisto AM, Koivunen E. Response rate and survival after conventional chemotherapy for multiple myeloma by hospitals with different inclusion rates of patients to the trials. A Finnish Leukemia Group study. Eur J Haematol 1999; 83: 225-230.

Olavarria E, Kanfer E, Szydlo R, Kaeda J, Rezvani K, Cwynarski K, Pocock C, Dazzi F, Craddock D, Apperley JF, Cross NC, Goldman JM. Early detection of BCR-ABL transcripts by quantitative reverse transcriptase-polymerase chain reaction predicts outcome after allogeneic stem cell transplantation for chronic myeloid leukemia. Blood 2001; 97: 1560-1565.

Osman K, Comenzo R, Rajkumar SV. Deep venous thrombosis and thalidomide therapy for multiple myeloma. N Engl J Med 344: 1951-1952, 2001.

Paiva B, Vidriales MB, Cerveró J, Mateo G, Pérez JJ, Montalbán MA, Sureda A, Montejano L, Gutiérrez NC, García de Coca A, de Las Heras N, Mateos MV, López-Berges MC, García-Boyero R, Galende J, Hernández J, Palomera L, Carrera D, Martínez R, de la Rubia J, Martín A, Bladé J, Lahuerta JJ, Orfao A, San Miguel JF; GEM (Grupo Español de MM)/PETHEMA (Programa para el Estudio de la Terapéutica en Hemopatías Malignas) Cooperative Study Groups. Multiparameter flow cytometric remission is the most relevant prognostic factor for multiple myeloma patients who undergo autologous stem cell transplantation. Blood 2008; 112:4017-4023.

Palumbo A, Tricolo S, Argentino C, Bringhen S, Dominietto A, Rus C, Omede P, Tarella C, Pileri A, Boccadoro M. Dose-intensive melphalan (MEL100) with stem cell support is superior to standard treatment in elderly myeloma patients. Blood 1999; 94: 1248-1253.

Palumbo A, Bringhen S, Petrucci MT, Musto P, Rossini F, Nunzi M, Lauta VM, Bergonzi C, Barbui A, Caravita T, Capaldi A, Pregno P, Guglielmelli T, Grasso M, Gallea V, Bertola AM, Cavallo F, Falco P, Rus C, Massaia M, Mandelli F, Carella AM, Pogliani E, Liberati AM, Dammacco F, Ciccone G, Boccadoro M. Intermediate-dose melphalan improves survival of myeloma patients aged 50 to 70 : results of a randomized controlled trial. Blood 2004; 104:3052-3055.

Palumbo A, Bringhen S, Caravita T, Merla E, Capparella V, Callea V, Cangialosi C, Grasso M, Rossini F, Galli M, Catalano L, Zamagni E, Petrucci MT, De Stefano V, Ceccarelli M, Ambrosini MT, Avonto I, Falco P, Ciccone G, Liberati AM, Musto P, Boccadoro M; Italian Multiple Myeloma Network, GIMEMA. Oral melphalan and prednisone chemotherapy plus thalidomide compared with melphalan and prednisone alone in elderly patients with multiple myeloma: randomized controlled trial. Lancet 2006; 367: 825-831.

Peled A, Petit I, Kollet O, Magid M, Ponomaryov T, Byk T, Nagler A, Ben-Hur H, Many A, Shutlz L, Lider O, Alon R, Zipori D, Lapidot T. Dependence of human stem cell engraftment and repopulation of NOD/SCID mice on CXCR4. Science 1999; 283: 845-848.

Perea G, Sureda A, Martino R, Altés A, Martínez C, Cabezudo E, Amill B, Martín-Henao GA, González Y, Muñoz L, Peyret M, Brunet S, Sierra J. Predictive factors for a successful mobilization of peripheral blood CD34+ cells in multiple myeloma. Ann Hematol 2001; 80: 592-597.

Phekoo KJ, Schey SA, Richards MA, Bevan DH, Bell S, Gillett D, Moller H; on behalf of Consultant Haematologists, South Thames Haematology Spesialist Committee. A population study to define the incidence and survival of multiple myeloma in a National Health Service Region in UK. Br J Med 2004; 127: 299-304.

Pineda-Roman M, Bolejack V, Arzoumanian V, Anaissie E, van Rhee F, Zangari M, Walker R, Hollmig K, Shaughnessy JD Jr, Epstein J, Krishna S, Crowley J, Barlogie B. Complete response in myeloma extends 
survival without, but not with history of prior monoclonal gammopathy of undetermined significance or smouldering disease. Br J Haematol 2008; 136: 393-399.

Podar K, Chauhan D, Anderson KC. Bone marrow microenvironment and the identification of new targets for myeloma therapy. Leukemia 2009; 23: 10-24.

Porrata LF, Gertz MA, Geyer SM, Litzow MR, Gastineau DA, Moore SB, Pineda AA, Bundy KL, Padley DJ, Persky D, Lacy MQ, Dispenzieri A, Snow DS, Markovic SN. The dose of infused lymphocytes in the autograft directly correlates with clinical outcome after autologous peripheral blood hematopoietic stem cell transplantation in multiple myeloma. Leukemia 2004; 18:1085-92.

Prince HM, Imrie K, Sutherland DR, Keating A, Meharchand J, Crump RM, Girouard C, Trip K, Stewart AK. Peripheral blood progenitor cell collections in multiple myeloma: predictors and management of inadequate collections. Br J Haematol 1996; 93:142-145.

Raab MS, Podar K, Breitkreutz I, Richardson PG, Anderson KC. Multiple myeloma. Lancet 2009; 374:324-39.

Raje N, Anderson KC. Multiple myeloma. Curr Treat Options 2001; 1: 73-82.

Rajkumar SV, Fonseca R, Lacy MQ. Abnormal cytogenetics predict for poor survival after peripheral stem cell transplantation in relapsed multiple myeloma. Blood 1997; 90: 527a (abstr.)

Rajkumar SV, Greipp PR. Prognostic factors in multiple myeloma. Hematol Oncol Clin North Am 1999; 13: 1295-1314.

Rajkumar SV, Fonseca R, Dispepanzieri A. A phase of thalidomide in the treatment of relapsed multiple myeloma (MM) with laboratory correlative studies. Blood 2000; 96: 168a (abstr).

Rajkumar SV, Dispenzieri A, Fonseca R, Lacy MQ, Geyer S, Lust JA, Kyle RA, Greipp PR, Gertz MA, Witzig TE. Thalidomide for previously untreated indolent or smoldering multiple myeloma. Leukemia 2001; 15: 1274-1276.

Rajkumar SV, Mesa RA, Fonseca R, Schroeder G, Plevak MF, Dispenzieri A, Lacy MQ, Lust JA, Witzig TE, Gertz MA, Kyle RA, Russell SJ, Greipp PR. Bone marrow angiogenesis in 400 patients with monoclonal gammopathy of undertermined significance, multiple myeloma and primary amyloidosis. Clin Cancer Res 2002; 8: 927-937.

Rajkumar SV, Kyle RA. Multiple myeloma: Diagnosis and treatment. Mayo Clin Proc 2005; 80: 1371-1382.

Rajkumar SV, Buadi F. Multiple myeloma: new staging systems for diagnosis, prognosis and response evaluation. Best Pract Res Clin Haematol 2007a; 20:665-80.

Rajkumar SV, Palumbo A. Management of newly diagnosed myeloma. Hematol Oncol Clin North Am 2007b; 21:1141-56.

Rasmussen T, Knudsen LM, Huynh TK, Johnsen HE. Molecular and clinical follow-up after treatment of multiple myeloma. Acta Haematol 2004; 112: 105-110.

Rawstron AC, Owen RG, Davies FE, Johnson RJ, Jones RA, Richards SJ, Evans PA, Child JA, Smith GM, Jack AS, Morgan GJ. Circulating plasma cells in multiple myeloma: characterization and correlation with disease stage. Br J Haematol 1997; 97: 46-55.

Rawstron AC, Orfao A, Beksac M, Bezdickova L, Brooimans RA, Bumbea H, Dalva K, Fuhler G, Gratama J, Hose D, Kovarova L, Lioznov M, Mateo G, Morilla R, Mylin AK, Omedé P, Pellat-Deceunynck C, Perez Andres M, Petrucci M, Ruggeri M, Rymkiewicz G, Schmitz A, Schreder M, Seynaeve C, Spacek M, de Tute RM, Van Valckenborgh E, Weston-Bell N, Owen RG, San Miguel JF, Sonneveld P, Johnsen HE; European Myeloma Network. Report of the European Myeloma Network of multiparametric flow cytometry in multiple myeloma and related disordes. Haematologica 2008; 93: 431-438.

Reiffers J, Marit G, Boiron JM. Autologous blood stem cell transplantation in high-risk multiple myeloma. $\mathrm{Br} \mathrm{J}$ Haematol 1989; 72:296-297.

Remes K, Matinlauri I, Grenman S, Itälä M, Kauppila M, Pelliniemi TT. Daily measurements of blood CD34+ cells after stem cell mobilization predict stem cell yield and posttransplant hematopoietic recovery. J Hematother 1997; 6:13-19. 
Remes K, Itälä M, Kauppila M, Pelliniemi T-T, Rajamäki A. Autologous blood cell transplantation in multiple myeloma: Impact of CD34+ cell selection with long follow-up. J Hematother Stem Cell Res 2003; 12: 6370 .

Riccardi A, Mora O, Tinelli C, Valentini D, Brugnatelli S, Spanedda R, De Paoli A, Barbaro L, Di Stasi M, Giodano M, Delfini C, Nicoletti G, Bergonzi C, Rinaldi E, Piccini L, Ascari E. Long-term survival of stage I multiple myeloma given chemotherapy just after diagnosis or at progression of the disease: a multicentre randomized study. Co-operative Group of Study and Treatment of Multiple Myeloma. Br J Cancer 2000; 82: $1254-1260$

Richardson P, Hideshima T, Anderson K. Thalidomide: emerging role in cancer medicine. Ann Rev Med 2002; 53: 629-657.

Richardson PG, Anderson KC. Bortezomib: a novel therapy approved for multiple myeloma. Clin Adv Hematol Oncol 2003; 1: 596-600.

Richardson P, Blood E, Mitsiades C, Jagannath S, Zeldenrust SR, Alsina M, Schlossman RL, Rajkumar SV, Desikan KR, Hideshima T, Munshi NC, Kelly-Colson K, Doss D, McKenney ML, Gorelik S, Warren D, Freeman A, Rich R, Wu A, Olesnyckyj M, Wride K, Dalton WS, Zeldis J, Knight R, Weller E, Anderson KC. A randomized phase II study of lenalidomide therapy for patients with relapsed or relapsed and refractory multiple myeloma. Blood 2006; 108: 3458-3464.

Richardson PG, Mitsiades C, Schlossman R, Ghobrial I, Hideshima T, Munshi N, Anderson KC. Bortezomib in the front-line treatment of multiple myeloma. Expert Rev Anticancer Ther 2008; 8:1053-72.

Roodman GD. Role of the bone marrow microenviroment in multiple myeloma. J Bone Miner Res 2002; 17: 1921-1925.

Rosen LS. Gordon D, Kaminski M, Howell A, Belch A, Mackey J, Apffelstaedt J, Hussein MA, Coleman RE, Reitsma DJ, Chen BL, Seaman JJ. Long -term efficacy and safety of zolendronic acid compared with pamidronate disodium in the treatment of skeletal complications in patients with advanced multiple myeloma or breast carcinoma; a randomized, double-blind, multicenter, comparative trial. Cancer 2003; 98 . 1735-1744.

Rosinol L, Perez-Simon JA, Sureda A, de la Rubia J, de Arriba F, Lahuerta JJ, González JD, Díaz-Mediavilla J, Hernández B, García-Frade J, Carrera D, León A, Hernández M, Abellán PF, Bergua JM, Miguel JS, Bladé J, for Programa para el Estudio y la Terapéutica de las Hemopatías Malignas y Grupo Español de Mieloma (PETHEMA/GEM). A prospective PETHEMA study of tandem autologous transplantation versus autograft followed by reduced-intensity conditioning allogeneic transplantation in newly diagnosed multiple myeloma. Blood 2009; 112: 3591-3593.

Ross FM, Ibrahim A, Vilain-Holmes A, Winfield MO, Chiecchio L, Protheroe RKM, Strike P, Gunasekera JL, Jones A, Harrison CJ, Morgan GJ, Cross NCP on behalf of the UK Myeloma Forum. Age has a profound effect on the incidence and significance of chromosome abnormalities in myeloma. Leukemia 2005; 19: 1634-1642.

Roux S, Mariette $\mathrm{X}$. The high rate of bone resorption in multiple myeloma is due to RANK (receptor activator of nuclear factor-kappaB) and RANK Ligand expression. Leuk Lymphoma 2004; 45: 1111-1118.

San-Miguel J, Harousseau JL, Joshua D, Anderson KC. Individualizing treatment of patients with myeloma in the era of novel agents. J Clin Oncol 2008; 26:2761-66.

Santamaria C, Chillon MC, FernandezC, Martin-Jimenez P, Balanzategui A, Garcia Sanz R, San Miguel JR, Gonzales MG. Using quantification of the PML-RAR alpha transcript to stratify the risk of relapse in patients with acute promyelocytic leukemia. Haematologica 2007; 92: 315-322.

San-Miguel J, Harousseau JL, Joshua D, Anderson KC. Individualizing treatment of patients with myeloma in the era of novel agents. J Clin Oncol 2008; 26:2761-66.

Schaar CG, Kluin-Nelemans HC, te Marvelde C, le Cessie S, Breed WP, Fibbe WE, van Deijk WA, Fickers NN, Roozendaal KJ, Wijermans PW and on behalf of the Dutch-Belgian Hemato-Oncology Cooperative Group HOVON. Interferon-a maintenance therapy in patients with multiple myeloma. Ann Oncol 2005; 16: 634-639.

Seidl S, Kaufmann H, Drach J. New sights into the pathophysiology of multiple myeloma. Lancet Oncol 2003; 4: 557-564. 
Shah JJ, Orlowski RZ. Proteasome inhibitors in the treatment of multiple myeloma. Leukemia 2009; 23: 1964-1979.

Shaughnessy JD, Zhan F Jr, Burington BE, Huang Y, Colla S, Hanamura I, Stewart JP, Kordsmeier B, Randolph C, Williams DR, Xiao J, Xu H, Epstein J, Anaissie E, Krishna SG, Cottler-Fox M, Hollmig K, Mohiuddin A, Pineda-Roman M, Tricot G, van Rhee F, Sawyer J, Alsayed Y, Walker R, Zangari M, Crowley J, Barlogie B. A validated gene expression model of high-risk multiple myeloma is defined by deregulated expression of genes mapping to chromosome 1. Blood 2007; 109: 2276-2284.

Shustik C, Belch A, Robinson S, Rubin SH, Dolan SP, Kovacs MJ, Grewal KS, Walde D, Barr R, Wilson J, Gill K, Vickars L, Rudinskas L, Sicheri DA, Wilson K, Djurfeldt M, Shepherd LE, Ding K, Meyer RM. Dexamethason maintenance versus observation in patients with previously untreated multiple myeloma: a National Cancer Institute of Canada Clinical Trials Group. J Clin Oncol 2004; 145: 651.

Sienna S, Schiavo R, Pedrazzoli P, Carlo-Stella C. Therapeutic relevance of CD34 cell dose in blood cell transplantation for cancer therapy. J Clin Oncol 2000; 18:1360-1377.

Sienna S, Piccart MJ, Holmes FA, Glaspy J, Hackett J, Renwick JJ. A combined analysis of two pivotal randomized trials of a single dose of pegfilgrastim per chemotherapy cycle and daily filgrastim in patients with stage II-IV breast cancer. Oncol Rep 2003; 10: 715-724.

Silvestris F, Cafforio P, Tucci M, Grinello D, Dammacco F. Upregulation of osteoblast apoptosis by malignant plasma cells: a role in myeloma bone disease. $\mathrm{Br} \mathrm{J}$ Haematol 2003; 122: 39-52.

Silvestris F, Cafforio P, Calvani N, Dammacco F. Impaired osteoblastogenesis in myeloma bone disease: role of upregulated apoptosis by cytokines and malignant plasma cells. $\mathrm{Br} \mathrm{J}$ Haematol 2004; 126: 475-486

Singhal S, Mehta J, Desikan R. Antitumor activity of thalidomide in refractory multiple myeloma. N Engl J Med 1999; 341: 1565-1571.

Singhal S, Powles R, Sirohi B, Treleaven J, Kulkarni S, Mehta J. Response to induction chemotherapy is not essential to obtain survival benefit from high-dose melphalan and autotransplantation in myeloma. Bone Marrow Transplant 2002; 30: 673-679.

Smith A, Wisloff F, Samson D. Guidelines on the diagnosis and management of multiple myeloma $2005 . \mathrm{Br} J$ Haematol 2005; 132:410-45.

Solly S. Remarks on the pathology of mollities ossium; with cases. Med Chir Trans 1844; 27:435-498.

Sonneveld P, van der Holt B, Segeren CM, Vellenga E, Croockewit AJ, Verhoe GE, Cornelissen JJ, Schaafsma MR, van Oers MH, Wijermans PW, Westveer PH, Lokhorst HM; Dutch-Belgian HematoOncology Cooperative Group (HOVON). Intensive versus double intensive therapy in untreated multiple myeloma: update analysis of the randomized phase III HOVON 24 study. Hematol/Hematol J 2005: 90:3740.

Spencer A, Prince HM, Roberts A. Thalidomide and hematopoietic stem cell transplantation for multiple myeloma. Haematologica 2007; $92: 41$ (abstr.).

Steidl U, Fenk R, Bruns I, Neumann F, Kondakci M, Hoyer B, Gräft T, Rohr U-P, Bork S, Kronenwett R, Haas $R$, Kobbe G. Successfull transplantation of peripheral blood stem cells mobilized by chemotherapy and a single dose of pegylated G-CSF in patients with multiple myeloma. Bone Marrow Transplant 2005; 35:3336.

Stewart K, Vescio R, Schiller G, Ballester O, Noga S, Rugo H, Freytes C, Stadtmauer E, Tarantolo S, Sahebi F, Stiff P, Meharchard J, Schlossman R, Brown R, Tully H, Benyunes M, Jacobs C, Berenson R, White M, DiPersio J, Anderson KC, Berenson J. Purging of autologous peripheral-blood stem cells using CD34 selection does not improve overall or progression-free survival after high-dose chemotherapy for multiple myeloma: Results of a multicenter randomized controlled trial. J Clin Oncol 2001; 17: 3771-3779.

Tarella C, Boccadoro M, Omedé P, Bondesan P, Caracciolo D, Frieri R, Bregni M, Siena S, Gianni AM, Pileri A. Role of chemotherapy and GM-CSF on hemopoietic progenitor cell mobilization in multiple meyloma. Bone Marrow Transplant 1993; 11: 271-277.

Terpos E, Palermos J, Tsionos K, Anargyrou K, Viniou N, Papassavas P, Meletis J, Yataganas X. Effect of pamidronate administration on markers of bone turnover and disease activity in multiple myeloma. Eur $\mathrm{J}$ Haematol 2000; 65: 331-336. 
Terpos E, Dimopoulos MA. Myeloma bone disease: pathofysiology and management. Ann Oncol 2005; 16: 1223-1231.

Terpos E, Sezer O, Croucher PI, Garcia-Sanz R, Boccadoro M, San Miguel J, Ashcroft J, Blade J, Cavo M, Delforge M, Dimopolous MA, Facon T, Macro M, Waage A, Sonneveld P. The use of bisphosphonates in multiple myeloma: Recommendations of an expert panel on behalf of the European Myeloma Network. Ann Oncol 2009; 20: 1303-1317.

To LB, Shepperd MK, Haylock D, Dyson PG, Charles P, Thorp DL, Dale BM, Dart GW, Roberts MM, Sage RE. Single high doses of cyclophosphamide enable the collection of high numbers of stem cells from the peripheral blood. Exp Hematol 1990; 18:442-7.

Tricot G, Jagannath S, Vesole D, Nelson J, Tindle S, Miller L, Cheson B, Crowley J, Barlogie B. Peripheral blood stem cell transplants for multiple myeloma: Identification of favorable variables for rapid engraftment in 225 patients. Blood 1995; 85: 588-596.

Tricot G, Vesole DH, Jagannath S, Hilton J, Munski N, Barlogie B. Gratf-versus-myeloma effect: proof of principle. Blood 1996; 87: 1196-1198.

Tricot G, Spencer T, Sawyer J, Spoon D, Desikan R, Fassas A, Badros A, Zangari M, Munshi N, Anaissie E, Toor A, Barlogie B. Predicting long-term ( $>$ or $=5$ years) event-free survival in multiple myeloma patients following planned tandem autotransplants. Br J Haematol 2002; 116: 211-217.

Tricot G. What is the significance of molecular remission in multiple myeloma? Clin Adv Hematol Oncol 2007, 5: 91-95.

Tricot G, Barlogie B, Zangari M, van Rhee F, Hoering A, Szymonifka J, Cottler-Fox M. Mobilization of peripheral blood stem cells in myeloma with either pegfilgrastim or filgrastim following chemotherapy. Haematologica 2008; 93: 1739-1742.

Tseng S, Pak G, Washenik K, Pomeranz MK, Shupack JL. Rediscovering thalidomide: a review of its mechanism of action, side effects and potential uses. J Am Acad Dermatol 1996; 35: 969-967.

Turesson I, Zettervall O, Cuzick J, Waldenstrom JG, Velez R. Comparison of trends in the incidence of multiple myeloma in Malmö, Sweden and other countries, 1950-1979. N Engl J Med 1984; 310: 421-424.

Vacca A, Ribatti D, Roncali L, Ranieri G, Serio G, Silvestris F, Dammacco F. Bone marrow angiogenesis and progression in multiple myeloma. Br J Haematol 1994;87:503-508.

Van de Velde HJ, Liu X, Chen G, Cakana A, Deraeedt W, Bayssas M. Complete remission correlates with long-term survival and progression free survival in high-dose therapy in multiple myeloma. Haematologica 2007; 92: 1399-1406.

Van der Velden, Hochhaus A, Cazzaniga G, Szczepanski T, Gabert J, van Dongen JJ. Detection of minimal residual disease in hematologic malignancies by real-time quantitative PCR: principles, approaches and laboratory aspects. Leukemia 2003; 17: 1013-1034.

Verdonck LF, Lokhorts HM, Dekker AW, Nieuwenhuis HK, Petersen EJ. Graft-versus-myeloma effect in two cases. Lancet 1996; 347: 800-801.

Verhagen O, Willemse M, Breunis W, Wijkhuijs A, Jacobs D, Joosten S, van Wering $E$, van Dongen J, van der Schoot C. Application of germline IGH probes in real-time quantitative PCR for the detection of minimal residual disease in acute lymphoblastic leukemia. Leukemia 2000; 14: 1426-1435.

Vesole DH, Jagannath S, Tricot G, Desikan KR, Siegel D, Barlogie B. Autologous bone marrow and peripheral blood stem cell transplantation in multiple myeloma. Cancer Invest 1996; 14: 378-391.

Voena C, Malnati M, Majolino I, Faga G, Montefusco V, Farina L, Santoro A, Ladetto M, Boccadoro M, Corradini P. Detection of minimal residual disease by real-time PCR can be used as a surrogate marker to evaluate the graft-versus-myeloma effect after allogeneic stem cell transplantation. Bone Marrow Transplantat 2003; 32:791-793.

Waage A, Gimsing P, Fayers P, Abildgaard N, Ahlberg L, Björkstrand B, Carlson K, Dah IM, Forsberg K, Guldbrandsen N, Haukas E, Hjertner O, Hjort M, Karlsson T, Knudsen LM, Nielsen JL, Linder O, Mellqvist U-H, Nesthus I, Roike J, Strandberg M, Sorbo JH, Wisloff F, Juliusson G, Turesson I and for the Nordic Myeloma Study Group. Melphalan and prednisone plus thalidomide or placebo in elderly patients with multiple myeloma. Blood 2010a; 116: 1405-1412. 
Waage A, Palumbo A, Hulin C, Beksac M, Fayers P, Mary JY, Bringhen S, Sonneveld P, Wijermans P, Facon T. MP versus MPT for previously untreated elderly patients with multiple myeloma: A meta analysis of survival of 1682 individual patient data from 6 randomized clinical trials. Haematologica 2010b; 95 : 235 (abstr. 0567).

Wahlin A, Eriksson M, Hultin M. Relation between harvest success and outcome after autologus peripheral blood stem cell transplantation in multiple myeloma. Eur J Haematol 2004; 73: 263-288.

Wang M, Giralt S, Delasalle K, Handy B, Alexanian R. Bortezomib in combination with thalidomidedexamethasone for previously untreated multiple myeloma. Hematology 2007; 12: 235-239.

Watts MJ, Sullivan AM, Jamieson E, Pearce R, Fielding A, Devereux S, Goldstone AH, Linch DC. Progenitor cell mobilization after low-dose cyclophosphamide and G-CSF: an analysis of progenitor cell quality and factors predicting for these parameters in 101 pre-treated patients with malignant lymphoma. J Clin Oncol 1997; 15:535-546.

Weaver CH, Zhen B, Schwartzberg LS, Leff R, Magee M, Geier L, Deaton K, Lewkow L, Buckner CD. Phase I-II evaluation of rapid sequence tandem high-dose melphalan with peripheral blood stem cell support in patients with multiple myeloma. Blood 1998; 22: 245-251.

Weber DM, Rankin K, Gavino M, Delasalle K, Alexanian R. Thalidomide alone or with dexamethasone for previously untreated multiple myeloma. J Clin Oncol 2003; 21: 16-19.

Weber DM, Chen C, Niesvizky R, Wang M, Belch A, Stadtmauer EA, Siegel D, Borrello I, Rajkumar SV, Chanan-Khan AA, Lonial S, Yu Z, Patin J, Olesnyckyj M, Zeldis JB, Knight RD; Multiple Myeloma (009) Study Investigators. Lenalidomide plus dexamethasone for relapsed multiple myeloma in North America. N Engl Med 2007; 21: 2133-2142.

Wuchter P, Ran D, Bruckner T, Schmitt T, Witzens-Harig M, Neben K, Goldschmidt H, Ho AD. Poor mobilization of hematopoietic stem cells - definitions, incidence, risk factors and impact on outcome of autologous transplantation. Biol Blood Marrow Transplant 1210; 6: 490-499.

www.cancerregistry. fi

Zamboni WC. Pharmacokinetics of pegfilgrastim. Pharmacother 2003; 23: 9-14.

Zent CS, Wilson CS, Tricot G, Jagannath S, Siegel D, Desikan KR, Munshi N, Bracy D, Barlogie B, Butch AW. Oligoclonal protein bands and isotype switching in multiple myeloma treated with high-dose therapy and hematopoietic cell transplantation. Blood 1998; 91: 2518-2523.

Zhou P, Zhang Y, Martinez C, Kalakonda N, Nimer SD, Comenzo RL. Melphalan-mobilized blood stem cell components contain minimal clonotypic myeloma cell contamination. Blood 2003; 102:477-479. 